U. S. DEPARTMENT OF AGRICULTURE.

\section{s}

531

. $\mathrm{T} 8$
OFFIOE OF EXPERIMENT STATIONS-BULLETIN NO. 127.

A. C. TRUE, Director.

\title{
INSTRUCTION IN AGRONOIY AT SOME AGRICULTURAL COLLEGES.
}

A. C. TRUE and D. J. OROSBY.

WASHINGTON:

GOVERNMENT PRINTING OFFICE.

19.03. 


$$
\gamma
$$






U. S. DEPARTMENT OF AGRICULTURE. OFFICE OF EXPERIMENT STATIONS-BULLETIN N0. 127.

A. C. TRUE, Director.

INSTRUCTION IN AGRONONY AT SOIE AGRICULTURAL COLLEGES.

B Y

A. C. TRUF and D. J. OROSBY.

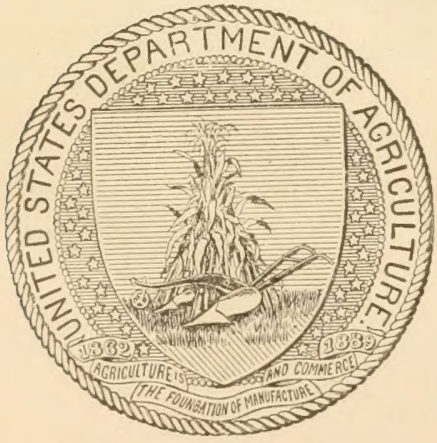

WASHINGTON :

$$
1903 .
$$




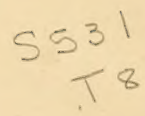

\section{OFFICE OF EXPERIMENT STATIONS.}
A. C. Tree, Ph. D.-Director.
E. W. Allen, Ph. D.-Assistant Director and Editor of Experiment Station Record.
W. H. BeAL-Chief of Editorial Division.
C. E. JoHnston-Chief Clerk.

EDITORIAL DEPARTMENTS.

E. W. Allex, Ph. D., and H. W. LAwsox-Chemistry, Dairy Farming, and Dairying. W. H. BeAL-Agricultural Physics and Engineering.

Walter H. Evans, Ph. D. - Botany and Diseases of Plants.

C. F. LAngworthy, Ph. D.-Foods and Animal Production.

J. I. Schulte-Field Crops.

E. V. Wilcox, Ph. D.-Entomolog!y and Veterinary Science.

C. B. Sмiтн-Horticulture.

D. J. Crosby-Agricultural Institutions. 


\section{LETTER OF TRANSMITTAL.}

\section{U. S. Department of Agriculture, Office of Experiment Stations, Washington, D. C., May 18, 1903.}

Sra: I have the honor to transmit herewith a report on courses in agronomy in several agricultural colleges. There is now considerable activity in our agricultural colleges in developing and strengthening the courses of instruction in this division of the science of agriculture. The report has been prepared at the suggestion of the committee on methods of teaching agriculture of the Association of American Agricultural Colleges and Experiment Stations, and is an outcome of the work of that committee. I feel sure that such a comparative presentation of courses actually being given in some of our colleges will aid in the further development and strengthening of this line of work in other institutions, and I therefore recommend the publication of the report as Bulletin 127 of this Office.

The illustrations have been carefully selected from a large number furnished by the colleges, and are intended to show distinctive features of the equipment for instruction in agronomy at the institutions represented in the bulletin.

Respectfully,

Hon. James WiLson,
A. C. True,

Director. 



\section{(1) VTEMTS}

i'age.

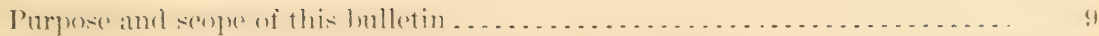

Work of the committee on methods of teaching amriculture . . . . . . . . . . 11

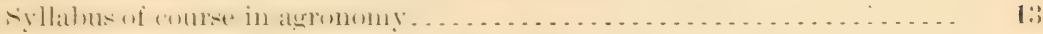

Outline for a course of lectures or a text-book on agronomy . . . . . . . . It;

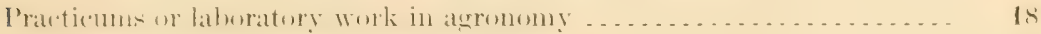

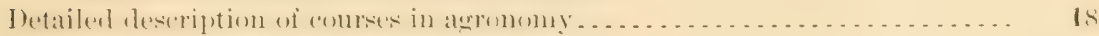

Alabama Polytechnic Institute . . . . . . . . . . . . . . . . . . . . .

Exhibit No. 1.- Examinations in agronomy ................. 21

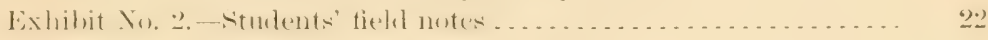

The College of Agriculture of the University of Illinois . . . . . . . . . . 2:;

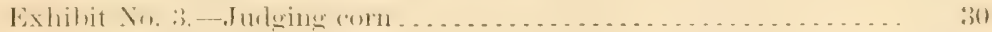

Exhibit No. 4.-Students' laboratory blanks in soil physics ........ :3)

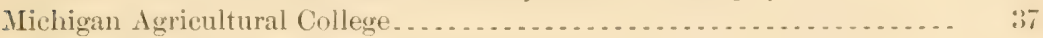

Exhibit No. 5.- A few of the practicums in agronomy .......... 42.

Exhibit No. 6. - Examination questions in soils and erops... . . . . . 47

College of Agriculture of the University of Minnesota . . . . . . . . . . . 4 .

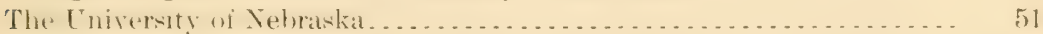

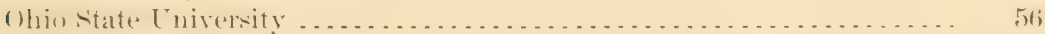

Fxhibit No. 7.-Laboratory work in the elementary course in soils.. 5:1

Exhibit No. 8.-Detailed schedule of laboratory work _......... .

Exhibit No. 9.-Examination in elementary course in farn crops.... T(

Exhibit No. 10. - List of laboratory or field practicums in elementary

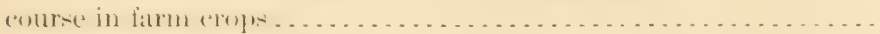

The Agricultural Institute of the University of (iittingen ............

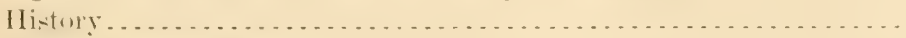

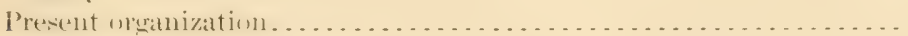

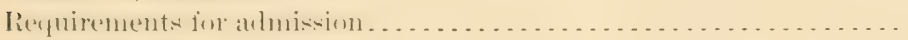

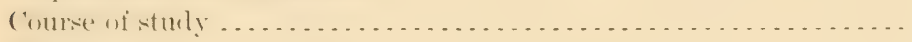

Methuls of instrumtion . . . . . . . . . . . . . . . . . . . . . . . .

Instrution in aternum . . . . . . . . . . . . . . . . . . . . . . 71

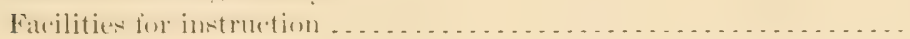





\section{ILLUSTRATIONS.}

\section{PIAT'TES.}

PLATE I. University of Illinois, bird's-eye view of agricultural building an:1 experiment tiede . . . . . . . . . . . . . . . . . . .

Page.

II. Fig. 1.-University of Illinois, class in agronomy studying root development of corn. Fig. 2.-University of Illinois, class

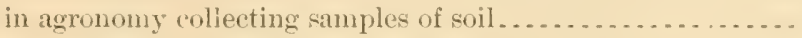

III. Fig. 1.-University of Illinois, soil fertility laboratory for analysis and synthesis of soils and fertilizers. Fig. 2.-University of Illinois, class in agronomy in pot culture laboratory . . -

IV. Fig. 1.-University of Illinois, soil physies laboratury. Fig. 2.University of Illinois, farm crops seed laboratory . . . . . . . . .

V. Michigan Agricultural College, Agricultural Hall ........ . . . . .

V'I. Fig. 1.-Michigan Agricultural College, students making mechanical analyses of soils. Fig. 2.-Michigan Agrieultural College, soils laboratory and class room ................

VII. Fig. 1.-University of Minnesota, Dairy Hall. Fig. 2.-University of Minnesota, emasculating and cross pollinating wheat..

VIII. Fig. 1.-University of Minnesota, Centgener thrashing machine and fanning-mill separator in use in the field crop nursery. lïg. 2.-University of Minnesota, machine for planting grain

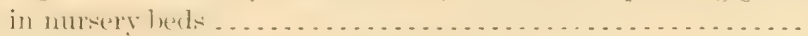

IX. University of Nebraska, agricultural building . . . . . . . . . . .

X. Fig. 1.-University of Nebraska, field crops laboratory, students judging seed corm. Fig. 2.-University of Nebraska, soils laluratory.

XI. liig. 1.-University of Neloraska, apparatus for making determinations of soil moisture. Fig. 2.-University of Teloraska,

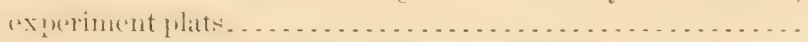

XII. Fig. 1.-University of Nebraska, seed laboratory. Fig. 2.-University of Nebraska, a corner in the seed storeroom ........

XII. Ohio State University, Townshend Hall ... . . . . . . . . . . . . .

XIV. Fig. 1.-Ohio State University, mechanical analysis of soil. Fig. 2.-Ohio State University, torsion balance used in soil phys-

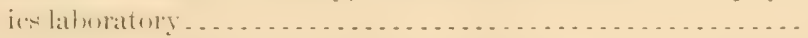

XV. Güttingen Agricultural Institute, main building............ XVI. Fig. 1.-Göttirgen Agricultural Institute, looking sontheast. Fig. 2.-Göttingen Agricultural Institute, looking northeast from institute buildings across the experiment plats....... XVII. Güttingen Agricultural Institute, greenhouse .............. 


\section{TEXT FIGURES.}

FIr. 1. Centrifuge, shaker, and electric motor used in mechanical analysis of

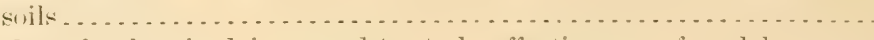

․ Tubes of galvanized iron used to study effectiveness of mulches upon

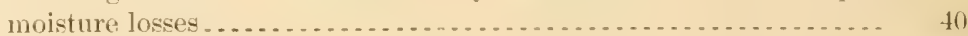

:. King's aspirator to determine the effective size of soil grains . . . . . . 41

4. Apparatus used to study the movement of air through soils ........ . . 4:

5. Apparatus used to study percolation of water through soils ........ 44

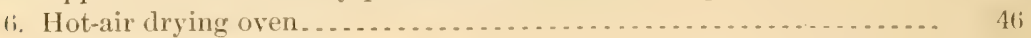

7. Centrifugal seerl-grading mathine . . . . . . . . . . . . . . . 51

s. Movable soil thermometer . . . . . . . . . . . . . . . . . . . . . . . .

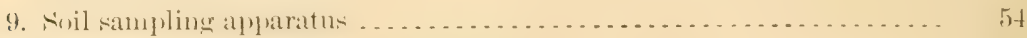

10. Apparatus for determining specific gravity of soils . ............. (it)

11. Determination of volume weight, apparent specific gravity, and poros-

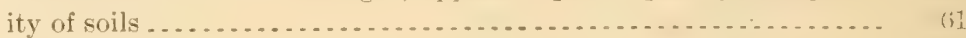

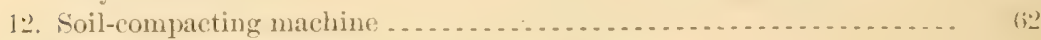

1:3. Determining the power of soils to retain moisture ............. (i:;

14. Rate of percolation of water through soils ................... (it

15. Apparatus to determine the rate of flow of air through soils......... (i5)

1ti. Soil tubes for showing the effect of mulches on evaporation of water from wils. . . . . . . . . . . . . . . . . . . . . . . . . . . . . . (i.)

17. Determining the power of air-dry soils to alsorb moisture from the sii- $\quad$ liti

18. Measuring eapillarity in soils................................. (it

19. Apparatus for testing the adhesiveness of soils ................. (is

20. Card's apparatus for testing the adhesiveness of soils........... (i,

21. Apparatus for taking soil samples . .........................

22. Plan of experiment grounds at Göttingen Agricultural Institute...... \$; 


\section{INSTRICTION IN ICROMOMIY IT SOMIE .MRICTI: TURAL COLLEGES.}

\section{PURPOSE AND SCOPE OF THIS BULLETIN.}

This bulletin is based on the reports of the rommittere on methods

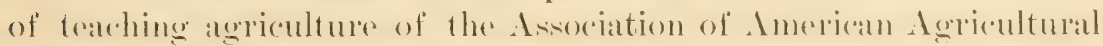
Colleges and Experiment Stations and on funther inquiries made by Whe ()thie of Experiment stations. It is intended to supplement the work of the committere in collating detailed information regalleding instruction in agronomy. The status of that work at the time the committee made its sixth report" is indicated hy the following paragraph from that report:

After consultation with the instructors in agriculture in the different colleges, it has seemed well for your committee to undertake to present in some detail information regarding the courses in agriculture and the facilities for instruetion in this subject in our colleges. It is especially desirable to put on record data regarding distinctive features of these conreses and the materials for denometration and illustration alreadv existing in different intitutions. Your committee has, therefore, undertaken during the prevent year fo collate such information rexarding the contre in agronomy. Considerable material has already been accumulated, but some time must elapse before it will be in form for publication. Your committee therefore asks that it may be granted leave to print its report on agronomy in our agricultural colleges, in whole or in part, in the next proceedings of this association, and be given authority to negrotiate with the (oflice of Experiment stations for the separate pulplication of its detailed report on this subject.

Authority to publish its detailed report in aceordanee with the alowe reguest was granted the committee, which, howerer, was not able to prepare the material in time for printing in the proseseding of the association. This ()the undertook, therefore, to complete the report and publish it.

Suberuent inquiries on the part of the Office of Experiment Stations by correspondence, by member's of the Othice fores maling risite of inspection to the anricultural experiment stations, and hy a sperdial ofticer sent 10 vinit a number of the colleges. showed that while many

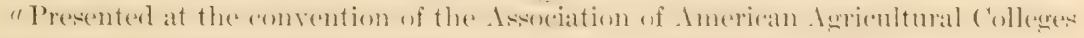
and Experiment Stations in Washington, D. C., November 12-14, 1901. 
of the agricultural colleges hare madr some progress in differentiating agronomy from the other subdivisions of agrieulture, only a few have dereloped well-balanced courses in agromomy, with laboratory and field prateticums in which spectal forms for scoring different eropes and specially devised appatratus are used. It seon hecame apparent that it would not be feasible to publish within the seope of a Department bulletin detailed information regareling the consers of study in all the agrieultural rolleges in the Lnited states and. furthermore, that sueh publication would not at present be desirable breatuse (1) it would include a number of institutions that have not get been able or have not found it desirable to differentiate agronomy from the gemeral subjeret of agriculture: and ( $(2)$ it would include some rolleges that are just reorganizing their courses of instruction with referenes to the subdisisions of agriculture, including agronomy. and are not now in a position to make a showing commensurate with their facilities for instruction.

It has been decided, therefore. to include in this bulletin (1) a brief review of the work of the committere on methods of teathing agriceulture. together with such excerpts from the reports of that committer a: latre a bearing on the present discusions and (2) detailed deseriptions of eourses in atgronomy in seven agricultural colleges -six in the Lnited states and one in Eurepese. The institutions selfected include (1) two collegere not commereded with mivereities-Alathama in the South and Nichigan in the North; (:2) two university colleges having

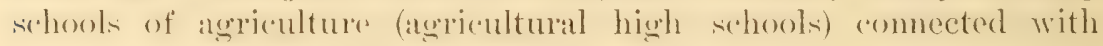

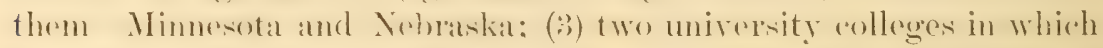
no provision for preparatory work is made Illinois and (ohios and (l) a tuiversity eollege in (remany the Aericultural Institute of the University of Göttingen.

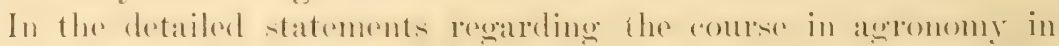

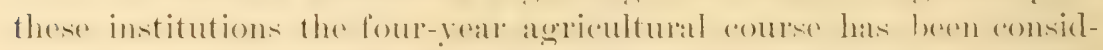

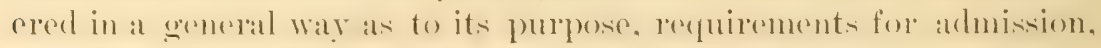

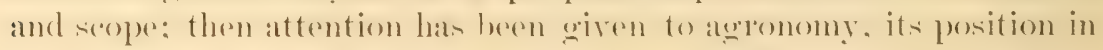
the four-yatr course. preparation for it seretred by means of previous work in botany and whemisty. its seope and the method of presentattion to the students. Under this last head an account has been given

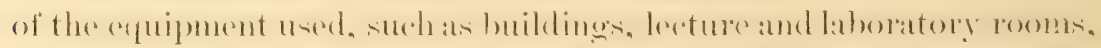

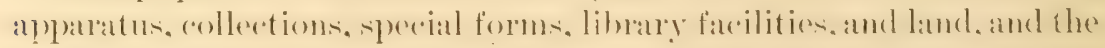
leating features of this arpuipment have been illustrated. In the prene-

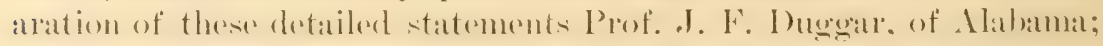
Dr. C. G. Hopkins, of Illinois; Prof. J. A. Jeffrey, of Michigan;

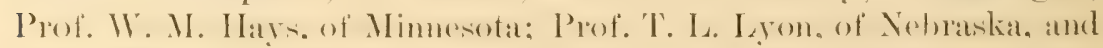
Prof. W. D. Gibbs, of Texas (formerly of Ohio), have rendered viluable assistance. 


\section{WORK OF THE COMMITTEE ON METHODS OF TEACHING AGRICULTURE.}

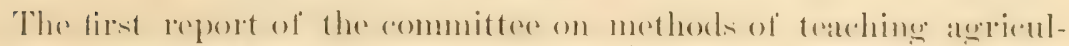

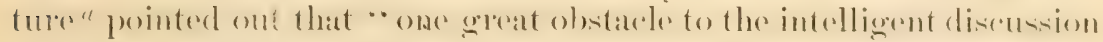

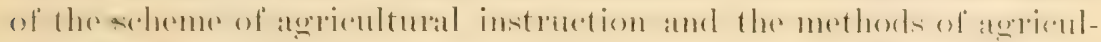

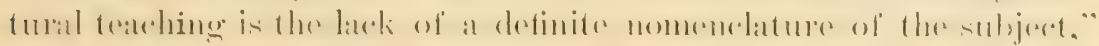
and suggested "for the consideration of the association a tentative scheme for the division of what is commonly designated agrienteres

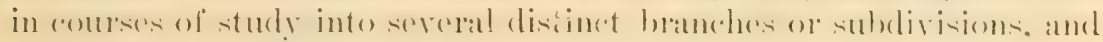
for giving each of these branches a definite name, as follows:

1. Agronomy, or agrieulture f Climate, soils, fertilizers, and crops(techmical). plant production.

2. 'Zootechny, or animal in- I Animal physiology and animal produedustry. tion.

3. Agrotechny, or agrieul-f Agricultural industries, e. g., dairying, tural technology.

Agrenlture t. Rural engineering, farm sugar making.

Roads, drains, irrigation systems, furm equipment. buillings, etc.

5. Rural economy or farm management.

(ieneral policy of farm management, rural law, agricultural bookkeeping, ete.

In its second report" the eommitter first undertook "to determine the ereneral relation of a course in technieal acriculture to the other combes of study which should be connected with this to form a fouryear course in an agricultural college," adopting ats a working hasis the following pertion of the report of the rommitter on cutranes requirements, courses of study, and degrees: $c$

In the judgment of your committee, it is not too much to require the equivalent of fifteen hours per week of recitations and lectures, togrether with ten hours per week of laboratory work, or practicums, including the time devoted to military science and drill. Upon this basis the above-mentioned general studies should be assigned a relative importance, approximately as follows:

\begin{tabular}{|c|c|c|c|}
\hline \multicolumn{3}{|c|}{ IIours. 1} & Hours. \\
\hline Algebra... . . . . . . . . . & 75 & Modern languages . . . . . . . . . . & 340 \\
\hline 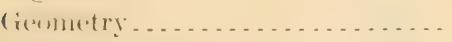 & 40 & 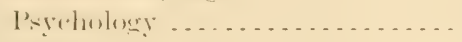 & 60 \\
\hline Triqunnmuntry . . . . . . . . . . . . & 40 & Ethies or hogir . . . . . & 10 \\
\hline Physicy (class-room work) ....... & 75 & Political economy .............. & 60 \\
\hline Physics (laboratory work) ...... & 75 & General history ............... & 80 \\
\hline Chemistry (class-room work) .... & 75 & Constitutional law . . . . . . . & 50 \\
\hline Chemistry (laboratory work) .... & 75 & & \\
\hline English..................... & 200 & & \\
\hline
\end{tabular}

"Report presented to the Association of Ameriean Arricultural Colleges and Experiment Stations at the convention held in Washington, D. C., November 10-12, 1896. See U. S. Dept. Agr., Oflice of Experiment Stations Bul. 41, P. 57, and Cire. $: 32$.

"See U. S. Dept. Agr., Office of Experiment Stations Bul. 49, p. 29, and Cire. 37.

rsee U. S. Dept. Agr., Oflice of Experiment Stations Bul. 41, 1. 52. 
The total number of hours included in a four-year course, allowing fifteen hours per week for thirty-six weeks, would he 2,140; with ten hours' laboratory work, or jracticum, added, 3,600. In general terms, therefore, the foregoing general studies should comprise about two-fifths of the work required for a bachelor's degree.

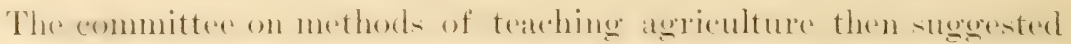

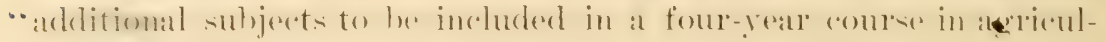
ture leading to the degree bachelor of science, "as follows:

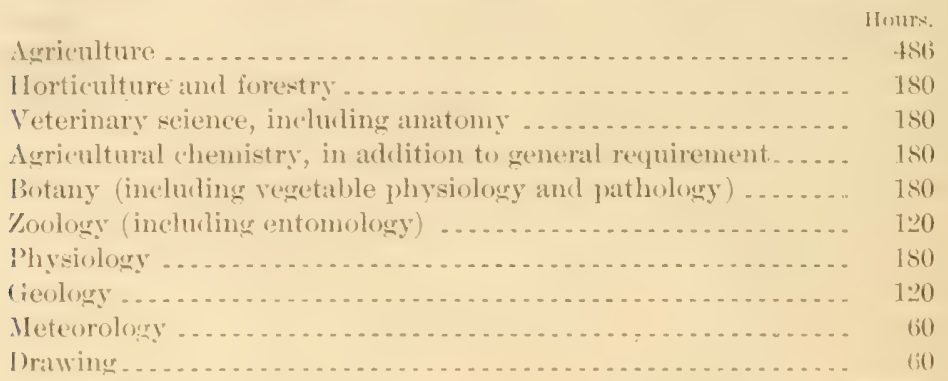

'Total . . -

$1,7+6$

Taking up), then, the subject of agriculture, the ammitter recommended the following allotments of time to its subdivisions:

Ifontrs.

1. Agronomy, or plant production ... . . . . . . . . . . . . .

2. '/ootechny, or animal industry .................... 162

i. Agrotechny, or acricultural technology .............. T2

4. Rural engineering, or farm mechanice. . . . . . . . . . . . 60

5. Rumal economics, or farm mamgement................ 60

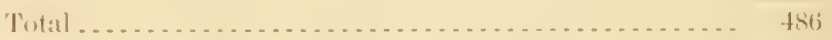

It was also ammoumeed that the committee would next take up in

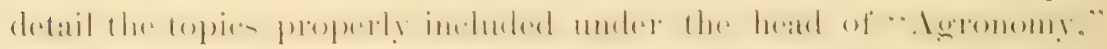

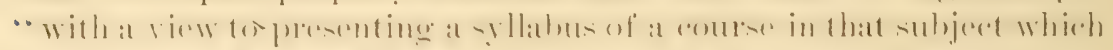

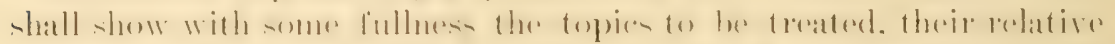

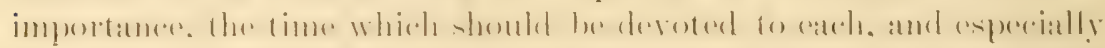

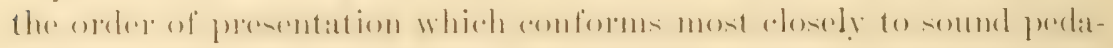
gogical prineiples." "This was done in the third report" of the committee. which was divided into three parts, as follows:

(1) A syllalus defining the limits of a course in agronomy, and stating the fopics included in agronomy in the order in which they should be presented to students, i. (n, in their logrical and pedagromical order.

(2) A series of lecture or chapter headings showing how the syllabus for agronomy may be applied in preparing a course of lectures or a text-book on this subject, covering ninety-nine class-room hours or periods of sixty minutes each, i. e., three lecture or recitation periokls a week.

(a) A series of subjects for practicums or laboratory exercises to be used in connection with the elass-room work in agronomy, and covering the thirty-three remaining hours or periods (equivalent to sixty-six hours of sixty minutes (each), assigned to the course in agronomy, i. e., one practicum per week.

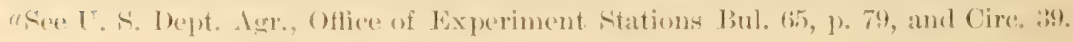


It hals been the olject of the eommittee to make such an ontline of this course as (am easily be atjusted to the requirements of institutions with different organization and environment. While the syllabus is intender to limit the range of subjects which may properly be included under agromomy, the amount of attention which shall be given to particular topics will vary according to circumstances. The series of chapters and practicums are in a measure intended simply to show a way in which the subject of anronomy may be presented in actual pratice. This is especially true of that portion of the course which relates to individual farm crops, to which attention will naturally be given according to their relative importance in different localities

\section{SYLLABUS OF COURSE IN AGRONOMY.}

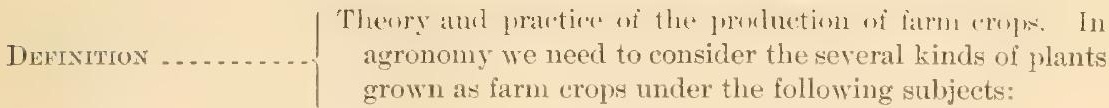

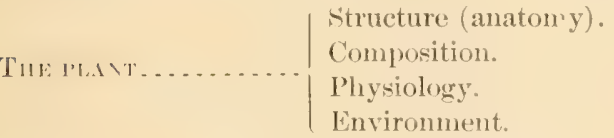

(In agriculture has for its object the alaptation of environ_ ment to the anatomy and physiology of the plants moler

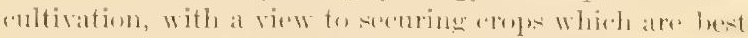
suited to the uses of man or the domestic animals.

We may conveniently begin the study of plant production by considering the general characteristicy of the environment of plants as grown in the field.

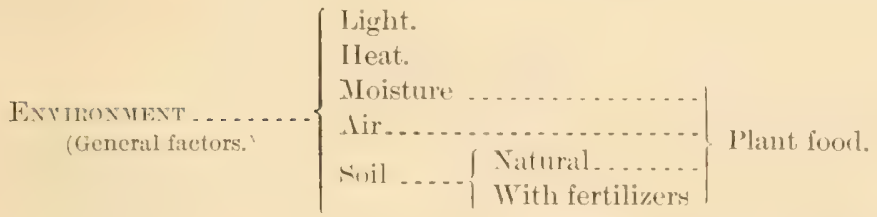

But environment may be conveniently divided according to position, as follows:

Vivilitite. . . . . . .

(Divided aceording to position.) (Chapters I III wi lexture outline page 16.)

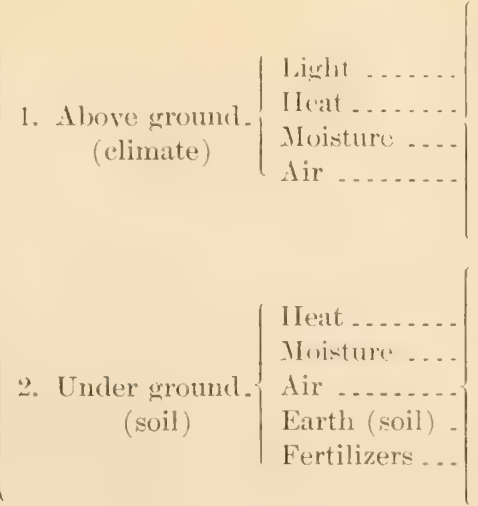

Study the relation each of these factors to plant growth, and also briefly their effects in different com binations, i. e., different climates.

P'oint ont that the relation of these factors t1) plant growth may be most clearly perceived by first considering them in their relation to each other 
Definition-Nature.

Functions.

Brief greological ontline.

Weathering of rocks.

Origin . . . . . Accumulation of organic matter.

Transformation of organic matter (nitrification and denitrification, etc.).

Additions from atmosphere.

Soll

(Chapters IV-XXXI.)
'Temperature.

dir.

Moisture

Chemical.

Properties

$-$

Physical.

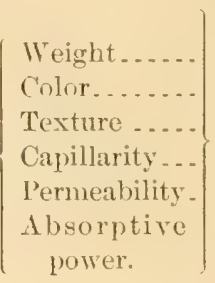

Classification of soils, on the basis of their properties.

Sources... . . . . .
Amounts . . . .

Water tahle. Il ygroscopic moisture. Rainfall. Irrigation-Methorls.

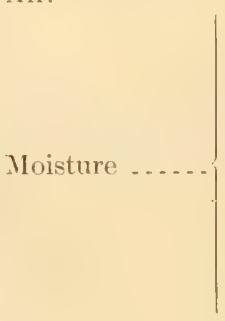

Tillage ....... Drainage ...... \{ $\begin{aligned} & \text { Purpose and effects. } \\ & \text { Methods. }\end{aligned}$

Conservation .. $\left\{\begin{array}{l}\text { I'urpose. } \\ \text { Methods. }\end{array}\right.$

Purpose and | Chemical. effects. $\quad$ Physical.

Methods. Biological.

Definition.

.

Fertilizers......

Methods
action.
Clas-
sifica-

and effects of

Chemical. Physical. Biological.

1. Aecording to constituentsa. Nitrogenous.

b. Phosphoric.

c. Potassic.

d. Other amendments.

2. According to formtion. $\begin{gathered}a . \text { Green mat- } \\ \text { nures. }\end{gathered} \mid$ Farm mab. Animal ma- nures. nures.

c. Commercial-classif y principal forms.

(Study first the general theory of fertilizers according to abore scheme and then consider in as much cletail as may he deemed desirable different kinds of fertilizers, using Schedule A.) 


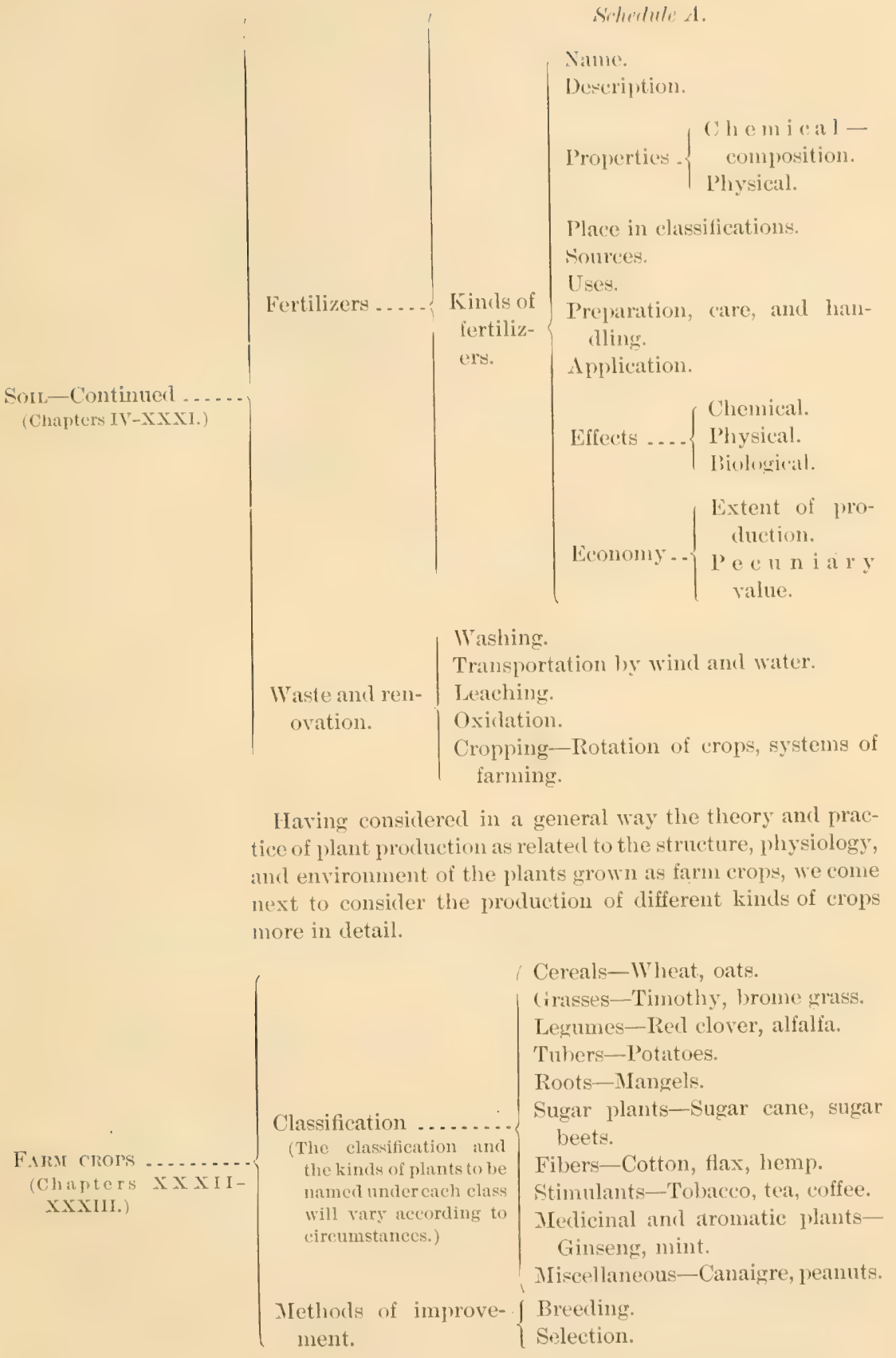


Next sturly individual farm crops according to the follow. ing scheme:

Name.

| Place in rlassification.

structure,

Composition.

Physiology.

Botanical relations.

Varieties .......... Classification.

Geographical distribution.

INDIVIDTA FAR

(CRO) 1 s.

(Chapters XXXI-IXI.)

(The erons to bestudier will vary according to locality ind other eircumstances.)
Ilarvestingr.

['reservation.

I sises.

I'reparation for use.

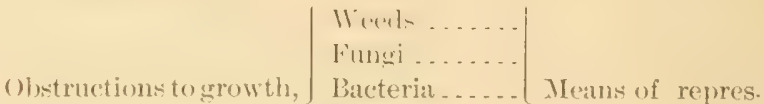

preservation, or use.

Prorluction.

Marketing.

Ilistory.

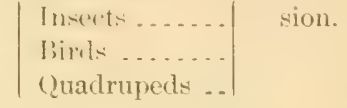

Choice ans preparation of soil.

Manuring.

Seeds (or other parts of plants used for planting)-Selectionamount-treatment.

Planting.

Cultivating.

Place in rotation.

\section{OUTLINE FOR A COURSE OF LECTURES OR A TEXT-BOOK ON AGRONOMY.}

[The lectures are intended to cover 99 hours.]

Chapter I. fieneras cimatic comditions.

II. Plant food and erowth.

III. Air as a somere of plant food.

IV. The nature, functions, origin, and wasting of soils.

V. Properties of soils, chemical and physical. Classifications, texture, composition, and kinds of soils.

V1. Physics of soils as related to plant growth (capillarity, solution, diffusion, and osmosis).

VI. Soil temperature.

VIII. Relation of air to sill.

I. Soil water.

X. Irrigation.

XI. Improvement of soil through drainage.

Xil. Drainage methods.

XIII. Conservation of soil moisture.

XIV. Physical effects of tillage.

$\mathrm{AV}$. Chemical and biological effects of tillage. 
Chapter XVI. Methods of tillage.

XVII. Methods of tillage.

XYII. Fertilizer-Methorls and effects of action.

XIX. Fertilizers-Classification by constituents and form.

XX. Sources and uses of nitrogen.

XX1. Sources and uses of phosphoric acicl.

XXII. Sources and uses of potash.

XXIII. Soures and wes of other amendments.

XXIV. Practical advice on the we of commercial fertilizers.

XXY. II tumus and green manuring.

XXYl. Animal manures. General statements.

XXVIl. Manures produced from various animals.

XXYII. Care, preservation, and application of manure.

XIIX. Iraste and renovation of soils.

XXY. Rotation of crops-General statements.

XXXI. Rotation of crops-Systems of farming.

XXXII. Farm crops-Classification, production; reasons for choice.

XXXIII. Improvement of farm crops.

XXXIV. Wheat-Structure, composition, and varieties.

XXXY. Wheat-Culture, harvesting, and preservation.

XXYVI. Wheat--Obstructions to growth, preservation, and use.

XXXVII. Wheat-Production, marketing, history.

IXXVIII. Corn.

IXXIX. Corn.

XI. Corn.

ILI. Corn.

XLII. Rice.

XIIII. Oats.

XLIV. Barley and rye.

XLY. Girasses.

XLVI. Grasses.

XLVII. Clovers.

SIVIII. Pastures.

XLIX. Silage.

L. Forage crops:

L.I. Potatoes.

LII. Potatoes.

LIII. Root crops-Mancels, beets, turnips.

LIV. Sugar plants-Sugar beets.

IN. Sugar plants-Cane, sorghum, ete.

I.Y. Fiber plants-Cotton.

IVII. Fiber plants-Cotton.

I.VIII. Fiber plants-Flax, hemp, jute, ramie, sival, ete.

LIX. Stimulants-Tobaceo, tea, coffee.

LX. Medicinal and aromatic plants.

IXI. Miscellaneous plants-Buckwheat, broom corn, peanuts, hops, canaigre, etc.

[The order of discussion of the different crops will be the same as in the case of wheat. The details to be given for each crop will vary with the importance of the crop in any region:]

$$
267 \div-\mathrm{N}(1,125-11: 3-2
$$




\section{PRACTICUMS OR LABORATORY WORK IN AGRONOMY.}

[The practicums are intended to cover 33 laboratory periods, i. e., 66 hours.]

1. Determination of specific gravity of soils.

2. Determination of volume weight of soils.

3. The power of retaining moisture in the soil in its highest degree of looseness.

4. The power of retaining moisture in the soil when compacted.

5. Rate of percolation of water through soils.

6. Rate of percolation of air through soils.

7. Effect of mulches upon evaporation of water from suils.

8. Behavior of soils toward gases.

9. Capillary attraction in soils.

10. Determination of cohesion in soils.

11. Mechanical analysis of soils.

12. Mechanical analy'sis of soils.

13. Study of root systems of principal crops.

14. Study of root systems of principal crops.

15. Study of root systems of principal crops.

16. Study of varieties of corn in field.

17. Scoring ears of corm.

18. Study of effect of fertilizers on one or more crops in fall.

19. Study of effect of fertilizers on one or more crops in early spring.

20. Study of effect of fertilizers on one or more crops near harvest.

21. Study of varieries of wheat in sheaf and by sample.

22. Study of varieties of wheat in sheaf and by sample.

23. Study of varieties of wheat in field.

24. Study of varieties of oats or other grain in sheaf and by sample.

25. Study of varieties of oats or other grain in field.

26. Study of varieties of potatoes by sample.

27. Study of rarieties of potatoes in field.

28. Study of varieties of grasses and forage crops in field in fall.

29. Study of varieties of grasses and forage crops in field in early spring.

30. Study of rarieties of grassey and forage crops near harrest in field.

31. Study of varieties of grasses and forage crops by sample and preparation of abstracts of station experiments on climatic and soil conditions and upon quality and yield.

32. Study of varieties of grasses and forage crops hy sample and preparation of abstracts of station experiments on climatic and soil conditions and upon quality and yield.

33. Study of varieties of grasses and forage crops by sample and preparation of abstratets of station experiments on climatic and soil conclitions and upon quality and yield.

\section{DETAILED DESCRIPTION OF COURSES IN AGRONOMY.}

\section{ALABAIVA POLYTECHNIC INSTITUTE}

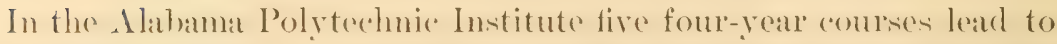

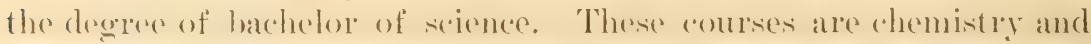

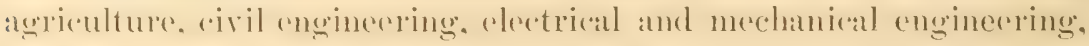

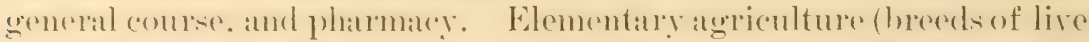

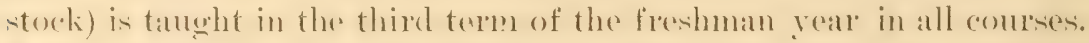

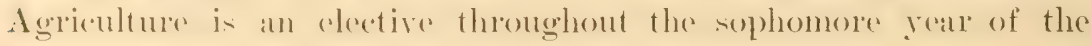




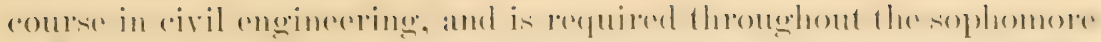

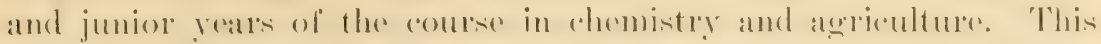

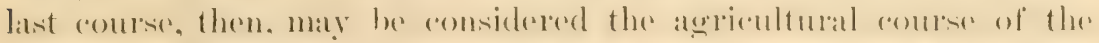

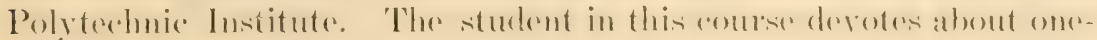
fifth of his time to English, history and economies; almot two-fifthe

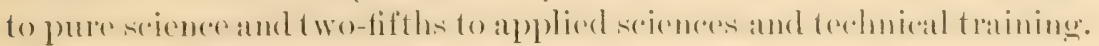

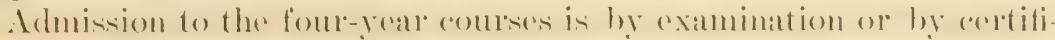

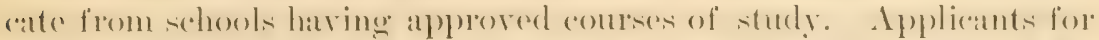

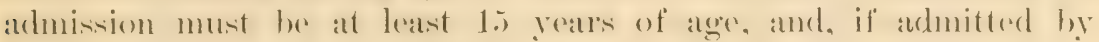
examination, must be qualified to pase satisfactory examinations in (1) geography and history of the Lniterl states: (2) Enghish, imbluding

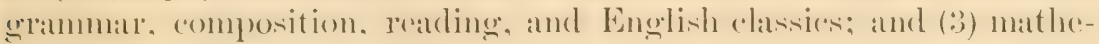
maties. including arithmetic and algebra thromgh yuadrat ie entations. ".Those applieants who desire to continue the study of Latin should he qualified to patsis a satisfatery examination in Latin grammar and the first two books of (atsir in addition to the above subjerts."

The entres in agronomy is given during the second and third torms

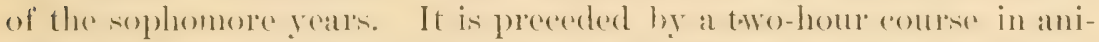
mal hushandry during the third term of the freshman year at two-hour course in dairying during the first term of the sophemore year. and at three-hour course of lecetures and one lathoratory exereine per week in general chemistry during the first term of the sophemore year, and is followed by aourses in systematic and stometural botany (lectures and laboratory), plant physiology, and agricultural chemistry.

"The course in agricultural chemistry is geiven in the senion" year and "consists of lecetures on chemistry in its application to angreoulture (two per week. during second and third terms), and includes a thorough discussion of the origin, composition, and classifieation of soils, the composition and growth of plants, the soureses of plant food and how ohtaines, the improrement of soils, the manufacture and use of ferptilizers, the chemical principles involved in the rotetion of erengs, the feeding of live stock, and the various eperations arried on by the intelligent and successful agrienturist." During the same periods the students do laboratory work in ruantitative analysis six hours pere week. The principal referenee books nsed in agricultural chemistry

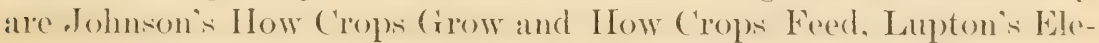
mentary Principles of scientific I grrieulture, Johnson and Cameronis Elements of Agricultural Chemistry, storer"s Agriculture, scientific

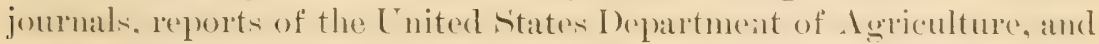
the bulletins and reports of the various domestic and foreign algricultural departments and stations. "The lathorateries. which are opeen from ! a. m. to. 5 p. m. during six days in the week, are amply supplied with erergthing necessary for instrution in shemieal manipulation." Instruetion in agremomy is giron by the profersor of agriendture. "In the second term of the sophomore yeat the following sulpjects are 
studied: Soils-chemical and physical properties, defects, and means of improvement; the control of water, including means of conserving moisture in times of drought: terracing. underdrainage, and open and hillside ditches; ohjects and methods of cultivation; agricultural implements; rotation of crops: and improrement of plants by arossing, selection, and culture. The thirl term of the sophomore year is devoted to the staple (rops produced in Alabama, to forage plants adapted to the South, and to plants valuahle for the renoration of soils. The more important crops are treated with reference to varioties, soil and fertilizer requirements, methods of planting and ("ultivating, and uses." In all classes there are mid-term examinations and term-end examinations.

Two hours per week are devoted to lectures, in which the number of students ranges from 10 to 25 , and two aftermoons per week are given up to farm practice, during which time the clasises are divided into sections of from is to s students. I part of the firld work is conducted hy the profescor of agriculture and a part is in chatge of an assistant in agriculture:

In every elasis the student is encouraged to independent thought on agricultural problems rather than to depend on " rules of thumb," so that he may be prepared to adapt his practice in after years to chamged conditions of soil. climate, "apital, markete ete. An eflort is made to keep before the student the difference between the widely appliables principles on which erery rational system of farming rests and the details that vary with changing conditions. The conditions of soil, rlimate, ete. prevailing in ditlerent parts of Alabama are kept constantly in view. As far as limited time allows, attention is dieceted to adericaltural literature now aceumulating so rapidly in this and in foreign combtries, to the ond that in future rears the student may know where and how to seek the information that he may need.

Anong the reference books and other literature used liy students in agromomy are Soils and ('rops of the Farm, Morrew and Hunt; Forage Plants. Shaw: The Fertility of the Soil, Roherts; Corn C'ulture, Plumb: The Physies of Agrieulture, King: other recent American works on agriculture; bulletins of the I'nited States Department of Agriculture and of the experiment stations in the diflerent states, and a number of farm journals.

Leetures in agronomy are giren in the main building in a chass room provided with chairs and arm rests for wo students, two sides of the reom being oceupied by eases for specimens. Three small harns and a gin reom serve partly as laboratories for students when engaged in indere work. Platson the experiment-station farm showing the effect of fertilizers. methods of "ulture, atc... and collections of varieties are used as object lessons for students. 
The following exhithits will give an idea of the nature and seope of

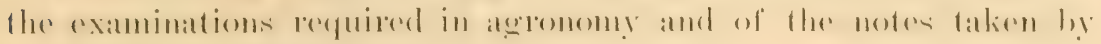
students in the field:

Exmизт No. 1.

\section{EXAMINATIONS IN AGRONOMY.}

Examination in begiming agronom!, second tem, sophomore yeur.

I. (a) In what kind of weather and at what time of year can wetter soils be safely plowed than under other conditions? Explain. (b) Does a elay or a sandy soil contain more moisture when plants begin to wilt? Explain.

II. ( $($ ) Discuss the importance or nonimportance of the hygroseopic power of mils. (l, Disctes the praticability or otherwise of determining what fertilizers to apply by an analysis of the soil.

III. Discuss capillarity in the soil (direction of movement, favorable conditions, effect of slight min after long drought, etc.).

IV. Fxplain fully the effect of cultivation on the moisture in the different layers of soil.

V. Discuss fully the size and use of the roller and its effects on the soil, and state conditions when it should be used.

VI. Discuss the general direction for ditches, methods of making junctions, and draw cross section illustrating ( $($ ) carrying eanal, (b) shallow hillside ditches, $(c)$ open drainage ditch.

VII. (a) Discuss grades for open tile drains. (b) Make drawing of homemade level and show how used $(c)$ in making a terrace and $(d)$. in giving a uniform grade to bottom of a ditch.

VIII. Irrigation. (a) Give three commonest sources of water in order of cheapness. (b) What advantages in furrow system over flooding system? (c) What levels would head ditches follow and how would nature of soil influence the grade of the rows?

IX. Discuss fall versus spring plowing in the Gulf states.

X. $(a)$ Give a three-year rotation for cotton farm, showing why the crops should follow in the order stated. (b) Outline a rotation that will put half the land in cotton each year. (c) Construct a five-year rotation for a mixed cotton and stock farm in the central prairie region of Alabama, stating when each crop is planted.

\section{Examination in agromomy (forage plants), third term, sophliomore year.}

1. (a.) What advantages has fall sowing of grasses and clovers over spring sowing? (!) Mention three legumes that can not be sown in fall and give best month for sowing each of the three.

II. (a) Compare early versus late cutting of hay. (b) When eut red clover?

III. Gire means of distinguishing small grains of oats, wheat, larley, and rye.

IV. Discuss Texas blue grass.

Y. Discuss redtop.

VI. Discuss white clover.

VII. Discuss culture and uses of rape plant.

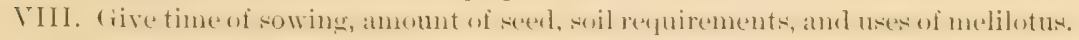

IX. Velvet beans-uses and culture.

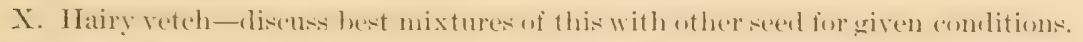


Exmimit No. 2.

\section{S'TUDENTS' FIELD NOTES.}

Notes on rarieties of com

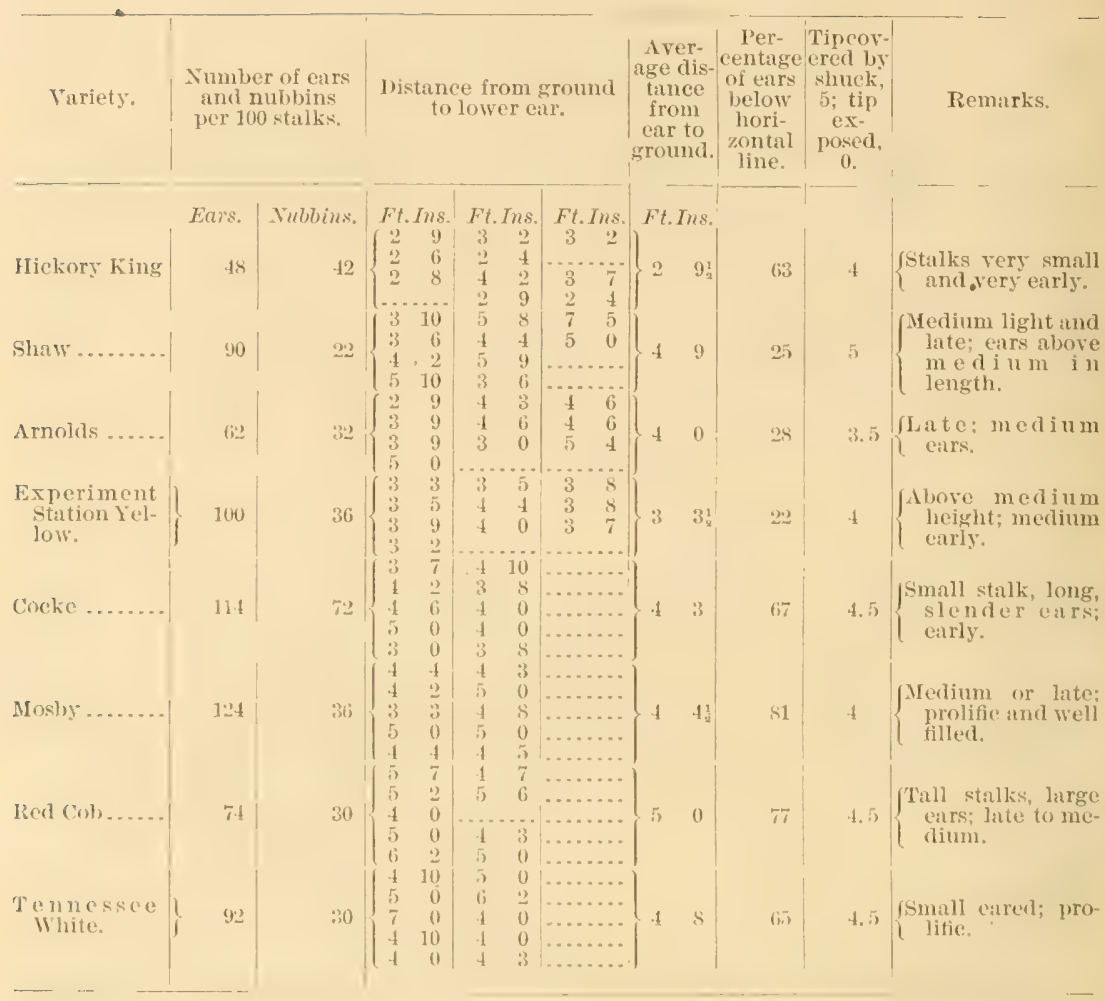

Notes on rarieties of cottom.

Cotton. Field No. (Row) 6.

Wariety: Dickson Cluster.

I. Bolls, position. \{Cluster, semicluster, noncluster: Cluster.

Terminal or nonterminal,

II. Stalk.

Base limbs .. $\left\{\begin{array}{l}\text { Number: } 2 \text { to } 5 \text {, generally } 2 \text { to } 3 . \\ \text { Lenth: Medium. }\end{array}\right.$

Internodes: Merlinm.

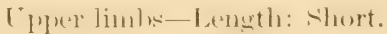

Compactness: Erect.

Height: Medium.

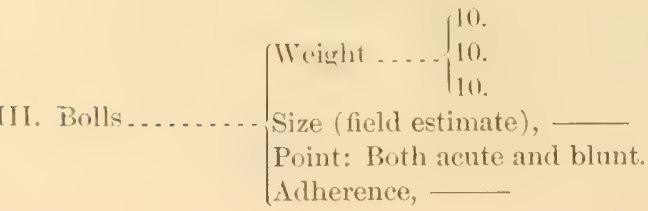




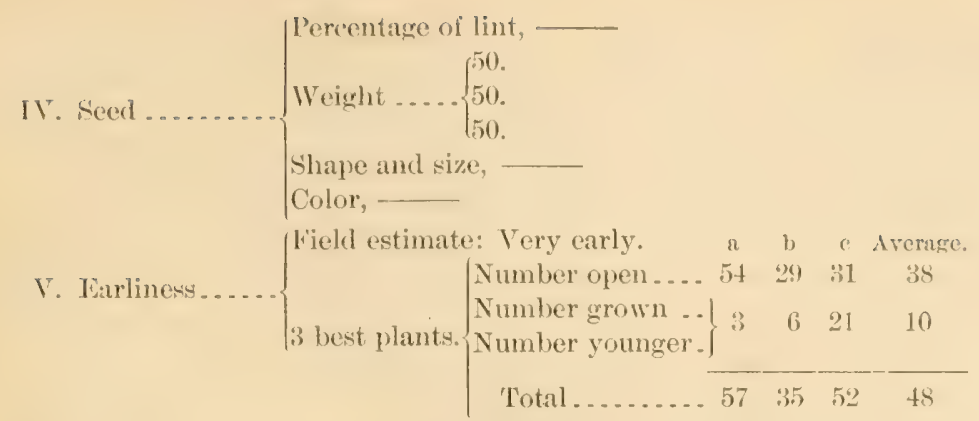

Percentage of bolls open, 79 .

VI. Prolifieacy .... \{ $\begin{aligned} & \text { Selected plants (field estimate); percentage, } 100 . \\ & 3 \text { best plants (office), }\end{aligned}$

VII. Lint (field estimate),

\section{THE COLLEGE OF AGRICULTURE OF THE UNIVERSITY OF ILLINOIS.}

The colleger of acriculture is one of the six colleges of the L niversity of Illinois. Candidates for admiscion to the college of agrianlture are refuired to have the same number of high school ededits ats andidates for admission to other colleges of the university.

This number is foredits at the present time, but it will be increased to t.2 credits in 1905. By the term credit is meant the work in a subject eontinuoms pursued with claily receitations through one of the three terms of the high sehool rear; or, in other words, the work of bo recitation periods of forty minutes each, or. the equivalent in lahorattory or other pratice. Of the total number of credits resuired for admission, must be in English, 7 in mathematies, and ti in science and listory. For graduation from the college of agrienture, students are repuired to have ohtained 130 mirersity eredits. By the university credit is meant a clatsis period at week for one semestere andeh class period presupposing two hours preparation he the student. or the rquivalent in laboratory, shop, or tiekl pratetien. The work for te credits is preseribed as follows:

15 eredits in agronomy.

5 credits in thremmatology.

$2 \frac{1}{2}$ credits in animal husbandry.

$2 \frac{1}{2}$ credits in dairy husbandry.

8 eredits in horticulture.

15 credits in chemistry.

5 credits in geology.

Of the remaining if aredits reyuired for graduation at least $t_{2}^{1}$ must be chosen in animal hushandry or dairy hushandry as in natural his-

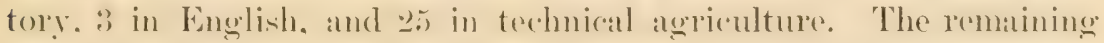
credits may be olstained from any suljects offered in the mniversity 
wheh the student is prepared to take, provided only that two years of foreign language must he taken in the mirersity if not offered for admision. A thesis is also recpuired for gaduation for which from 5 to 10 aredits will be allowed aceording to the nature of the subject.

The students in the college of agrienlture are given courses in English or other languages in the college of literature and arts: courses in chemistry, physies, geology, botany, zoology mathematices, ete., in the college of science: blatismithing, carpentry. ote.. in the college of engineering, the work of the college of agriculture being devoted to the subject of agronomy, animal hushandry, dairy hushandry, horticulture, and veterinary science. or, in other words. to the subjects in technical agriculture.

In the department of agronomy 15 courses are offered (not including the courses in farm mechanies). which are deseribed briefly in the following excerpts from the college catalogue:

The semester, the days, and the class period or periods during which each course is given, and the number of credits per semester for which the course counts are shown after each course, as follows: The semester is indieated by the Roman numerals I, II; the days, by the initial letters of the days of the week; the class period or periods (of which there are nino each day, numbered consecutively from 1 to 9 ), by Arabic figures; and the amount of credit, by Arabic figures in parentheses. For example, the abbreviations I; M., W., F.; 1 ; (3) are to be read first semester, Monday, Wednesday, and Friday, first period, three credits.

1. Drainage and irrigation.--Location of drains and irrigation conduits, leveling,

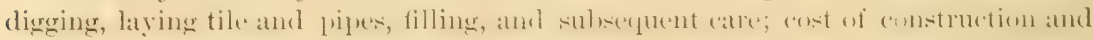
efficiency; sewers for the disposal of waste water from farm buildings and the sewage from kitchen and toilet; farm water pipes, pipe and thread cutting. Class work, laboratory and field practice. I; first half; daily; 6,$7 ;\left(2 \frac{1}{2}\right)$.

5. Furm crops-(guality and improrement.-Judging of corn (see Exhibit 8, p. 30) and

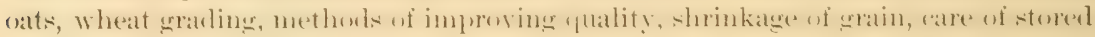
crops to prevent injury and loss. Class and laboratory work. I; first half; daily; $6,7$ (or 3,4$) ;\left(2 \frac{1}{2}\right)$.

6. Furm crops-Germination and grouth. - Vitality and gemination of seeds, preservation of seeds, methods of seeding; conditions of plant growth; peculiarities of

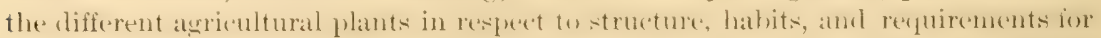
successful growth; enemies to plant growth; weeds and weed seeds, their identification and methods of destruction; fungus diseases, such as smut of oats and wheat, and blight, scab, and rot of potatoes, methods of prevention; insects injurions to farm crops and how to combat them. Class room, laboratory, and field work. II; first half; daily; 6,$7 ;(21)$.

7. Special crops.- 1 special study of farm crops taken up under an agricultural outline-grain crops, root crops, forage crops, sugar and fiber crops-their history

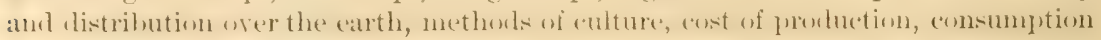

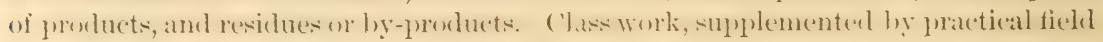
work and a study of the results of previous experiments, such its detasseling corn, injury to roots of corn by cultivation, selection and breeding of corn and other crops, with special reference to practices which apply directly to Illinois conditions. stuclents will have an excellent opprortunity to stuly the work of the derieultural experiment station. II; daily; 1, 2; (5). Required: Agronomy 2, i, 6.

8. Field experiments. - Special work by the students conducted in the field. This work consist. in testing varieties of corn, wats, wheat, petateres, and other fam crops; 


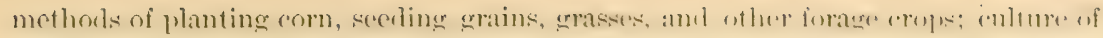
corn, potatoes, and sugar beets; practice in treating oats and wheat for sumb and potatoes for scab and studying the effects upon the erops; combating chinch bugs and other injurious insects. Other practical experiments maty be arranged with the instructor. Special opportunities will be given to advanced students of high class standing to take up experiments, under assigmment and direction of the instructor in farm crops, on certain large farms in the State, arrangements having been made with the farm owners or managers for such experiments. II, second half, and summer vacation; daily; arrange time; (21 to 5$)$.

Required: Agronomy 7,12 .

9. Soil physics and management.-This course is designed to prepare the student

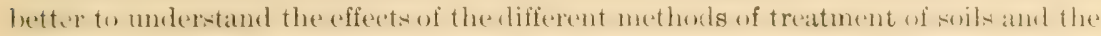

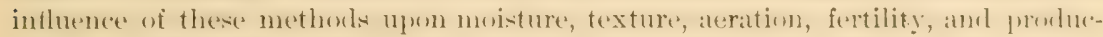
tion. It comprises a study of the origin of soils, of the various methods of soil formation, of their meehanial composition and elassitieation; also soil mosisture and

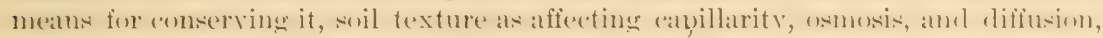
as affected hy plowing, harrowing, coltivating, mollinge, and croplphes of the watsting

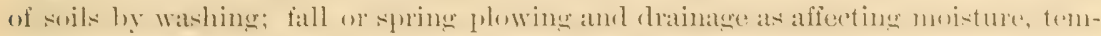
peratures, and root development. The work of the class room is supplemented by

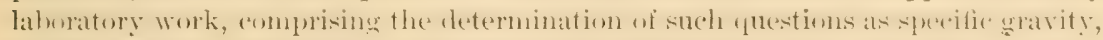

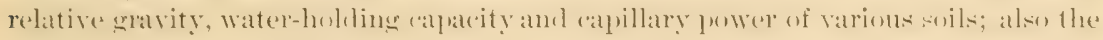
study of the physical effects of different systems of rotation and of continuous cropping with various crops, and the mechanical analysis of soils. I; daily; 1,$2 ;(5)$.

Required: Physics 1, 3 (first semester's work), and Agronomy, 2.

10. Special problems in soil physics. - This work is intended for students wishing to suecialize further in the stuly of the physical propertiens whils, and will include the

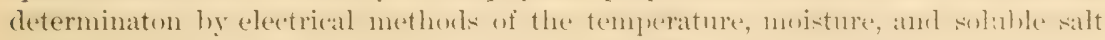
content of various soils under actual field conditions; effect of different depths of plowing, cultivation, and rolling on soil conditions; effect of different methods of preparing seed beds; the physical questions involved in the formation and redemption of the so-called "alkali," "barren" or "dead dog" soils, and of other peruliar soils of Illinois. II, or summer vacation; daily; arrange time; (5).

Required: Agronomy 9.

11. Soilbactoriolog! - A study of the morphology and activities of the bacteria which

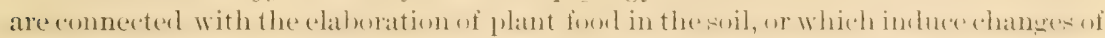

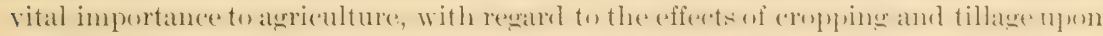
these organisms, and with special reference to the study of those forms which are concerned with the formation of nitrates and nitrites in the soil and with the accumnlation of nitrogen by leguminous crops. Class room and laboratory work. II; daily; 6,$7 ;(5)$.

Required: Botany 5; Chemistry 3b, 4.

12. Fertilizers, votations, and fertility. - The influence of fertility, natural or supplied, upon the yield of various crops; the effect of different crops upon the soil and upon

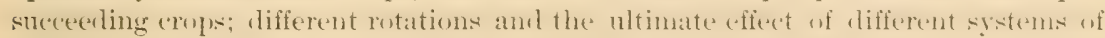
farming upon the fertility and productive capacity of soils. The above will be supplemented by a laboratory stmly of mannres and fertilizers, their compusition and

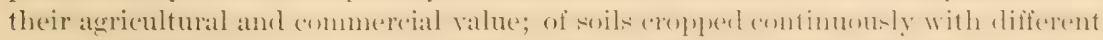
crops and with a series of crops; of the fertility of soils of different types, or classes from different sections of Illinois. II; daily; 1, 2; (5).

Required: Chemistry 13; Agronomy 6, 9.

13. Inxestigation of the fertility of special soils. - This course is primarily designed to enable the sturlent to sturly the fertility of those suecial suils in which he mat he particularly interested, and to become familiar with the correct principles and methols of such investigations. It will inclule the determination of the nature and 
quantity of the elements of fertility in the soils investigated, the effect upon varions crops of different fertilizers added to the soils, as deternined by pot cultures, and, where possible, by plat experiments. This work will be supplemented by a systematic stuly of the work of experinent stations and experinenters alome the lines of investigations. I, II; arrange time; (2 to 5 ).

Required: Agronomy 12.

14. History of agriculture.-Its development and practice, with particular regard to the ayriculture of these nations which have onntributesl most to agrioultural progress, including a sketeh of the earliest agrienltural practices as illustrated hy the agrienlture of the Eyrgtians, the Jews, the (hinese, and other ancient perples; followed loy a stuly of the development of Roman agriculture and its influenees upun the puatices in other nations; a consileration of the begimings and systems of British asrienture with regard to their influence upon social conditions; and, finally, the development of modem agriculture with special reference to that of England, Germany, France, and the United States. I, second half; daily; $3 ;\left(2 \frac{1}{2}\right)$.

15. Comparative agriculture.-Influence of locality, climate, soil, race, customs, laws, religion, etc., upon the agriculture of a country, and incidentally upon its people. One crop only, and its effect, as rice; Indian corn in American agriculture and affairs. Varying conditions under which the same crop may be produced, as wheat. Statistical agriculture. Influence of machinery and of land titles, whether resting in the govermment, in landlord, or in occupant. Relation of agriculture to other industries and to the body politic. Lectures. II ; F; 4 ; (1).

Required: 'T'wo years of University work.

16. German agriculturul readings. - A study of the latest agricultural experiments and investigations published in the (ierman language, special attention being given to soils and crops. The current numbers of cierman journals of agricultural science will be required and used as a text. This course is designed to give the student a broader knowledge of the recent advances in scientific agriculture, and, incidentally, it will aid him in making a practical application of a foreign language. It is recommended that it be taken after Agronomy 12. II; M., IV. $t ;$ (2).

Required: 'Two years' work in German.

17. Special work in druinerge amel machinem. - Students may arrange for special work in any of the lines covering irainage or farm machinery, either in the secom semester or the summer. ( $\left(22_{2}^{1}\right.$ to 5 .)

18. Inrestigation and thesis. - This course varies in the subject matter of study, according to the department in which theses are written. 'The work is under the direction of the hear of the departinent. I, II; arrange time; (5 to 10).

The offices, class rooms, and laboratories of the department of agenomy are housed in the agrencoltural huilding (1'l. I), which wats

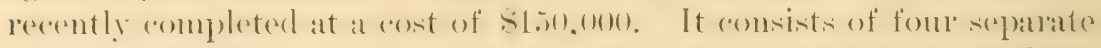

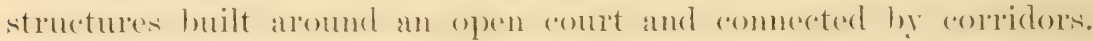

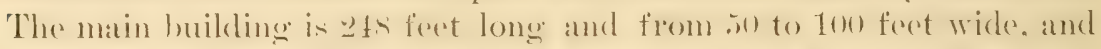

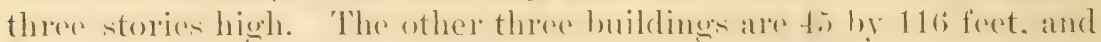
two stories high. These huilding ate of stone and hriek, roofod with

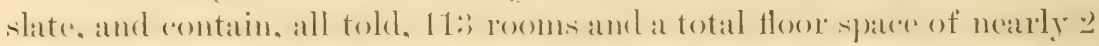

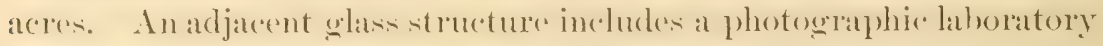
and a pot-enlture laboratory for the department of aglomoms. Ser-

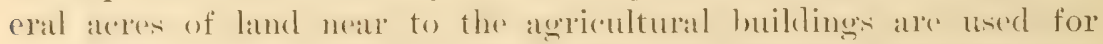
instrution in agromomy. ehiefly hy means of student experiments.

Aside from the work in farm merhandes, the department of agronomy includes four principal divisions, viz, soil fertility, soil physics, soil 
bacteriology, and farm erops. Sereral courses of instruction are

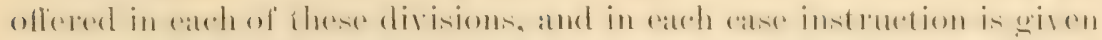
by the laboratory method, as well as by text-books, lectures, and reforemere readings. Two latheratories are provided for the work in

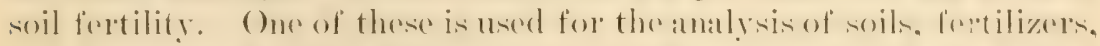
and manures: for the determination of the elements of plant food contained in plants and plant products, and for the prepratation of soils for pot culture experiments, which include the une of sand cultures. Watcre cultures, and soil cultures, with the addition of chimination of any or all of the liflerent clements of plant food (P'l. III, lig. 1). The second is the pot-rulture laboratory (Pl. III, fig. 2), which is located in the ereenhouse near the agricultural buikling, and in which the pot-culture rexperiments are carried on by the students as a pat of his regular laberatory pratedier. The soil fertility analytical laborattory is prosided with deske for In students" places, arch desk being made deuble. so that by working two sedions 36 students can be acemmodated. All applatatus necessary for the analy sis of soils, fertilizers, ote. is povided, including andytical balanees, digestion

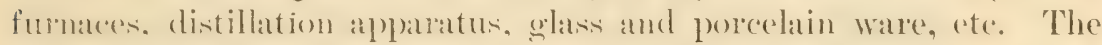
laberatory is provided with a hood under which operations which

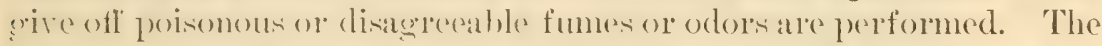
deskis are piped for gas, (ompressed air, ralcum and water, and provided with sinks and waste pipes. The feretility pot-colture laboratory is provided with sultable tahles and with sereral hundered glazed pots of diflerent sizes suitahle for pot-culture experiments. Most of the water used in the pot-retture experiments is drawn from a

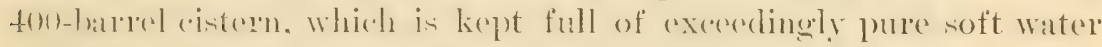

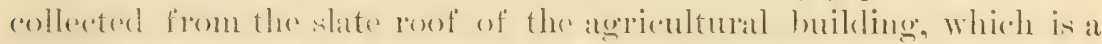
guartere of a mile distant lrom the central heating plant of the mi-

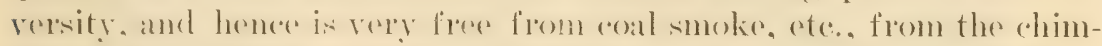
neys. For special purposes, distilled water is provided and, when necessary, nitrogen-free water is used.

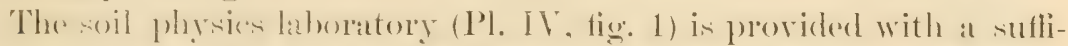
(ient number of derkis to allow 24 students to work at one time and, by rumning two sections, tis students an he ateommerdaterd. This latroratory is woll opuipered with the apparatus necessary for studying the physen of soil. including (entrifugal mathines and shaking aplat-

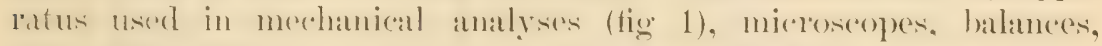
compacting appanatus. apparatus for determining the water content, ahsorptive (apateit!. Water-holding powor", and sperefic gravity of soils; sereral alectrical instruments for the determination of temperature. moisture, and soluble salt content of soils: a :3-horsepower electric motor with a line shaft, counter shaft, belting, ste.; elutriators, furnateres, sieress, and mumb of here general appatratus. The laboratory is also presided with at side tahle, heod, latege drying oren, and store- 
room. For theswork in farm drainage the department of agronomy is provided with several surverors leveling instruments, chatins, and bupelines. and all nexessaly fools for rumning ditches and laying tile. students are given a comsiderable anomnt of praction in survering systeme of dratinage, rumning lerels. digging ditches, and laying tile.

Two laboratories are provided for the study of soil bacteriology. although one of these is also used during part of the year for heginning students in general bacteriolegey. Thirty-two student plates are provided for. The laboratory is equipled with incubators. miero-

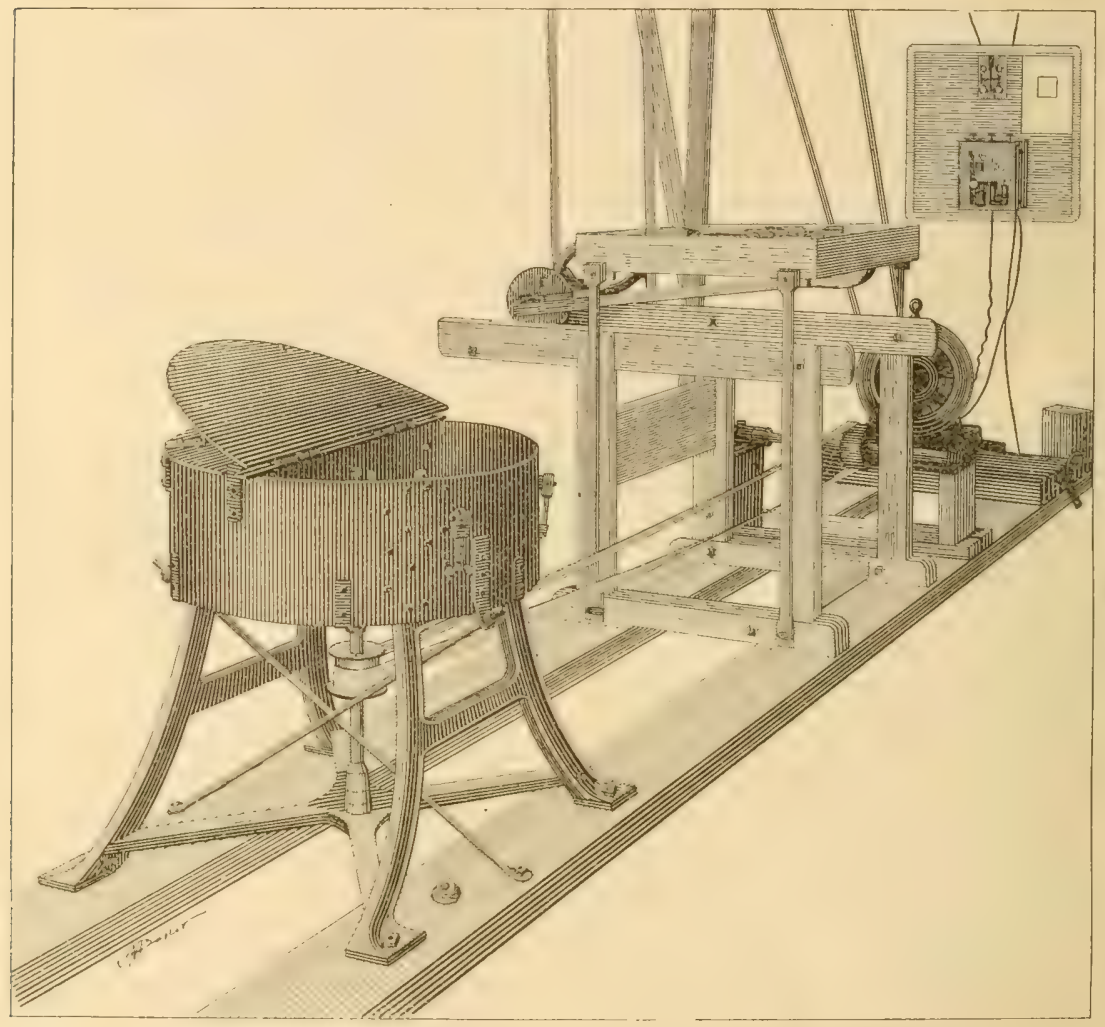

FIG. 1.-Centrifuge, shaker, and electrie motor used in mechanical analysis of soils.

scopes, antoclaves and othere sterilizing apparatus. balanees, and of heer materials needed for barteriological work, including saining solutions, rhemieals. mediate cote. The hood tables and the tile-top) side tables are provided with steam baths, gas, air, valcumm, and water pipes, and waste sinks. Adjoining the laboratory are a store room, an incubating room, and an animal room with cages for keeping animals under experiment.

Two laberatories are provided for the work in farm erops (Pl. IV, tige 2 ), one of which has 36 student places, and the other $2+4$ places, 


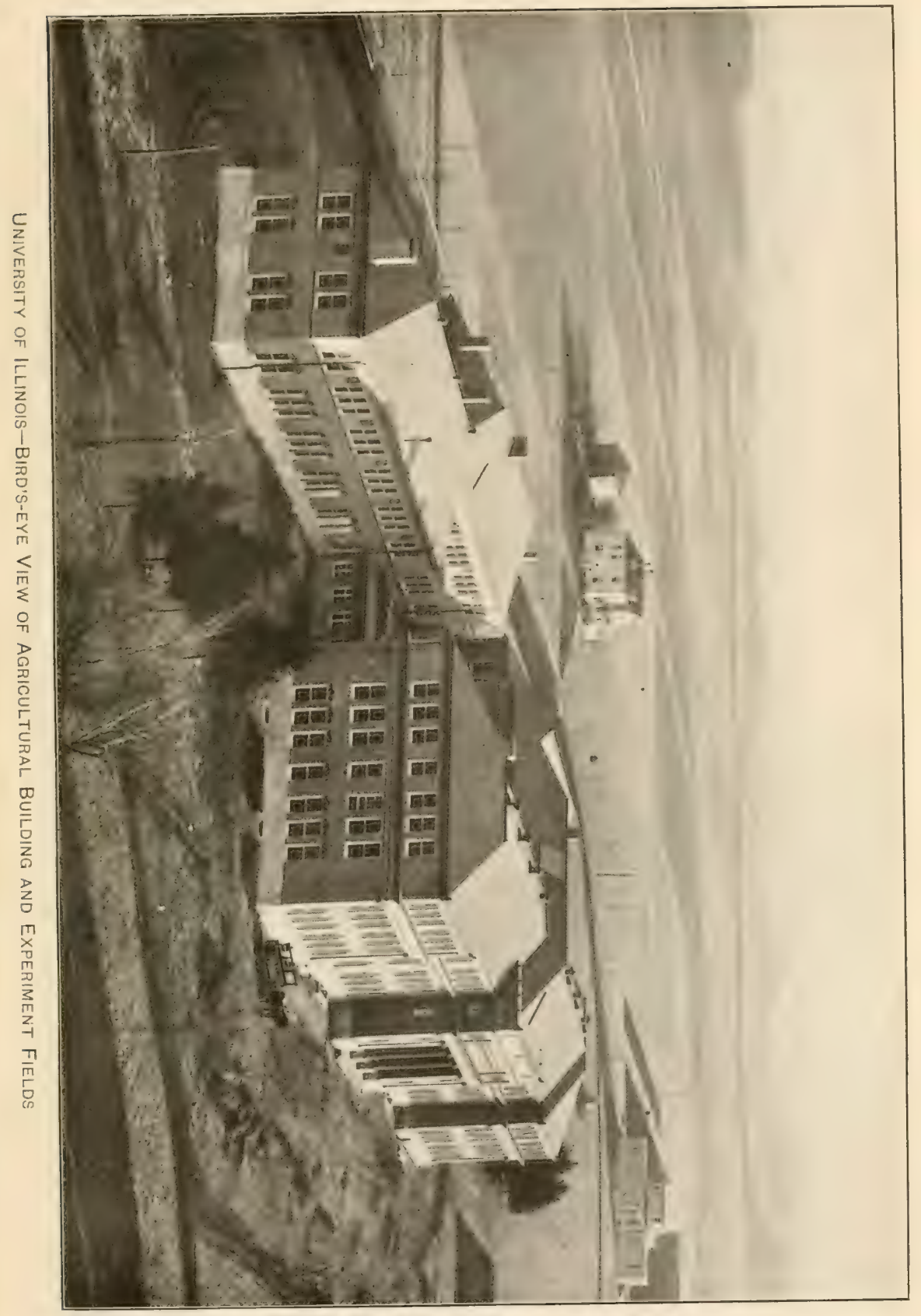





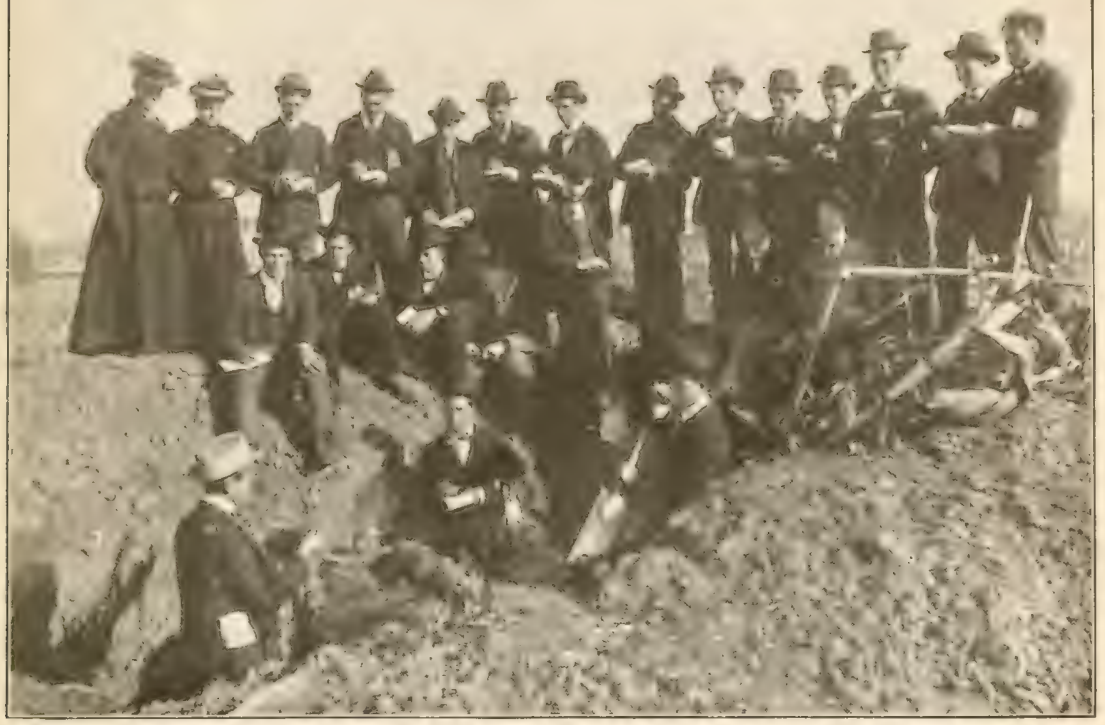

Fig. 1.-University of ILLINOIS-CLASS IN AgRonomy STUdying ROOT DEVELOPMENT OF CORN.

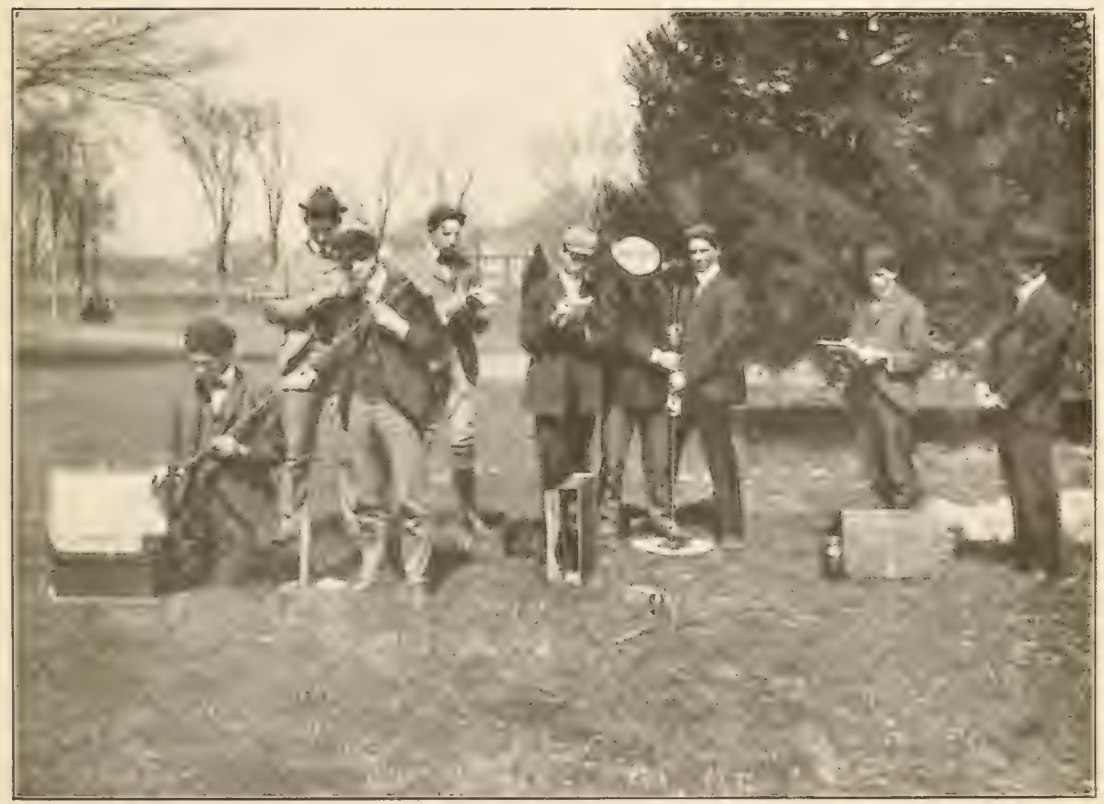

Fig. 2.-UNIVERSITY OF ILLINOIS-CLASS IN AgRONOMY COLLECTING SAMFLES OF SOIL. 



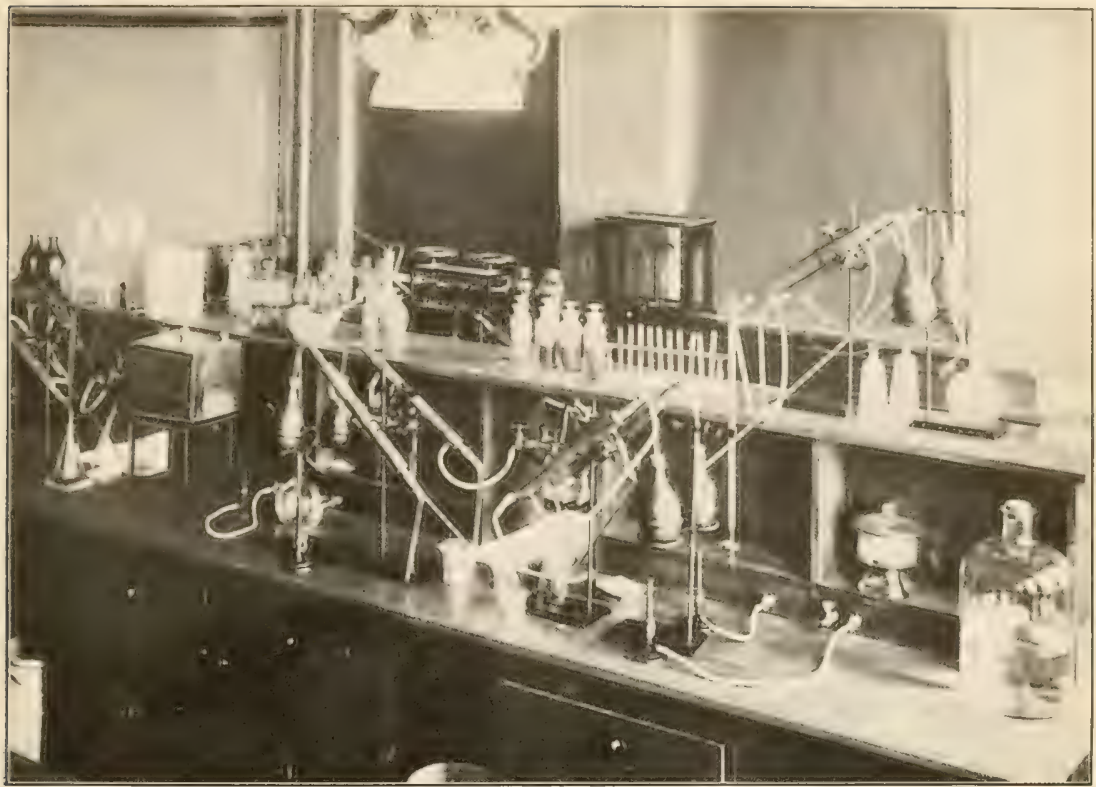

FIG. 1.-UNIVERSITY OF ILLINOIS-SOIL FERTILITY LABORATORY FOR ANALYSIS AND SYNTHESIS OF SOILS AND FERTILIZERS.

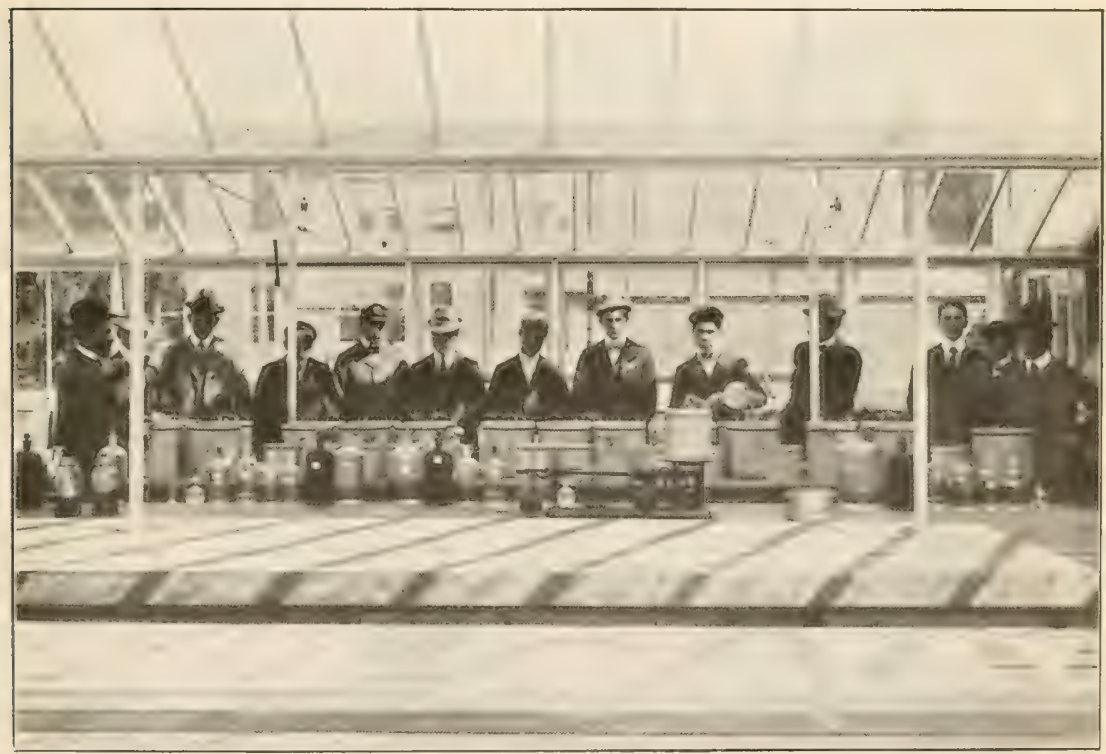

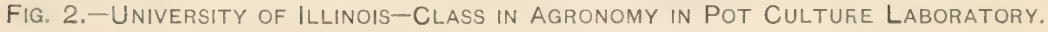





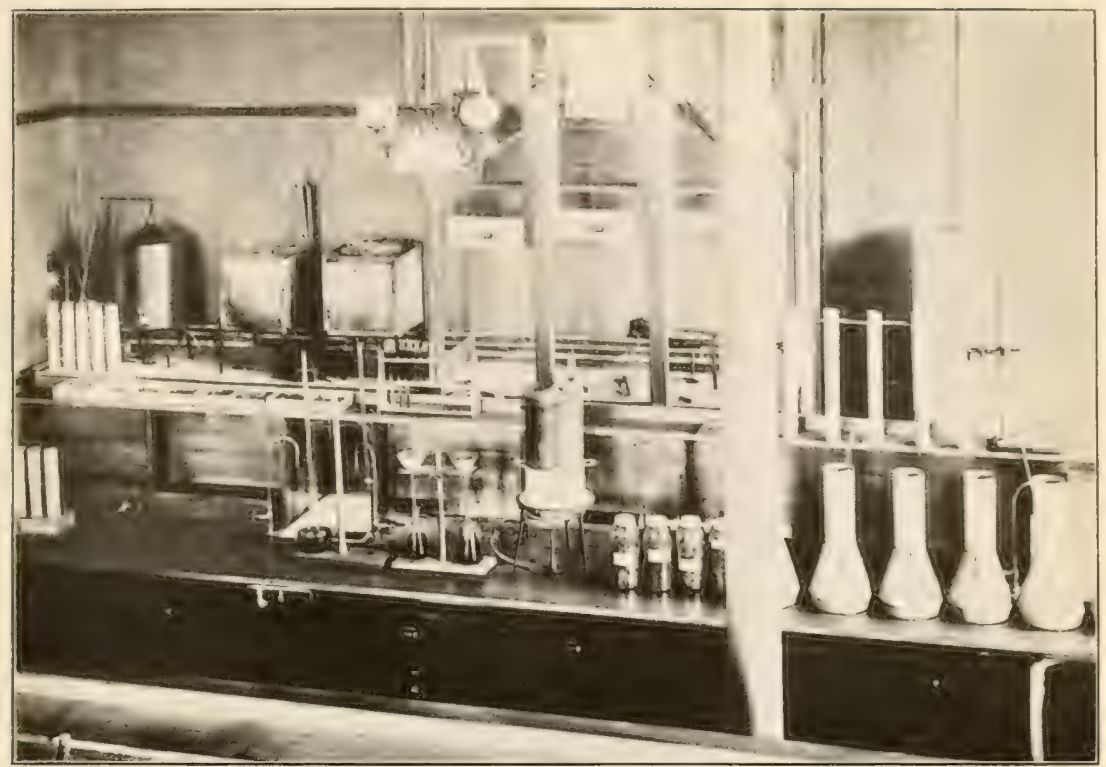

FIG. 1.-UNIVERSITY OF ILLINOIS-SOIL PHYSICS LABORATORY.

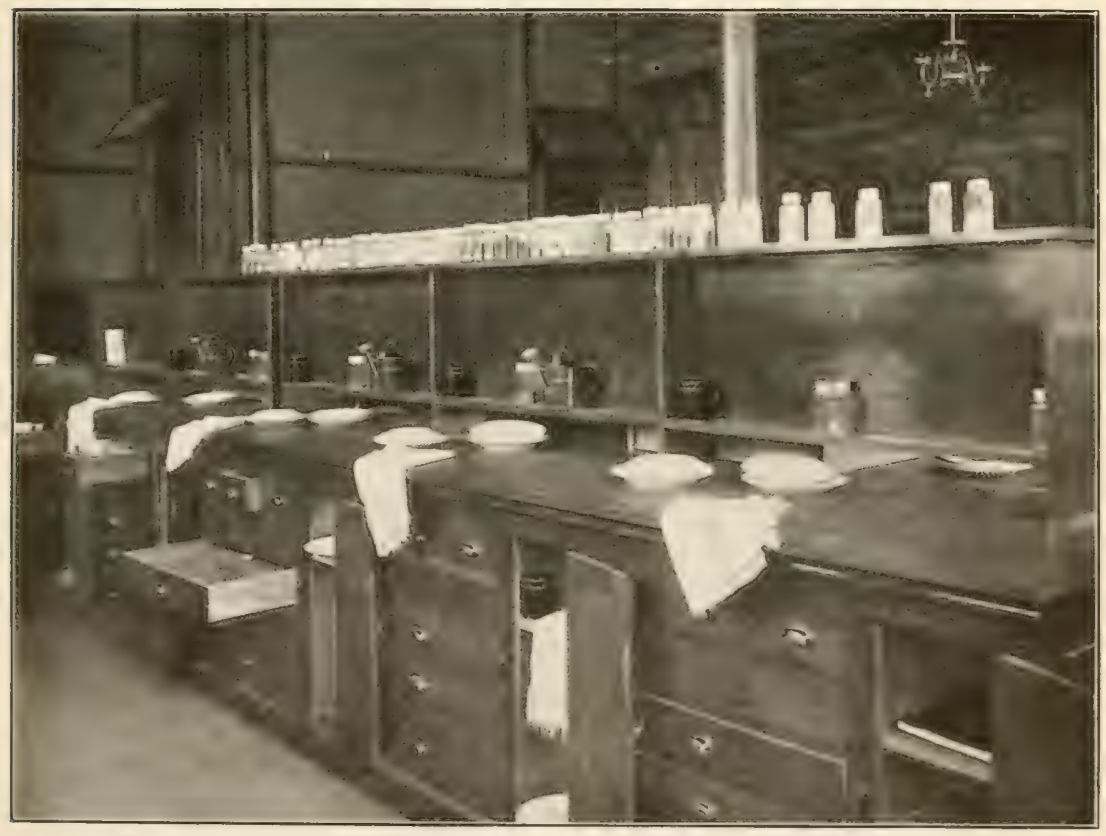

FIG. 2.-UNIVERSITY OF ILLINOIS-FARM CROPS SEED LABORATORY. 



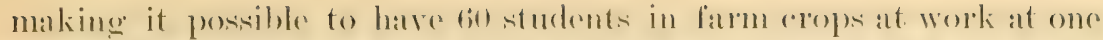
time. These deskis ane provided with a latege numbere of dratwers for

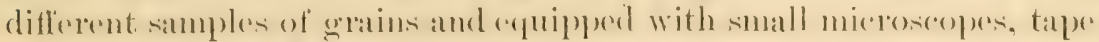

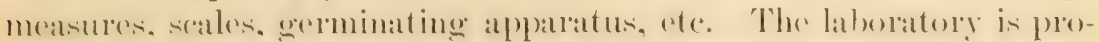

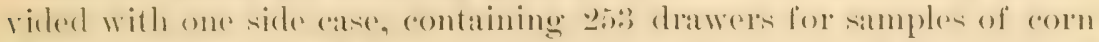

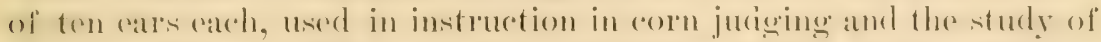

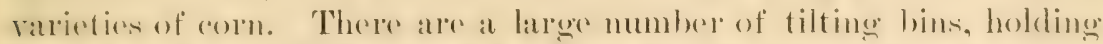

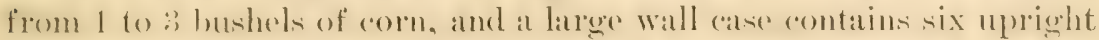

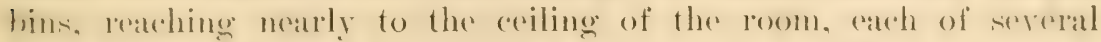

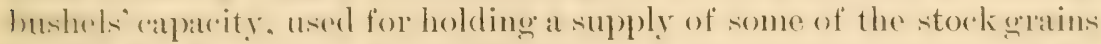

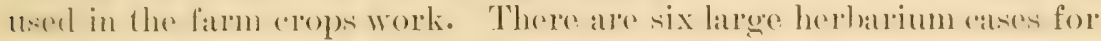
proserving speromens of diflerent farm crops and of woeds injurious to farme (ropks. There is also a cabinet provided with a latege number

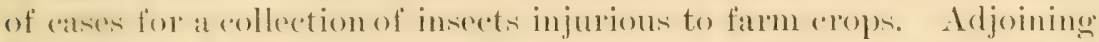

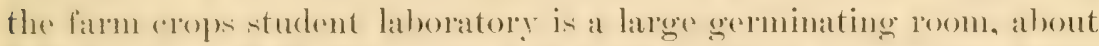

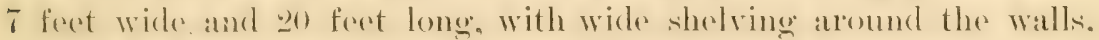
rxtending from near the floor to the ceiling giving suflicient space for

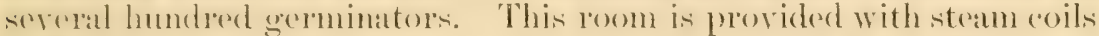

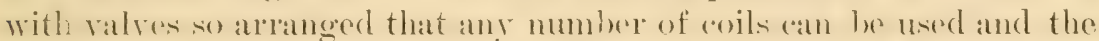
temperature of the room regulated as may ho desirend. A large colec-

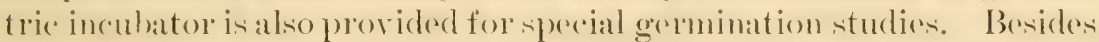
the laboratory practice the students in farm repos cary on plat experiments under field conditions, several andes being provided for this purpose and hand tools lxing provided for student use.

Among the text-books and reference bookis most latrocly used in the comser in soil fertility are Aikman's Manures amel the Principles of Manuring, Voorheesis Fertilizers, Roherts's Fertility of the Land,

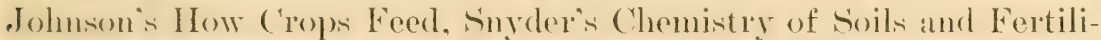

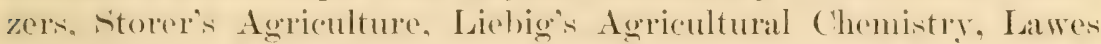
and (iilhert's Reports on Agricultural Investigations at Rothamsted, and the bulletins and reports of the C'nited Stater loppartment of Agriculture and of the various State experiment stations.

Amonge the books used in soil physies are The soil and The l'hysies of Aoriculture, by King; Rocks and roils, by Storkhridge; Origin and Satme of Fioils." hy S'haler" and Land Drainage. hy Miles.

Bookis used in soil bacteriology are Manual of Bateroblogy, by Siternherg: ('onn's Igricultural Bacteriology; and Fischer's Structure and Functions of Bacteria.

Among the bookis used in the study of farme rops are olohnon's

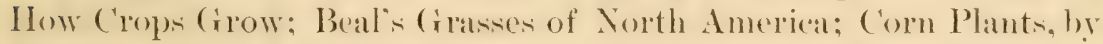

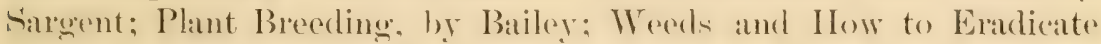
'Them, by Shaw; and Storer's Agriculture.

In addition to these books the library of the l'niversity of Illinois

"T'welfth Annual Report of the U. S. Geological Survey, Part I-Geology, pp. 213-345. 
contains sereral hundred rolumes, journals, and pamphlets, ini English, German, and French, relating in part or wholly to the subject of agronomy. These are aceessible to all of the sturlents in the department, but are used more largely by students engaged in research work.

Laboratory, lecture. or field notehooks are reguired to be kept by students in all courses in agronomy. and in most courses students are

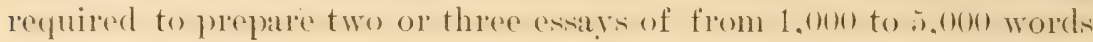
earlo during the semester. Is a rule. preliminary examinations ale given at the end of each month and a timal examination at the close of the rourse. 'The student's standing or grade for the semester's work is based upon four factors: (1) Clasis recorth of recitations; (2) prelimimary examinations and written exereises: (:3) fecture, laboratory. or field notebooks; and (4) final examinations.

I) ring the past gear about eno students took work in courses in

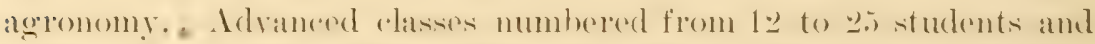

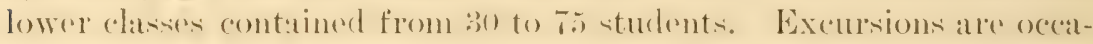

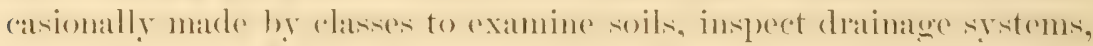
to visit tields and other platere of spereial interest and importanee to the work of the classes.

Aside from the help of several student assistants, there are six regular instruetors in the department of agronomy. () ne oflers courses in soil fertility, another in soil physics at thire in farm drainager and irrigation, a fourth in soil bacteriology, and two other instruetors give courses in farm crops.

\section{Eximitr No. 3.}

\section{JUDGING CORN.}

Students in farm arops. when juelging corm, are provided with stifl cardhoard corers : by to inches, in which special blank forms for soring may be fastened. (On the inside of the front cover is pasted Form 1. giving standards for varieties. explanation of points. and rules to be nesed in juelging. (On the inside of the hack cover and

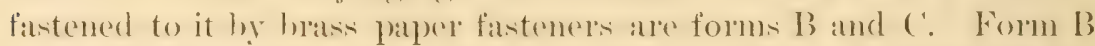
is used by the student in seroring a single cal of corn, and Form (' for recording the corrected scores of sereral ears.

lonse A.-Directions for scoring.

STANDARDS FOR VARIETIEK.

\begin{tabular}{|c|c|c|c|}
\hline Name of variety. & $\begin{array}{l}\text { Length of } \\
\text { car. }\end{array}$ & $\begin{array}{l}\text { Circumfer- } \\
\text { ence of } \\
\text { ear. }\end{array}$ & $\begin{array}{l}\text { P'roportion } \\
\text { of corn to } \\
\text { cob. }\end{array}$ \\
\hline 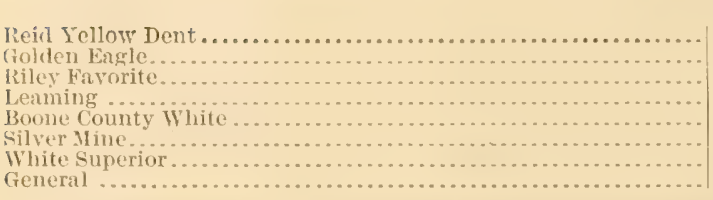 & $\begin{array}{c}\text { Inches. } \\
10 \\
9 \\
9 \\
10 \\
10 \\
9 \\
8.5 \\
10-11\end{array}$ & $\begin{array}{l}\text { Thehes. } \\
\qquad \begin{array}{l}7 \\
\frac{7}{7} \\
\frac{7}{7} \\
\frac{7}{7} .5 \\
7 \\
7.5-8\end{array}\end{array}$ & $\begin{array}{r}\text { Per cent. } \\
88 \\
90 \\
90 \\
88 \\
86 \\
90 \\
88 \\
88\end{array}$ \\
\hline
\end{tabular}


R.TLANTION OF PMNTS.

1. Uniformity: Uniform shape, size, indentation, and type of ears.

2. Shape: Shape of ear should conform to variety type, usually cylindrical, i. e., of equall circumference from butt to tip.

3. Color: Free from mixture and true to variety color.

t. Market condition: Ripeness, soundness, ear firm and well matured.

5. Tip: Kernels filled over the tip in regular manner.

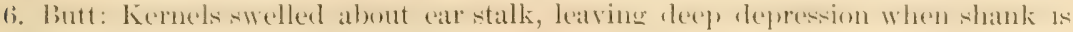
removed.

7. Kernel, uniformity: Uniform shape, size, and conformity to variety type.

8. Kernel, shape: Wedge shaped, straight edges, and large germ.

9. Length: Varies with the variety, measure.

10. Circumference: Varies with the variety, measure.

11. Space: Furrow between tops of rows of kernels.

12. I'mpertion: I'roportion of weight of erain to enh. Ir cight varies with variety.

RULES TO 13E USED IN IUIGING.

1. The deficieney and excess in length of all ears not conforming to the standard for the variety shall be added together, and for every 2 inches thus obtained a cut of un puint shall le male. In determining length, neasure from the extreme tip to the extreme butt.

2. The deficiency and excess in circumference of all ears not conforming to the standard of the variety shall be added together, and for every 4 inches thus obtained a cut of one point shall be made. Measure the circumference at one-third the distance from the butt to the tip of the ear.

3. In determining the proportion of corn to cob, weigh every alternate ear in the exhibit. Shell and weigh the cobs, and subtract from weight of ears, giving the weight of corn. Divide the weight of corn by total weight of ears, giving the per cent of corn. For each per cent short of standard for the variety a half-point cut shall be made.

4. In judging color, a red cob in white corn, or a white cob in yellow corn, shall be cut ten points. For one or two mixed kemels, a cut of one-fourth point; for three or four mixenl kemels, a cut of whe-half point; for five mixed kernels, a three-fourthspoint cut; or for six or more mixed kernels, a one-point cut shall be made. Kernels missing from the ear shall be counted as mixed. Difference in shade of color, as light or dark red, white or cream color, must be scored according to variety characteristics.

5. 'To determine the cut for space, the following rules can be applied if combined with the judgment of the student: For less than one thirty-second inch, no cut; for a furrow one thirty-second to one-sixteenth inch, one-half point; formore than onesixteenth inch, cut one point. The looseness of kernels on the cob does not apply to space, but to maturity. The furrows or angle between the tops of the rows of kernels is the space between rows. 
Fors B.- For individual semple.

Date, STUDENT'S REPORT JUDGING CORN.

Number of exhibit.

Name of variety,

Length,

STANDARI OF VARIETY.

Cireumference,

Proportion grain to cob,

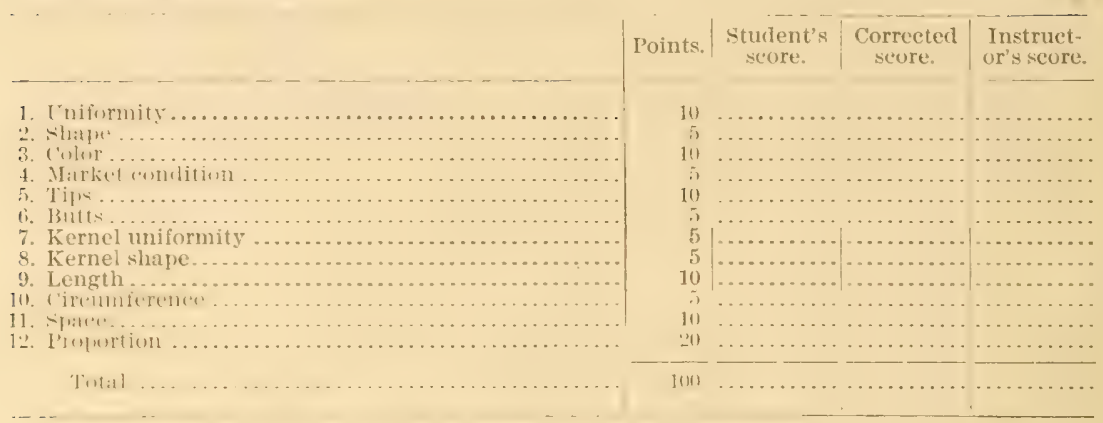

IREMARKX.

Fons C.-For several stomples.

1. Inifurmity.

$\therefore$ - Shathe of tiat.

3. Purity uf eutor

4. Market eonclition

$\therefore$ Filline whlt lip.

6. Filling out butts

7. Kernel uniformity

8. Kernel slatpe.

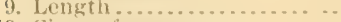

10. Ciremmference

11. Space between fows.

12. l'roportion of corm to colj....

Tot:11

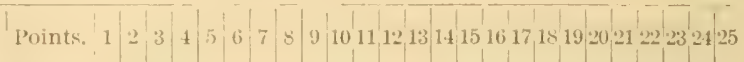

HXIIIITT No. $t$.

STUDENT'S LABORATORY BLANKS IN SOIL PHYSICS.

Experiment io. 1 .

MOTSTURE-COPHALARY.

Use sand, clay, loam, and gravel as provided.

1. Weigh carefully four drying pans.

2. Place in one of each about 100 grams of each of the above soils.

3. Weigh the pan and soil carefully:

4. Spread out the soil to a thin layer by shaking, and dry for twenty-tour hours at room temperature.

5. Weigh and repeat the drying and weighing at intervals of four to five hours until a nearly constant weight is obtained.

The loss of weight represents the amount of eapillary water.

Amount of eapillary water found was: Sand, loam, gravel,

Define eapillary water: 
DETELMINATION OH HYGROSCOPL MOISTURE,

Use the air-dried soils from experiment No. 1.

1. Place about 10 grams of the air-dried soil in a tared porcelain crucible $(a)$.

2. Weigh the soil and crucible $(b)$ and heat in the air bath at $i 00$ to $110^{\circ} \mathrm{C}$. for 1 hour.

:). ('onl in at desceater and weigh rapidly to prevent alsorption of moisture irom the air.

4. Ileat for a shorter time, cool, and weigh, repeating until the weight (r) becomes ('onstant.

Calculation: The luss of weight, or h--e, equals the amomt of hygroseopice water in the sample taken.

$c-a$ equals the weight of water-free soil.

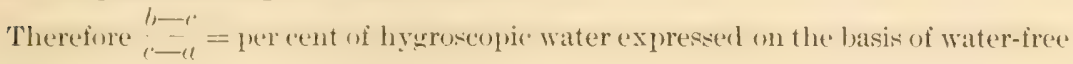
soil.

The per cent of hygroscopic water found was: Sand, _-; clay, _-; loam, - ; gravel,

Define hygroscopic water:

From the results ubtained in experiments 1 and 2 compute the percentage of (apillary and total water in the soil, expressed on the basis of water-free soil.

Total water content is (percentage). Sand, _-; clay, _- ; loam, - . ; gravel,

In adrition th the capillary and hygrosengic water, the soil may contain, muler some conditions, as immediately after a rain, a certain amount of free or gravitational water. This portion of the soil water is acted upon by the force of gravity, which causes it to percolate downward to the level of the ground water.

\section{Experiment No. 3. \\ HILGARD'S FLOCCULATION EXPERIMENT.}

Two students will work conjointly in this experiment.

1. Into each of four beakers place about 1 gram of clay and add 200 cubic centimeters of water.

2. To beaker-

No. 1 add 0.2 gram ealcium hydrate $=0.1$ per cent solution.

No. 2 add 1 gram calcium hydrate $=0.5$ per cent solution.

No. 3 add 2 grams calcium hydrate $=1$ per cent solution.

No. 4 add 0 gram calcium hydrate $=$ Control.

:3. With a stirring rod mix the contents of each beaker thoroughly and then place a sample of cath in a Vessler's cylinder and whirl in the centrifuge at the lowest speed and note the time required to completely precipitate each solution.

4. Pour the contents of each cylinder back into the respective beaker, stir thoronghly and set asile, ohserving oceasionally to determine the time reyured for complete sedimentation in each case.

('ompare in each ease the cylinder's and heakers containing the different strengthes of solution and the control and tabulate the results in the space below.

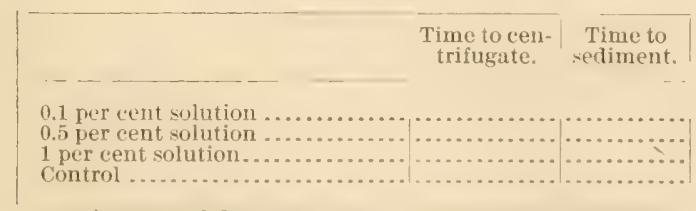

Explain how the lime acts and clarifies the water: 
Experiment No. 4 .

EFFECTS OF LIME ON PLASTIC NOILS,

Two students will work together as in experiment No. 3.

1. Weigh out five 50-gram samples of the clay soil.

2. To sample-

No. 1 add 0.5 per cent calcium hydrate.

No. 2 add 1 per cent calcium hydrate.

No. 3 add 5 per cent calcium hydrate.

No. 4 add 10 per cent calcium hydrate.

No. 5 add no calcium hydrate.

3. Mix each sample thoroughly in a soil pan, and add just enough water to make plastic.

4. Fill into molds in the form of sticks, using care to compress all samples to the same degree, and transfer to the oven and bake at $110^{\circ} \mathrm{C}$. for 4 to 5 hours.

5. Test the strength of each stick of baked clay by supporting upon blocks and suspending weights until the clay is fractured. Note weight required in each case and fill in results below:

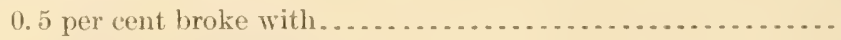

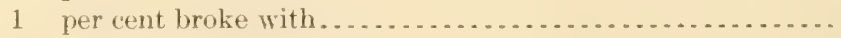

$\therefore$ per rent broke with . . . . . . . . . . . . . . . . . . .

10 per cent broke with . . . . . . . . . . . .

Control broke with . . . . . . . . . . . . . . . . . . . . . . . . . .

Grams.

Explain the loss of plasticity due to the lime:

\section{Experiment No. 5 .}

DETERINATION OF THE APPAREXT NPECIFIC (HRATTY OF NOIL,

Use each of the four soils as in former experiments.

1. Weigh carefully in empty and thoroughly eleaned soil tube (a).

2. Fill it with one of the soils to be tested, which must first be well pulverized if lumpy. In filling use the soil-compacting machine, allowing the weight to fall three times from the 6-inch mark upon each cupful of soil. Fill the tube to the crease near the top.

3. Weigh the filled tube carefully $(b)$.

4. The area of the bottom of the tube is 20 square centimeters. From this compute the number of cubic centimeters of soil which it contains (c).

5. Determine the amount of hygroscopic moisture in a special sample of the soil, aceording to direction given under Experiment No. 2 (d).

Culculutions:-

$$
b-(a+d)=\text { weight of the given volume of soil. }
$$

Therefore, $\frac{b-(t+d)}{c}=$ weight of $1 \cdots$ of soil=volume weight of soil.

$\frac{\text { Volume weight of soil }}{\text { Volume weight of water }}=$ apparent specific gravity.

I find the apparent specific gravity to be as follows: Sand, —_; gravel, —_; loan, — ; clay, -.......

The volume weight or apparent specific gravity of soils varies with the amount of packing, a freshly plowed field being much lighter per cubic foot than one compacted hy rains or tramping.

Explain the object of using the soll-compacting machine in this experiment. 


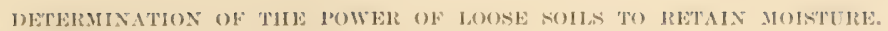

1. Place 100 grams of the air-dried soil in a beaker and add 100 cubic centimeters of distilled water.

2. Mix the soil and water thoroughly and rinse the soil upon a previously saturated filter with a known amount of distilled water. Cover the top of the fumnel with a glass plate to prevent evaporation.

3. Catch the water which drains away, in a graduate, and deduct the amount of water caught from the total amount used. The remainder represents the amount retained by the soil.

4. With a special sample of the soil used determine the per cent of hygroscopic water.

Culculation.-After finding the per cent of hygroscopic water, determine the amount of water-free soil in the 100-gram sample taken. Add the total amount of hygrosenpe water to the rapillary water retained and divile the sum hy the weight of water-free soil, and the quotient will represent the per cent of water held, calculated on the basis of water-free soil.

Per cent of water retained was: Sand, clay, gravel,

Why do you use air-dried soil in this experiment?

Why do you moisten the filter?

\section{Experiment No. 12.}

DETERMINATIOS OF TIE RATE OF PERCOLATION OF AIR THROCGH NOLLS.

1. Fill the series of tubes provided for this experiment with the finely pulverized and sifted soils without compacting.

2. Attach the tubes successively to the aspirator and note the length of time required to force or draw 10 liters of air through each sample of soil. The aspirator weight must be started from the same height in each case.

This experiment illustrates the relative aeration of soils, a question which is of importance in connection with the subject of the growth and development of the nitrifyine and other hateria of the soil comeerned in the problution of phant foxd.

Time required for sand, ___ ; gravel, __ ; loam, _— ; clay,

Eiperiment No. 13.

CAPILLARY ATTRACTION OF SOILK.

1. Close the lower end of 12 of the large glass tubes by a piece of thin muslin tied firmly to the tubes. The tubes are then filled with the finely pulverized air-dried soils, which have been earefully sifted to remove all small stones. These tubes are to be filled with each soil-No. 1, by simply pouring the soil as loosely as possible into the tube; No. 2, by compacting the soil gently by tapping the lower end of the tube upon the bench, and No. 4 , by compacting the soil by ramming with a rod. Care must be taken to compact the different soils to the same degree, both in the jarring and ramming, by jarring or ramming each tube the same number of times.

The tubes are now placed in the supporting frame in such a manner that the lower ends shall dip one-half inch beneath the surface of a tray of water.

The experiment is now ready for observation at intervals of twenty-four hours, when the height to which the water has risen is carefully measured and recordent. 
These observations should be taken daily for one week, and the results are to be noted below.

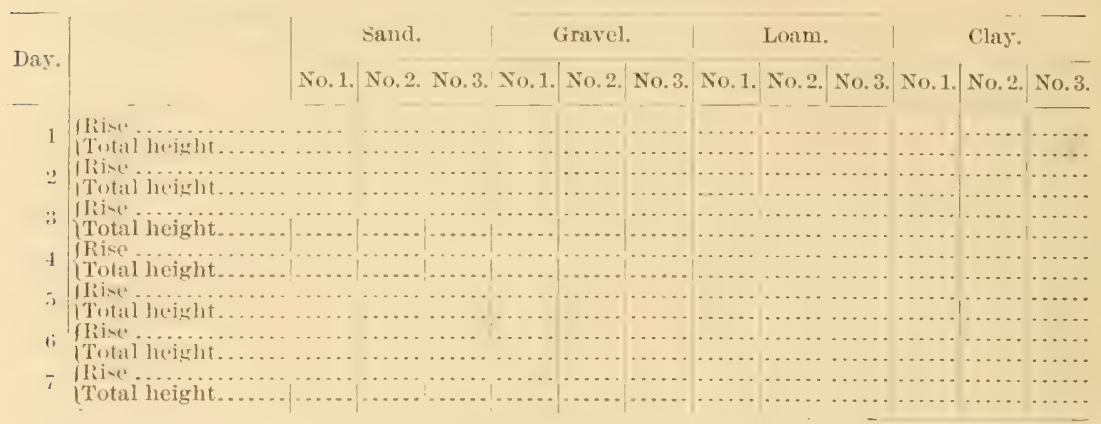

To obtain accurate and reliable results it is necessary to use great care in filling the tubes, observing in particular that there are no places where the column of soil is unerenly packed or broken by coarse material which will prevent the action of capillarity.

\section{Experiment No. 14.}

EFFECT OF CULTWATION OR DUST MULCIES ON EYAPORATION OF WATEI FROM SOLLS.

Fill all the tubes with the fine prairie soils, using the compacting machine. All the tubes should be filled to the same level.

The conical bases of the tubes are then filled partly full of water, so that the water shall stand at the same level in each. Determine the level with the S-shaped glass tube, and measure the depth of water very accurately with the millimeter rule. The tubes are to be filled to the same level each day, and the amount of water added is carefully noted. This amount represents the water lost by evaporation. The tubes are treated as follows: Tube 1, control; tube 2, cultivated 1 inch; tube 8 , cultivated 2 inches; tube 4 , cultivated 3 inches; tube 5 , cultivated 4 inches; tube 6 , cultivated 5 inches.

The cultivation is performed each day by removing a layer of soil to the depth of cultivation used in the tube, and thoroughly mixing it, when it is replaced.

Each tube has an area of 80 square centimeters $=12.4$ square inches $=\frac{1}{50.555}$ acre, and the results are to be computed in tons of water evaporated per acre. The observations are to be taken for seven days and the results filled in below.

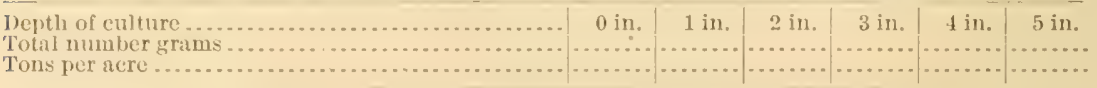

Tons per acre.

\section{Experiment $\boldsymbol{N}^{\top} \mathrm{o} .15$.}

EFFECT OF ARTIFICIAL MULCHES UPON EVAPORATION OF WATER FROM SOILS.

This experiment is conducted in a similar manner to the last, excepting that the tubes are all filled to the same level and used as follows: No. 1, control; No. 2, 2 mches sand; No. 3, 2 inches clay; No. 4, 2 inches muck; No. 5, 2 inches sawdust; No. 6,2 inches cut straw.

RESULTS.

Control. Sand. Clay. | Muck. ISawdust. Cut straw.

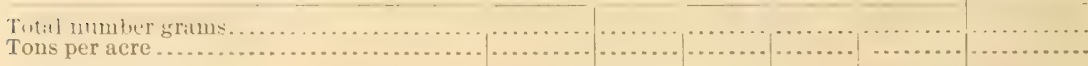


MICHIGAN AGRICULTURAL COLLEGE.

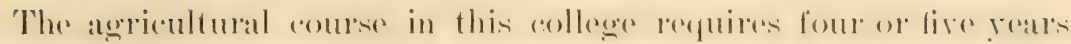
for completion, depenting on the prepatation of the ameliclates for admision, and leads to the degree of bathelor of seience. The entranes examinations for the five-year course cover the following subjecets: Arithmetic, geography, grammar, reading, spelling, pertmanshipe and history of the United states. The holdere of a tracheres's reptitieate, or eighth-grade diploma signed by a county commisinere and istued by a sehool following the course of study outlined by the state superintendent of public instruetion, will be admitted to the five-yeatr eourse without examination. For admision to the fouryear courses, students must hold diplomas from high sehook on an aleredited list, or must, in addition to the requirements named al hore.

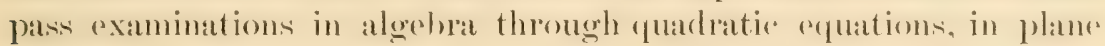
geometre in elementaly physies, and in English. Candidates for almision must bring testimonials of good chatrater, and must be not less than fifteen year's of age.

The entrance requirements also presuppose that the applicant has the ability to harmess and drive horses, to plow, harrow, math corn ground, drill, operate the mower, reaper, and farm implements generally, and to perform in a neat and workmanlike manner the details of regular farm work. A failure to pass this examination will not exclude from the college; another opportunity will he provided at the close of the second year to pass on these studies. If the student then fails he will he required to remain at the college luring the summer vacation hetween his second and third year's, or to work for the same period on some farm approved by the professor of agrieulture. II will recerive his final examination on the sul,ject at the leceinning of the junior year.

since both the four-year and the tive-year courses cover practically the same ground in agricultural subjects, only the four-year course will be described.

The course is rentered around instruction and practice in agrienlture and horticulture and the scienees directly bearing upon suecesiful farming. It includes the following ('redits: Agriculture, bo); agri culture or horticulture (elective), 5.!; anatomy, 10; Incteriology, 14; bacteriology (elective), 24; botany, 56; hotany (elective), 12; chemistry, t:; chemistry (elective), 12; civil engineering, 6 ; ciril enginerering (elective), 2t; drawing, 10; economies (elective), 12; English, 59: English (elective), 12; "ntomology, 12; geology (elective), 10; (rexman (elective), (6); history (elective), 12; horticulture, 51; hrgiene, $t$ : mathematies, 2:!; meteorology (elective), 12; molitary scienere and tacties, 22: physics, 20); physics (electwe), 12; political science, 10; psychology (olective), 12; sanitary sclence, 6; reterinary science, 5; ret-

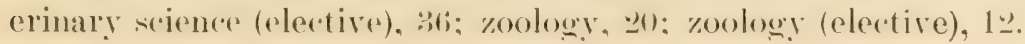


I'ntil the end of the first term. junior year, all four'-year agricultural studente pursure exactly the same studies, but for the remaining five terms they specialize in their technieal work, clecting either agriculture, including dairving, stock-feeding. soil work, and farm rops, or horticulture, inchuding regetahle culture, pomology, and floriculture.

Instrution in agromomy is given hy the professor of agronomy and one assistant in the serend and third terms of the freshman reare the first and sereond terme of the sophomore year, the second and thiret terms of the junior rear, and the first, second, and third terms of the senior year, and is supplenented hy instruetion in hotany, latereriology. and chemistry.

The courses in botany (aside from those bearing on forestry) for

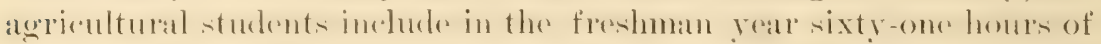
structural betany (eposs anatomy and morphologer of fruits and seeds) and thirty-theres hours of systemative botany: in the sophomore year

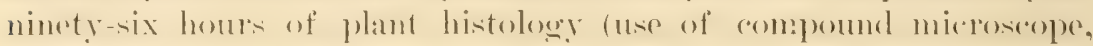
prepatration of tides. use of reagents. study of plant anatomy, (ete.) and thirty-thres hours of arology: one hundred and twenty-six hours of fumeri of exonomie importane during the first term of the junior frar: and forty-eight hours deroted to a study of grasises and weeds during the serond term of the junior yoar. A senior elective in plant physolegy has been amounced. Instruetion in botany is griven in the

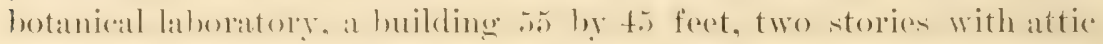
and basement. The hasement includes a liereproof room entaining

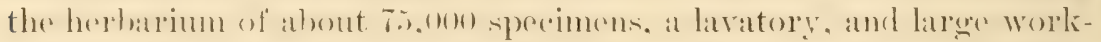
room for the preparation and storing of spercimens and boxes: the first

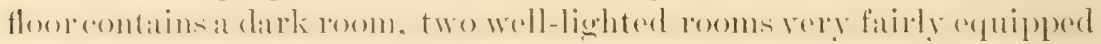

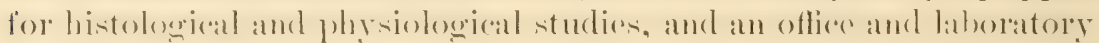

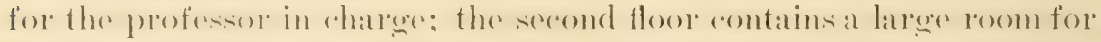
beginmers in hotany and for lectures. and a study and laboratery for

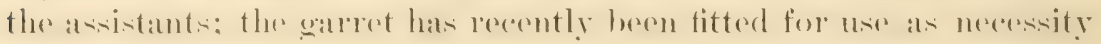
may require.

Batederiologeg is taught by the laboratory method, supplemented by

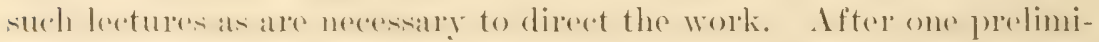
nary lecture course and two laboratory eomroses (tirst, morphologerial and coltural bateriology, and second, physiological bacteriology), the student may aleret duringe the winter term of the seniole yate a laboratory andw in hacteriology (ten hours per weok) deroted to the biolegieal consibleration of the soil. This work is griven in an new and

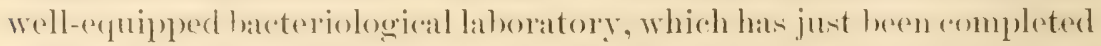
at a cost (exclusive of equipment) of $\$ 25,000$.

Instruction in chemistry includes general elementary chemistry (nimety-eight hours during the first term of the freshman year). (pualitative analysis (one hundred and twenty hours during the serend terme

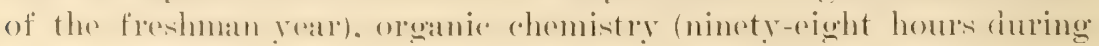


the tirst term of the sophomore year), and agrieultural ehemistry (sixty hours duringe the serend term of the sophomore year and sixty hours. elective, dering the sereond terme of the semiog year). The contre in

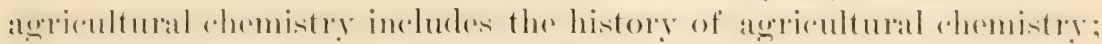
the comperition of plants, soureese of the oreanie constituents of plants. how to incerase their quantity and arabilabity: the soil and the influenes of physical ageneies on its ahemical comblition; the mature and arefion of the ash elements in plant gerowth; manures and manuring: intensive and extensive agrieulture, and conservation of fertility; the (hemistry of fodders and stock feodinge of repening of fruits and grains. The aim in these lextures is to state and solve the chemical problems of the farm. The chemieal laboratory building entains a

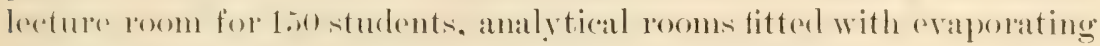

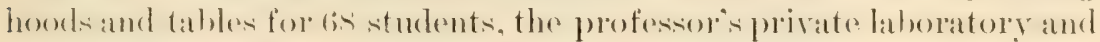
study, and a sulte of rooms for students in metallurey and quantitative (hemical amaly,is. and is well equipped with chemical apparatus and stores.

The courses in agronomy are introduced by a course of twenty lectures on the formation, character, and distribution of soils: the agencies still at work in soil formation and soil destruetion: and the (are reguired to be exercised to preserve the soils of agrientural districts. These lecetures are given during the last four weeks of the second term of the freshman year and are illustrated by samples of soil. rock, ate. and hy the stereopticon, and are supplemented by laboratory work and oral quizzes. During the third term of the freshman yoar, ten hours per week are spent in studying soils as regands their charateristies, functions, needs, and treatment in agriculture; dramage, its theory and practice; reasoms for the different operations of the farm and the tools used; the plamning of farm work, ete. Throughout this work the lantern is used to illustrate the talks and the student is taken to the tool room and to the field for observat tion. It is the aim to have quizzes at least as often as once per week.

Two hours daily of the first term of the sophomore year are deroted to lectures and laboratory work in agricultural physies, including (besides rural engineering and farm mechanies) laboratory work in the mechanieal analysis of soils, the determination of moisture in soils, green and dry fodders, roots and grains, and experiments in moisture and air movements in soils.

The subject of farm crops is given in lectures five hours per week during the second term of the sophomore year. In this course, "good seed and conditions affecting its vitality, general requirements for' suces-ful plant growth, conditions governing the time and depth of planting, rate of seeding, ote.. and the prineiples of plant implevement, are discussed. The history, distribution, general eharatereristics. 
adaptability, uses of the several farm crops and the best method of producing them are studied."

In the second term of the junior year the student may elect " agricultural experimentation." In this course one hour per day is given to lectures and individual work on the part of the student on the experiment station work and literature of this and other countries, the organization and work of the L'nited States Department of Agriculture. methods of experinentation, and the principles underlying the same. Each student is required in closing up the term's work to ontline an experiment along some practical line of live stock, dairying, soils, or crops, and to submit the outline to the class for eriticism and discussion. The experimentation is continued during the third term two hours por day. For example, the student olecting an experi-

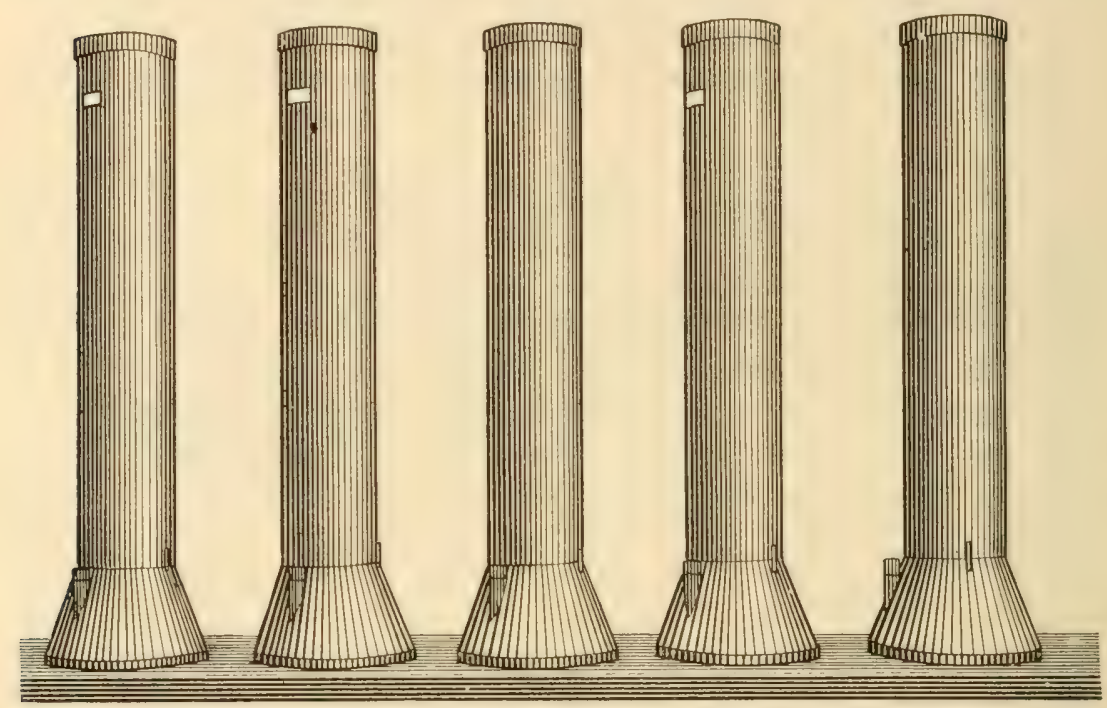

Fig. 2.-Tubes of gralvanized iron used to sturly effectivenesz of mulches upon moisture losses.

ment in agronomy, such as tests of forage crop mixtures, variety test of field crops, fertilizer experiments. ete. is allotted the necessary land, furnished team, implements. seed, etc., and is recpuired to carry through his experiment and report upon it.

"The object of this work is twofold. To the young man going hack to the farm it gives a training which enables him at once to pass upon the merits of any line of work described in station literature and to appropriate that portion of it which may he of value to himself; to the young man going into technical fields it gives a training which should give strength and reliability to his work."

In the senior year an elective in soil physice is offered. In this course ten hours per woek during the first termare deroted to lectures and laberatory work, cmbracing a study of the physical properties and 


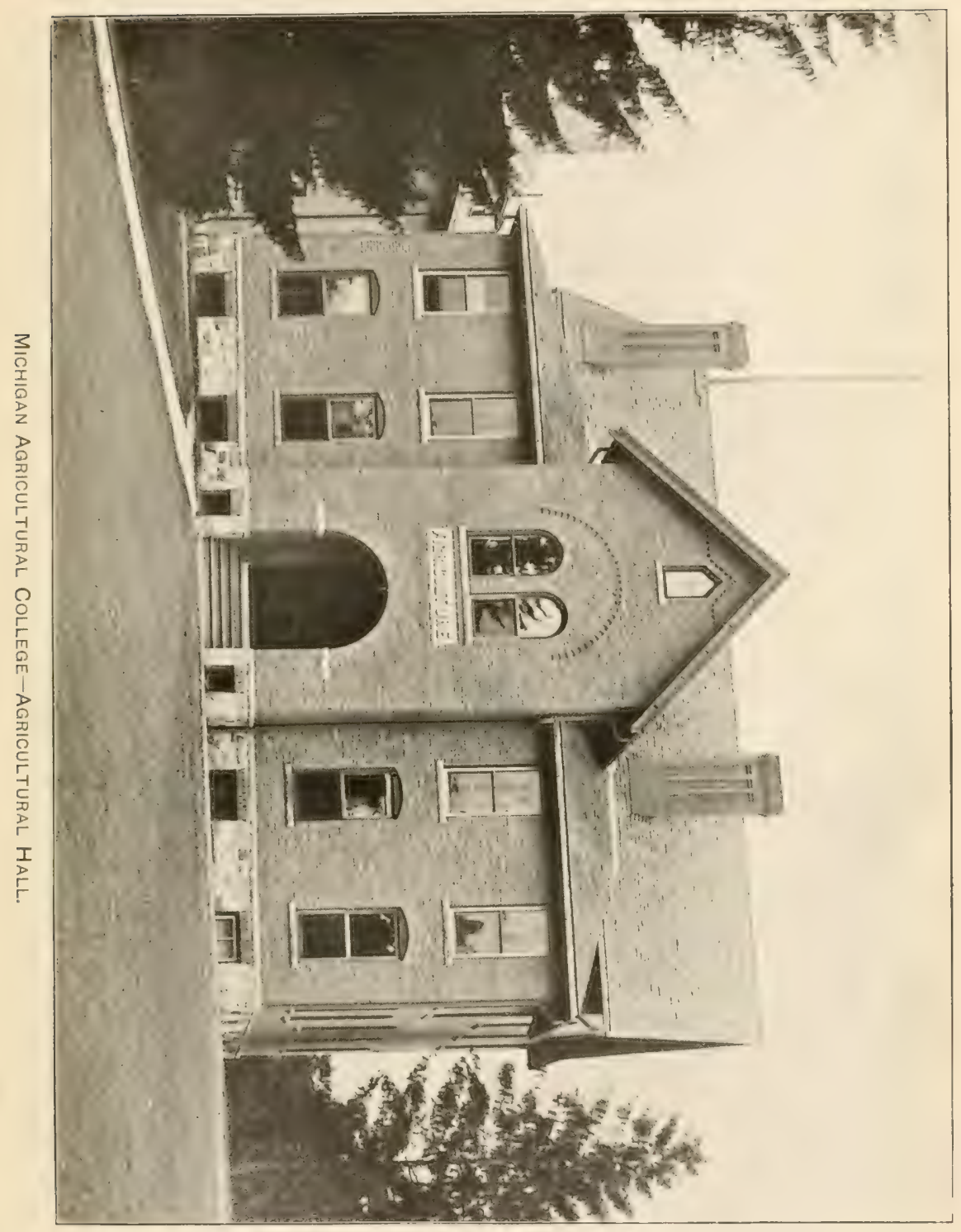





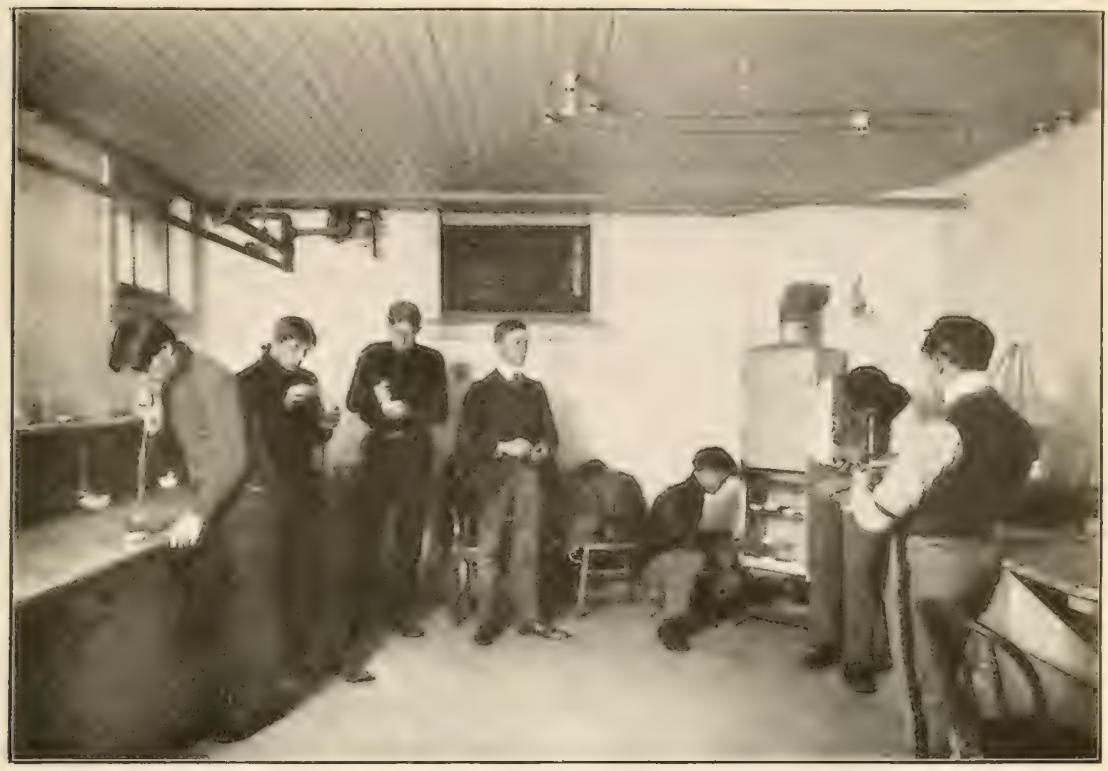

Fig. 1.-Michigan hgricultural College-Students Making Mechanical Analyses OF SOILS.

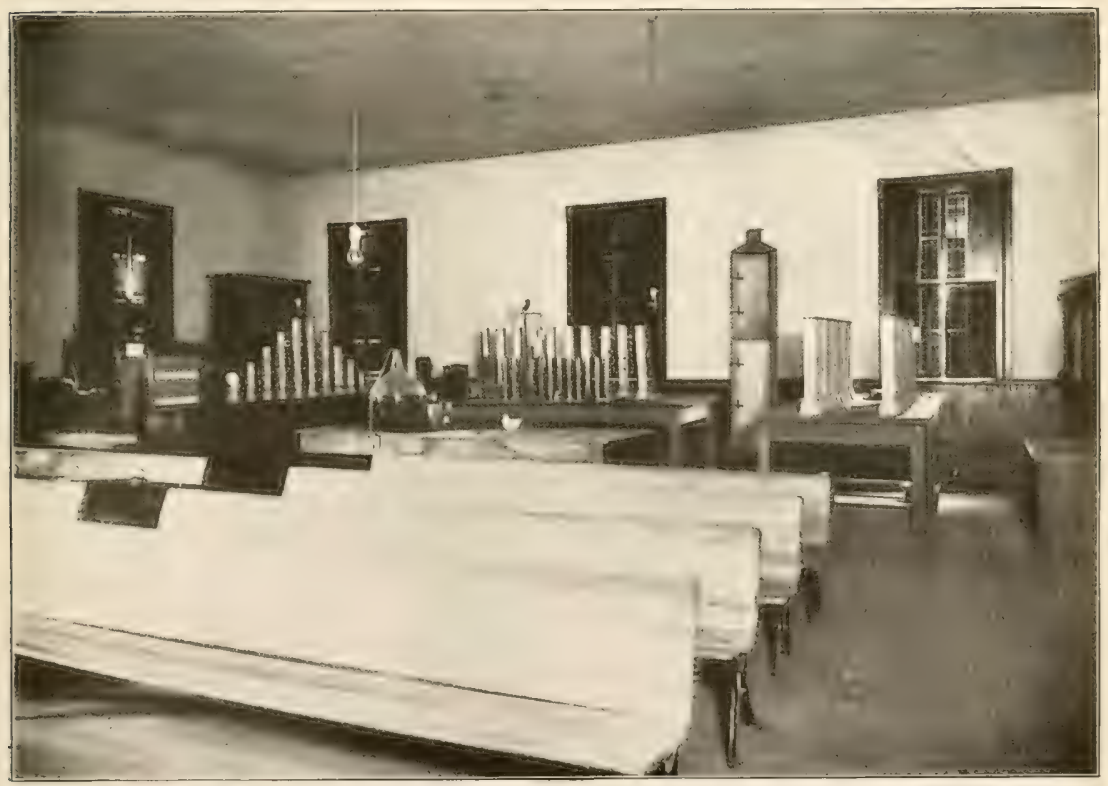

Fig. 2.-Michigan Agricultural College-Soils laboratory and Class Room. 

characteristies of soils, such as determining the speritiendaty, apparent specilie gravity, water movements. (ap)illarity, ote. Dhring the winter term ten hours pere week are devoted by the student fo origimal inverstigation work along some line atgreed upon bef ween the student and professor in charge. During thespring term ten hour's per week, seren weeks, are devoted to ad vanced work in soils. incholing lectures, lathorattory work, studying woluhle sitts in soils by the electrical method, the pore space in natural soils, etc.

The building in which the instructional and laboratory work in agronomy is chiefly conducted is built of brick, is 53 feet long, $5+$ feet wide. and two stories high, with attic and basement, and is known as Agricultural Hall (PI. V). The basement of this building contains a large laboratory for agrieultural physics, a small laboratory for mechanical analysis of soils (Pl. VI, fig. 1), storerooms, ete., and connects with a small plant house. The first floor contains offices, a dark room, and a large general lecture room provided with su square feet of hlackboard, two cases of wall maps, a stereopticon, and a 12 by 12 foot lantern screen. The windows of this and other rooms in the building are provided with eloth curtains and wood blinds. The lantern slides at present include illustrations of different phases of soil formation and soil destruction and of different kinds of farm machinery. New slides are being added. The soils laboratory, which also serves as a lecture room, is on the second floor of Agricultural Hall (Pl. VI,

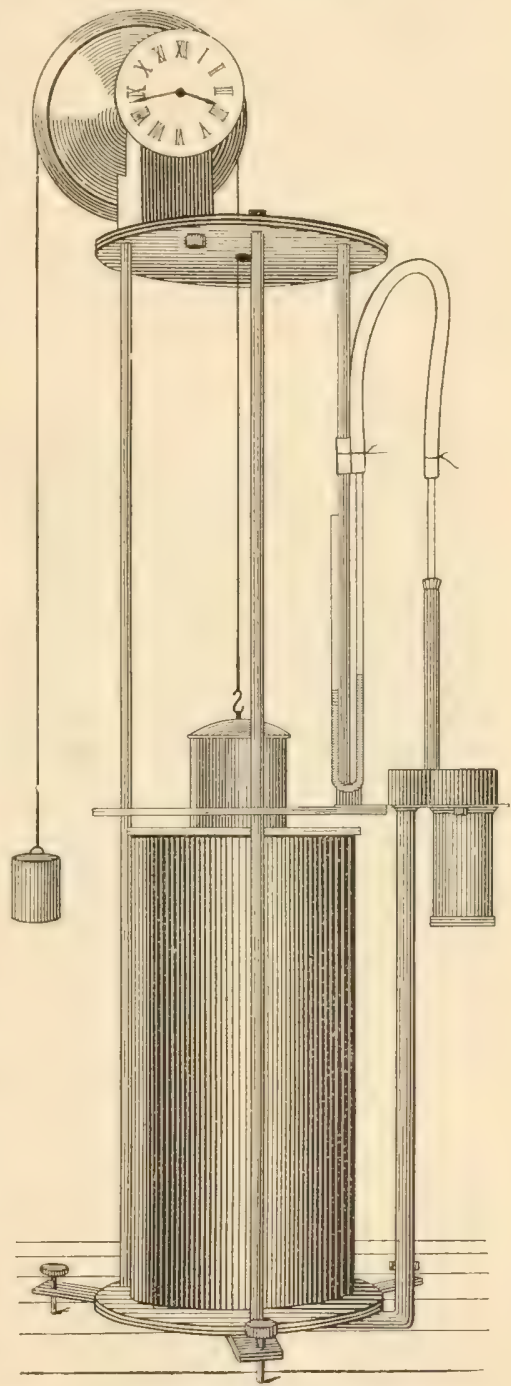

FiG. 3.-King's aspirator to determine the effective size of soil grains. fig. 2) and is supplied with apparatus ats follows: Four sets of galvanized iron tubes (fig. "2) for the study of moisture movements in soils and three sets of hrass tubes for the study of water and air morements (ligk. 8 and t) in soils: a " King'saspirator" (fig. :3) for determining the effective size of soil grain-: a " Whituer"s bredere" for determining 
the soluble salts in soils: apparatus for the mechamical amalysis of roils: a steam drying oven and a hot-ate drying oren (lig. (i); trays and "ase. sampling anger, and sampling tuhe for field work in soils; a torsion balanere and a number of other halances: four empound microserepes and one micrometer slide: a number of samples of typieal soils from other States. as well ats samples of Michigan soils, to which samplesadditions are being made as rapidly as opportunity permits: a

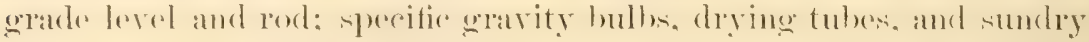
glass and rubber tubing and glassware. The room has about 120 square feet of blackboard.

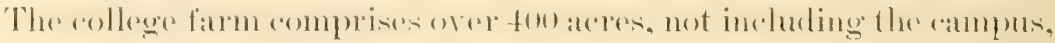
orehards. eardens. stock yards, and the experiment station plats. It is divided into twenty pasture, field, and wood lots. At present the several acreages are about as follows: Woods, 1t0; wild pasture, 30; tame pasture, 37; haty, 69; and roots, cereals, and forage crops, $1+1$ acres. The soil is a drift soil and ranges from a sandy soil to a fine (lay soil, all of which is interspersed with coarse graved and hatd heads and bowlders. The farm mathinery is up te date in crery particular and includes at latere enlleretion of modern types of implements and

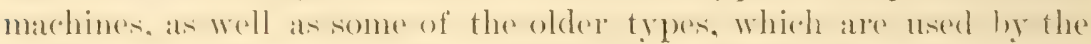
students in making comparisoms of draft. Work, effecet on soils. ete.

The library antains orer 21.0001 bound volumes and about 5.600 pamphlets. and is rieh in seintitie works. The tahles of the reading

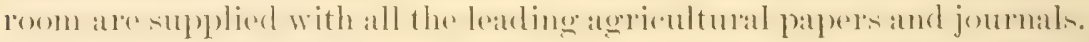
In matters conerening arops amd soils roferemere is mate first of all,

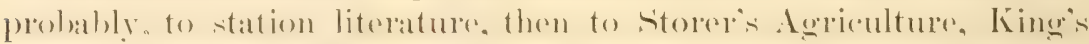

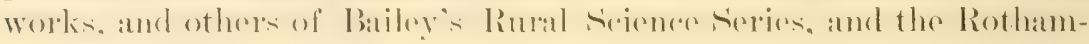
sted reports.

\section{ExIIIBIT No. 5.}

\section{A FEW OF THE PRACTICUMS IN AGRONOMY.}

\section{The movement of ar through different soils.}

Description of apparutus. - The apparatus used for the study of air movements through soils consists of an aspirator, as shown in fig. 4 , and 12 brass tubes 16 inches in height and having a diameter of 3 inches. These soil tubes are all filled to the depth of 1 inch with a coarse sand, and above the sand are filled to a depth of 12 inches with the different soils indicated in the table. By means of apparatus prepared for the purpose the soils are introduced into the tubes and packed so that any difference in the pore space in the soils must be due to the physical properties of the soil. It will be seen that the variation of size of soil grain, variation in the proportions of large and small grains, variation in amount of organic matter present, etc., must be the factors resulting in the differences in the rates at which the air moves through the soil.

Observe that we have not the conditions in the soil in the cylinders that we have in the soil in the field, and that with this apparatus we are studying only the effects resulting largely from the properties named. 
Erratur.-On parges 43 and 44 the cuts have been transposed, $i$. e., the apparatus shown on page $4: 3$ is for the study of percolation of water through soils and the apparatus shown on page $4 t$ is for the study of the movement of air through soils. 
Detritis of the macticum.-

1. With the rubber tube detached irom soil tuhes, lift the aspirator weight, allowing bell to fall to bottom of aspirator tank.

2 . Attach rubber tube to soil tube No. 1 .

3. Now earefully lower weight until it is just sustained hy presture of air upon the bell.

4. With watch note time required for the hame to pass over there livisions of the dial, recording time as indicated in a table like the one below.

5. In like mamer attach rubber tube to Nos. 2, 3, 4, 5, 6, 7 , and s and mote and recort the time required to pass over three divisions of the dial.

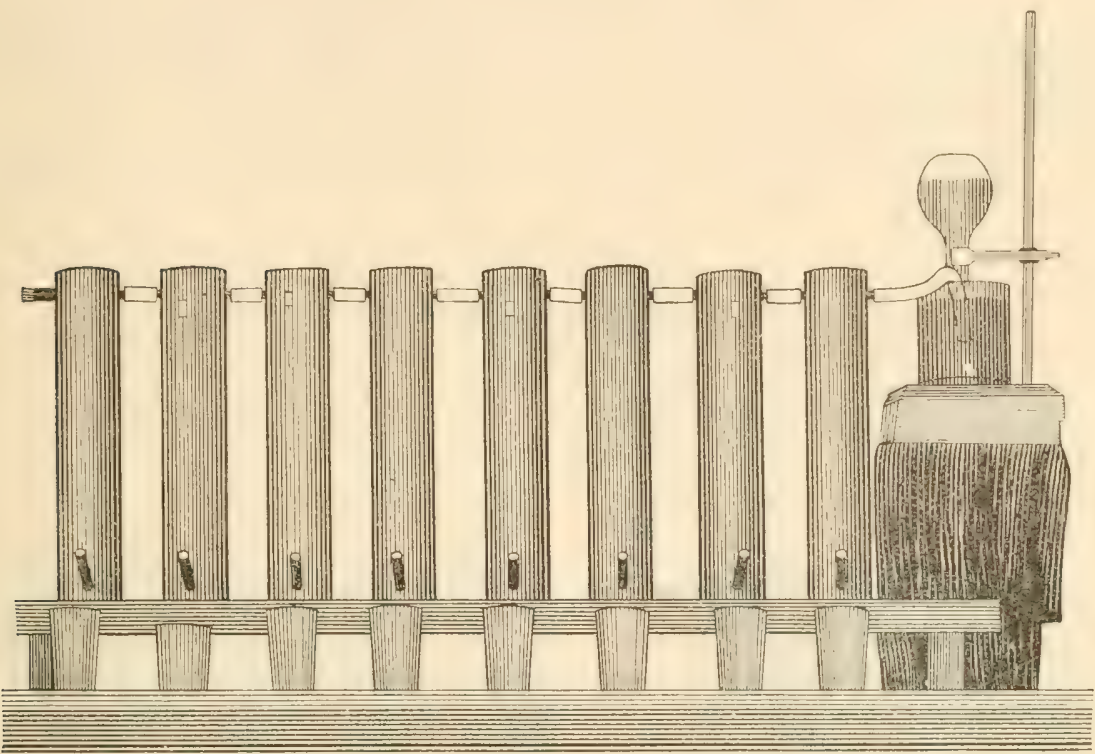

Fig. 1.-Apparatus used to study the movement of air through soils.

6. In like manner attach rubber tube to Nos. 9, 10, 11, and 12 and note the time required for the hand to pass over one division on the dial. Multiply this time by three and introduce in table.

7. Make computations and fill in as indicated in the table.

Sinil.

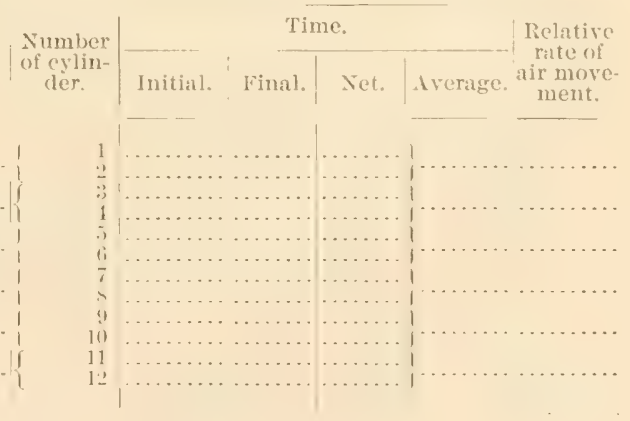


Percolation of water through different soils.

Description of apparatus. - This apparatus (fig. 5), consists of soil tubes similar to those userl for the sturly of the rate of air movement throush wils riffering only in having tubes at the top by which the series may be comnected by pieces of rubber tubing and supplied automationlly with water so that the hear or pressure in all the tubes can he kept constant. The tuhes are filled in the same mammer with soil as for sturlying air movements, and the rate of perolation depends upun the same fhysical properties of the soils as in the case of the movement of air.

Detrils of the practicum.-

1. See that the water supply is properly arranged.

2. Tare the glass or cylinder of each soil tube and record its weight in the proper place in a table like the one shown below, but do not return them immediately under the drain tubes.

$\therefore$ Remove corks from drain tubes and insert wire drips.

4. When water drops from all the wires, place the glasses and cylinders quickly under the drain tules. moting the time.

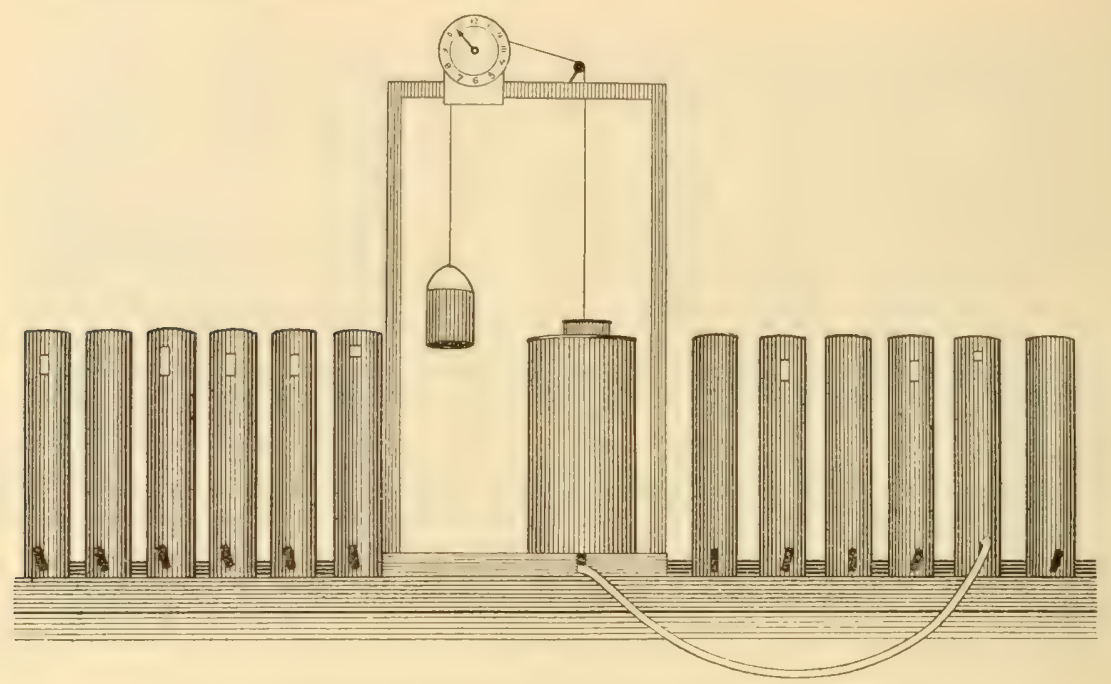

Fic, 5,-Apparatus used to study percolation of water through soils.

5. At the end of 45 minutes quickly remove glasses and eylinders.

6. Remove wire drips and insert corks in drain tubes.

7. Weigh glasses and eylinders with contents and record weights in the proper place in the table.

8. Make proper computations and introduce results in table.

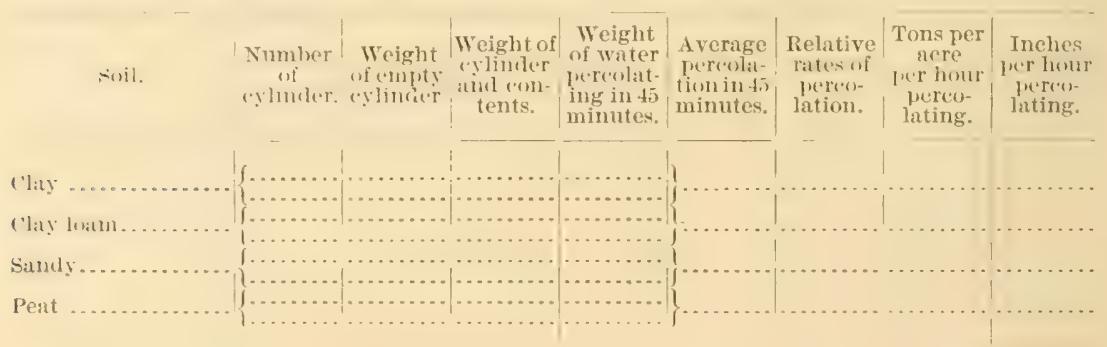


To take simples:

IN SOHL FREL FROM STONE.

1. Provide yourself with soil tube, mallet, and three soil tratys.

2. Having determined place for taking soil sample, pack the sirface of the seil

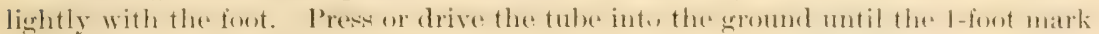
on the tube is even with the surface of the ground. Give the tube a turn. Place one hand firmly over the top of the woil tules to keepent air and with the other hand grasp and slowly withdraw the tube.

3. Remove cover from one of the trays, invert the soil tube, and allow the core to pass from the tube into the tray. Put cover on tray at once.

4. Return soil tube to the hole and press or drive down until the 2-foot mark on the tube is even with the surface of the ground. Remove as before and place the core in a second tray.

5. In like manner secure core from third foot and introduce into a third tray.

6. Pass to another point and as before secure cores of the first, second, and third fort, respectively, and introluce the cores into the trays eontaining the first, second, and third foot, respectively, already obtained.

7. Repeat until composite samples of four are obtained.

To dry samples:

8. Weigh each tray with contents, recording weights of each. Remove covers and place trays in drying oven.

9. After forty-eight hours replace covers and weigh trays with contents, carefully recording weights. Be sure samples are dry.

10. Rewove the dry soil from trays, wipe the trays carefully and weigh, recording weight.

11. Determine (a) loss of moisture from the soil, $(b)$ weight of dry soil, and $(c)$ the per cent of moisture in each soil estimated on dry weight of soil.

To take samples:

IN ROCKY NOIL.

1. Provide yourself with two soil trays and a spade.

2. Having determined place to take samples dig a hole 1 foot deep and a little wisler and longer than the width of your spade. See that one side is perpendicular. liemove all loose soil from bottom of hole.

3. With spade cut off a slice 1 inch thick from the perpendicular side of the hole to a depth of 6 inches, allowing soil to fall to the bottom of the hole where it should be yuickly crumbled amb mixed and freed from stomes larger than a small marble.

4. I'lace about one-half pint of this soil in one of the trays and cover. Remove the rest of the soil from the bottom of the hole.

5. With spade finish cutting the slice to the depth of 1 foot and proceed as above to mix and free from stone.

6. Place one-half pint of this soil in the second tray and cover.

7. Selecting another proint proceed as above to take samples of the first and second 6inches, respectively, and place the samples so taken in the trays with the samples of the first and second 6 inches already taken, respectively.

To dry the samples:

s. Weigh each tray with contents, recording weights of eath. Lemure anvers and place tray in drying oven.

9. After forty-eight hours replate covers and weigh trays with ontents, arefinlly recording weights. Be sure samples are dry.

10. Remove the dry soil from trays, wipe the trays carefully and weigh, recording weight.

11. Determine (a) loss of moisture from soil, $(b)$ weight of dry soil, and $(c)$ the per cent of moisture in each soil estimated on dry weight of soil. 
Determination of moisture in green crops, fodders, roots, and grains.

\section{r. - P'REPARATION.}

(a) Green crops. Cut sample close to gromel. Either fold or tie into short bun-

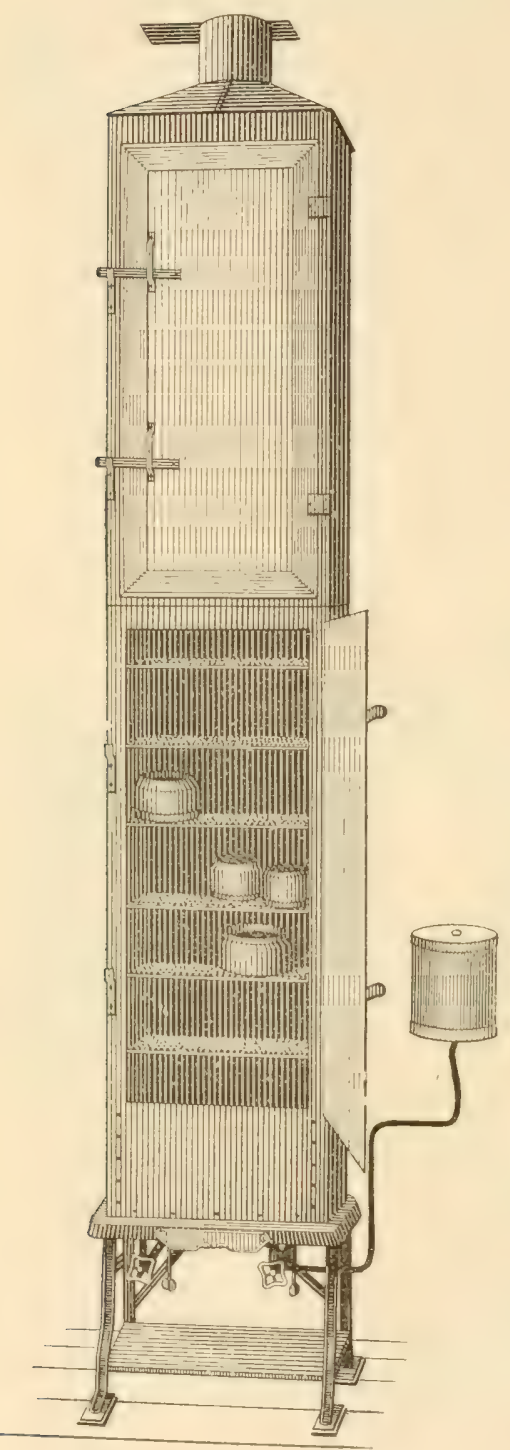

Fig. 6.-Hot-air drying oven. dles or cut into short lengths and put into a tray.

(b) Forkler (including hay and straw). Cut a quantity of the material in a feed cutter or with a knife, mix well, and fill tray with sample.

(c) Roots. Select one or more typical roots, elean with a good brush or wash and wipe carefully. With a sharp knife slice in tray quickly and cover.

(d) Grain. Place about one pint of cleaned grain in a tray. If it is desired to determine the moisture of corn in the ear select a typical ear having all of its kernels and place in tray.

$$
\text { 1I. - LABELIXY). }
$$

For the material placed in the trays it is suffieient to record the number of the tray.

Upon those materials not placed in trays a tag bearing your name should be placed.

$$
\text { II. - WEItiHTS. }
$$

You will need to determine: (a) Net weight before drying; (b) Net weight after drying; (c) Loss of moisture by drying.

With this data determine the per cent of moistme in the molriest material.

\section{IV.-THE DRYING.}

Place material in hot-air oven (fig. 6) having temperature of $120^{\circ} \mathrm{C}$. Drying should continue until materials have reached constant weights. This will usually be accomplished in twenty-four hours, but sometimes as much as fortyeight hours are required.

[Each student is given from six to eight materials to dry. In some cases he is required to go to the bin or field to pro". (ure them.] 


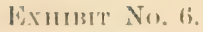

\section{EXAMINATION QUESTIONS IN SOILS AND CROPS.}

[This set of entestions covers in a general way the work done during the spring term of the freshman yeitr.]

1. What is meant by tillage? What are the chief objects sought in tillage? Tell quite fully how one of these objects is accomplished.

2. Explain the action of the common American plow. How does it differ from the English plow? Speak briefly of their relative merits. What objections to the common plow? What may we do toward obviating some of the bat effects?

3. Why do we cultivate? Describe an ideal cultivator and ideal cultivation.

4. What are some of the methods for removing the surplus water from land?

5. What will govern each of the following: Depth of drain, distance apart of drains, size of tile to be used.

6. What grade shonld tile drains have, what is the least grade allowable, and what precaution should be taken in laying a drain at such a grade?

7. How should laterals be connecter with drains? Where and how should silt wells be constructed?

8. What is meant by rotation of crops? Why do we rotate at all?

?. Ontline what you would call a good rotation, and give reason for the presence of each crop in the rotation.

10. When would you apply barn manure? At what rate, and why?

11. Speak of the value of clover as a crop. Why is it diffienlt to grow elover in llichigan? Tell how you would seeure a stand of clover.

12. The effect of lime upon soils? Why? Would you apply lime to the soils of Michigan? If yes, at what rate and why" If no, why not?

1:). What difference between a good truck soil and a good grass soil, and why is each soil especially adapted to its own crop?

14. In what way is the size of soil grain related to ( 1 ) the water holding capacity of the soil, $(b)$ the plant feeding qualities, and $(c)$ to the retaining of plant foods against percolation?

15. How does the amount of moisture required to grow a crop compare $(a)$ with our ammual rainfall, $(b)$ with the water content of our soils in the month of March? What objections to summer fallowing?

\section{COLLEGE OF AGRICULTURE OF THE UNIVERSITY OF MINNESOTA.}

Candidates for admision to the college of Agriculture of the L Li-

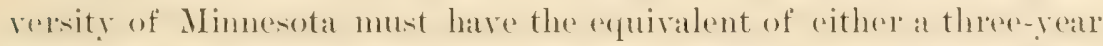
conrse in the school of agrienlture plus one year of work of high-

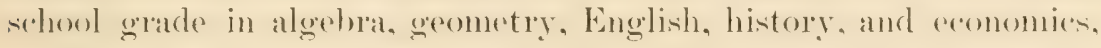
or a four-year course in a city high sehool plus one or two years in the school of agriculture. The sehool of agriculture is a terehnical high school, in which agriculture and subjects closely rolated to it litoely predominate. 'These sulijects include agrioultural hotany. rhemistry and physies, dairy rhemistry, agromomy, farm aceountis, animal hushandry, dairy hushandry, fruit growing, regetablo gatroning. otr. presented in a way to fit young men for sucessiful farm life or for entrance to the college of agriculture.

The college coure in agriculture is designed for those gradnates of the school of atgrienture and ifulents irom wher institutions equally well prepared who de-ire 
fuxther instruction in practical agricultural science, in the sciences related to agriculture, and in literature and the arts. Since all students who enter this course have hat the terhnical, scientific, and general work offered in the school of agriculture, the college course includes only advanced work of a collegiate grade. This course designs to efticiently prepare students for either farm life or for the work of the agricultural specialist. It emphavizes the importance of plant and animal production and the upbuilding of rural homes and farm life, while the biological and physical sciences are made prominent.

Following the four years of preparation in practical agricultural lines in the school of agrieniture, the freshman and sephomere gears are devoted largely to the stuly of

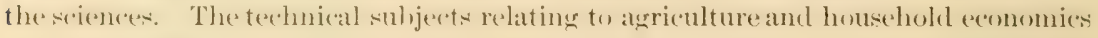
are mainly offered as electives in the junior and senior years, when the freedom for

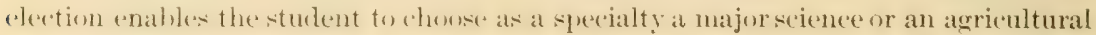

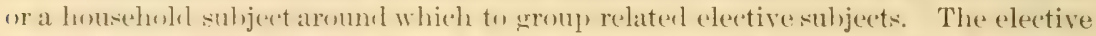
coureses luring the last two years give an olymertunity for further culture in literary and philosphinical lines and for hecoming more proficient in seientifie researeh work in some of the many problems pressing for sulution in the development of the state and national agrienlural experiment stations. The instruction in the varions technieal arrientural and lunselubld divisions in the college course is for the most part a continuation of the work in these subjects in the school of agriculture, each subject heing treaterl imon a more terhnical standyoint. Stulents who have first graduated from the agricultural school are ready in their junior and senior years to elect specialties for study and research work along lines in which they hope to work after graluation.

The suthect in the school of assiculture which more expecially prepate for the collegiate work in agromemy are angicultmal chemistry,

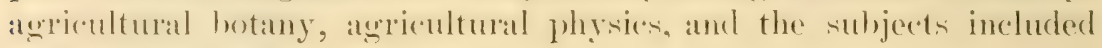
under the title of agriculture.

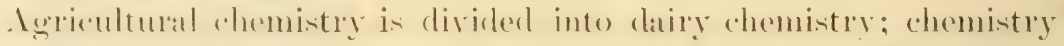
of fools, soils, atrd fertilizers, and domestic chemistry. I'nder the title of soils and fertilizers the student receives instruetion in the composition of sofis and their properties. the sourees of plant food, the kinds

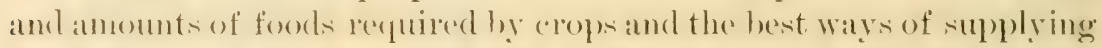
these demands. the varions forms in which plant food exists in the soil, farm manmes, their uses and action mpon the soil, the income and outgon of fertility from the farm, soil exhaution and soil improvement, the rotation of (rops as hased mpon the ehemistry of soils and the principles gorerning the conservation of the fertility of the soil. Iaboratory praretice forms am important feature of all the work in agricultural chemistry.

Agricultural hotany is tamght with special reference to its hoaring upon the ereryday problems that present themselves to the farmer and the gardener. By means of flowers and plants from the greenhouse and nursery studind under the simple and the compound microse(o)e. studentsare givon a clear idea of the general principles of plant structure and vegetable physiology.

In agricultural physies the general principles of physes ale taught, speral stress heing liad upon those principles which to the greatent extent enter into the husiness of the firmer. Shout half of the time 
is aevoted to experimental work which includes appillarity of soil: diflusion and osmosis of gases and liquids; heating, lighting, and ventilation; farm machinery, in particular pumps, eveners, pulleys, milk testers, contrifugals, incubator's, windmills, steam and gatsoline engines; frietion and lubriants; tensile strength of wire and binding twine of different grades; lightning and lightning protection.

The work designated "agriculture" in the sehool of agriculture includes (1) " introductory agriculture- soils; selecting and planting farms; subduing the fields; drainage; irrigation; fences; roadis; buildings; water supply; groves and introductory lessons concerning farm business, farm life, and the relations of general seience to agriculture;" and (a) field (copss and farm management, comprising instruction in remodeling farm plans, production and management of farm manures, rotation and hatndling of field (ropse, care and use of pastures and meadows, weeds and their destruetion, and the laws of heredity and vatriation in plant breeding, together with instruction in methods of breeding the leading field crops.

The college course in agronomy includes soil physies, field crops and seed, and plant breeding. Instruction in soil physies is given in the divisions of agricultural physices and agricultural chemistry, while that in field crops and seed and in plant breeding is given mainly by the professor of agriculture.

Lnder the head of field cropss and seed are considered the botany, cultivation, use and place in the rotation of the various cereal, forage, root, fiber, sugar, and miscellaneous crops. special attention is given to the suljects of permanent, rotation, annual, and shift pastures and to soiling "rops; to permanent and rotation meadows, and to the production and preservation of all kinds of dry-cured and ensiled fodders. A thesis on one or more field (rops is required of each student.

The work in plant breeding includes instruetion on such subjects as heredity, variation, science of hreeding, breeding as an art, improvement hy nature and under scientific experimentation, securing foundation stockis, value of very large numbers, immense value of the ocensional individual which ean transmit qualities of peculiar value, use of an ideal, use and misuse of the seore card, intrinsic qualities, fancy points and distinguishing marks, pedigree records of prepotency, fundamental principles underlying the arrangement of the record books, bibliography and terminology, study of the literature of breeding. Attention is alco given to the botany of the reproductire organs of tield crops, field-crop mursery management, producing new qualities by hybridizing and hy change of enviromment, hybridizing versus crosibreeding, in-breeding and self-fertilization, originating varieties and improving standard varieties, methods of disseminating new varieties, seed and plant introduction, experimentation in the theories relating $26777-$ No. $127-03-4$ 
to heredity, rariation and practical hreeding, seed growing as a farm business, seed merchandising.

Elective practicum give opportunity to gain practical experience, to acquire greater manual dexterity in doing farm work, to secure pratice in conducting experiments, and to gain experience in teaching agricultural subjects.

Agronomy is taught in dairy hall (Pl. VII, fig. 1) in temporary quarters which include one good recitation room, offices, and laboratory room. There is also a seed-breeding laboratory which furnishes facilities for special instruction in field seeds and in lahoratory work in plant breeding. The college posisesses a stereopticon with several hundred lantern slides, including illustrations of crops. implements, machinery, processes of drainage, ete.; imported models of wheat and of clover flowers and seeds; many charts of root systems and illustrattions of floral organs which have been drawn at this institution; also maps and designs of farm plans, both for laying out new farms and for reorganizing old ones. Several hundred pasteboard boxes zt inches long, 13 inches wide and 5 inches high, such as tailors use for suit boxes, are anmually filled with hundles of weeds, grasses, and forage crops. These serve in the classes for material to tear apart, examine the seeds, and get acequinted with the general appearance. Seeds are also preserved in bottles. The collection of farm marehinery in use at the university farm is supplemented hy collections on exhibition at the state fair grounds, adjoining the farm, and at warehouses in sit. Panl and Minneapolis.

One unique feature of the oflice expupment is a special index filing atar. Here are collected newspaper elippings, manuseripts, and references to literature in the library. These are put on sheets, $5 \frac{1}{2}$ by sit inches, separated by division cards, and arranged under at scheme similat to that used by the Office of Expreriment Stations in classifying special index ards of the station literature. This filing case now contains much material and is referred to constantly by students in the college course in writing essays and theses in connection with their dass work. Each student who writes a thesis on a farm (rop or other subject is required to furnish a copy for this filing case, and to include any bibliography he has been able to collect on that subject. Thus the students are aswisting in building up the contents of this filing (ase and it is recognized by them as very valuable.

No text-hooks are as ret in use. instruction being given ahmost entirely by lectures. The agricultural library now contains 0,000 books and about 6,000 pamphlets, including reports and bulletins. Asicle from the large number of pamphlets and other publications of the different angicultural institutions and sorieties, a large number of the more important technical and agricultural magazines are kept on file, bringing together all the agricultural literature of any importance. 


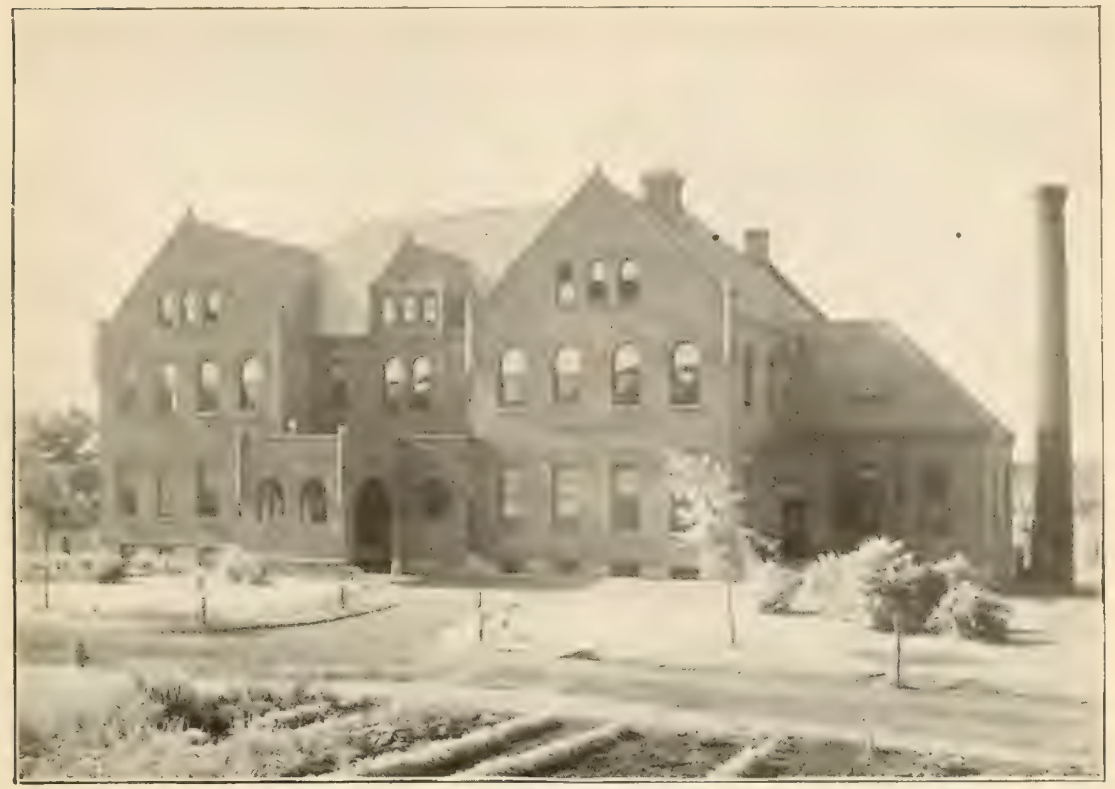

FiG. 1.-University of MinNesota-Dairy HaLL.

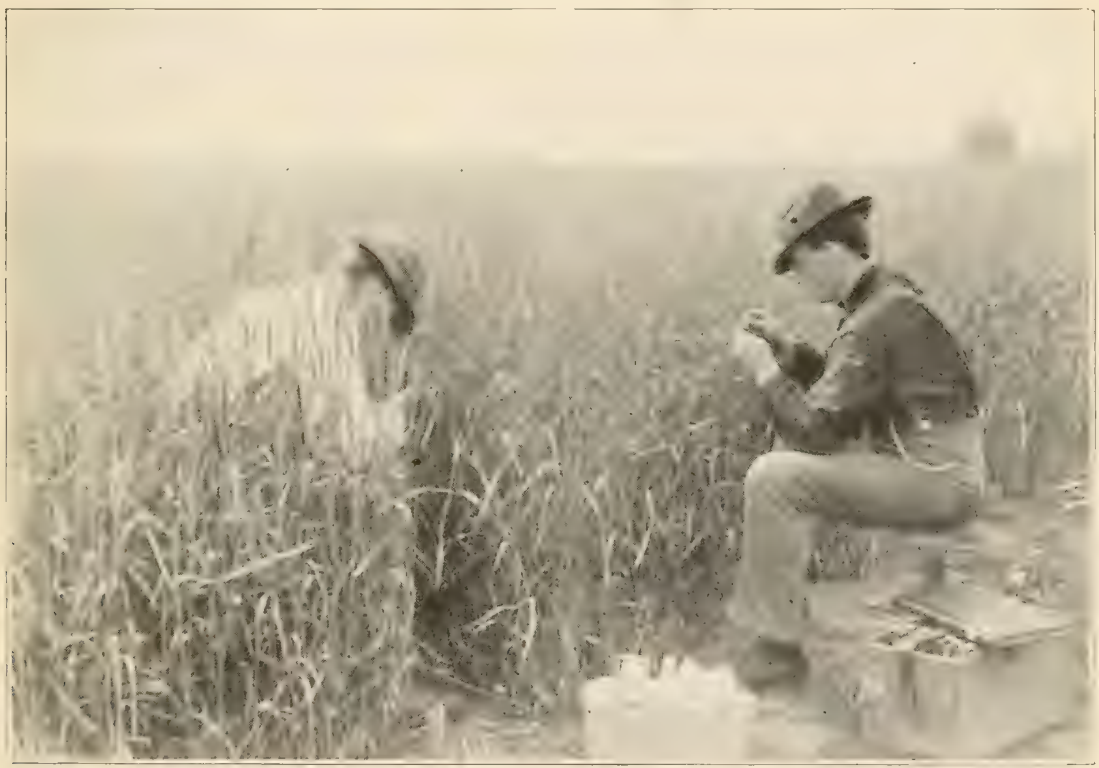

Fig. 2.-University of Minnesota-Emasculating and Cross Pollinating Wheat. 



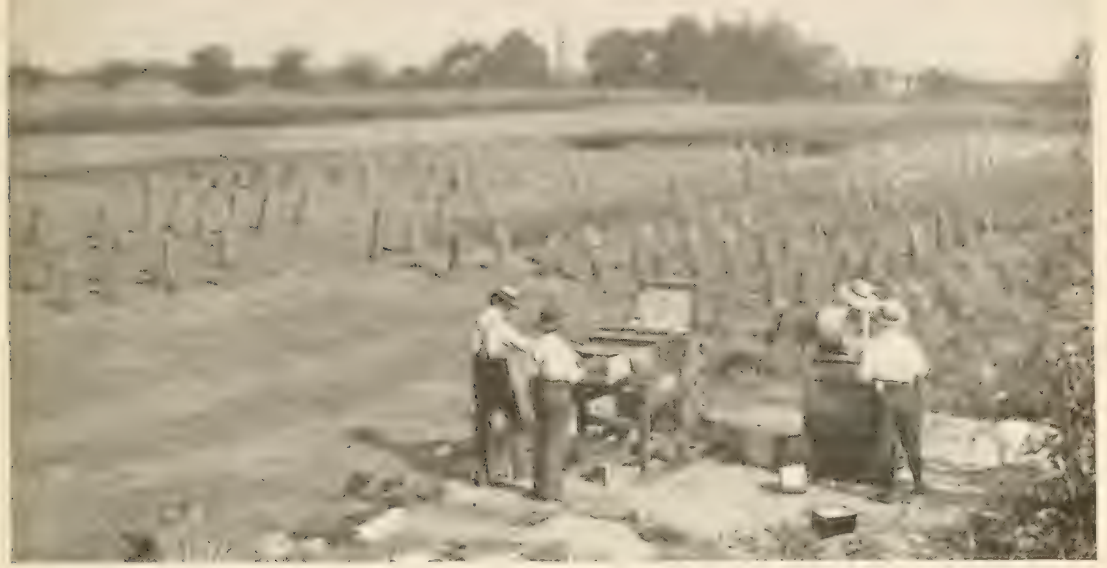

Fig. 1.-University of Minnesota-Centgener Thrashing MAchine and FanningMILL SEPARATOR IN USE IN THE FIELD CROP NURSERY.

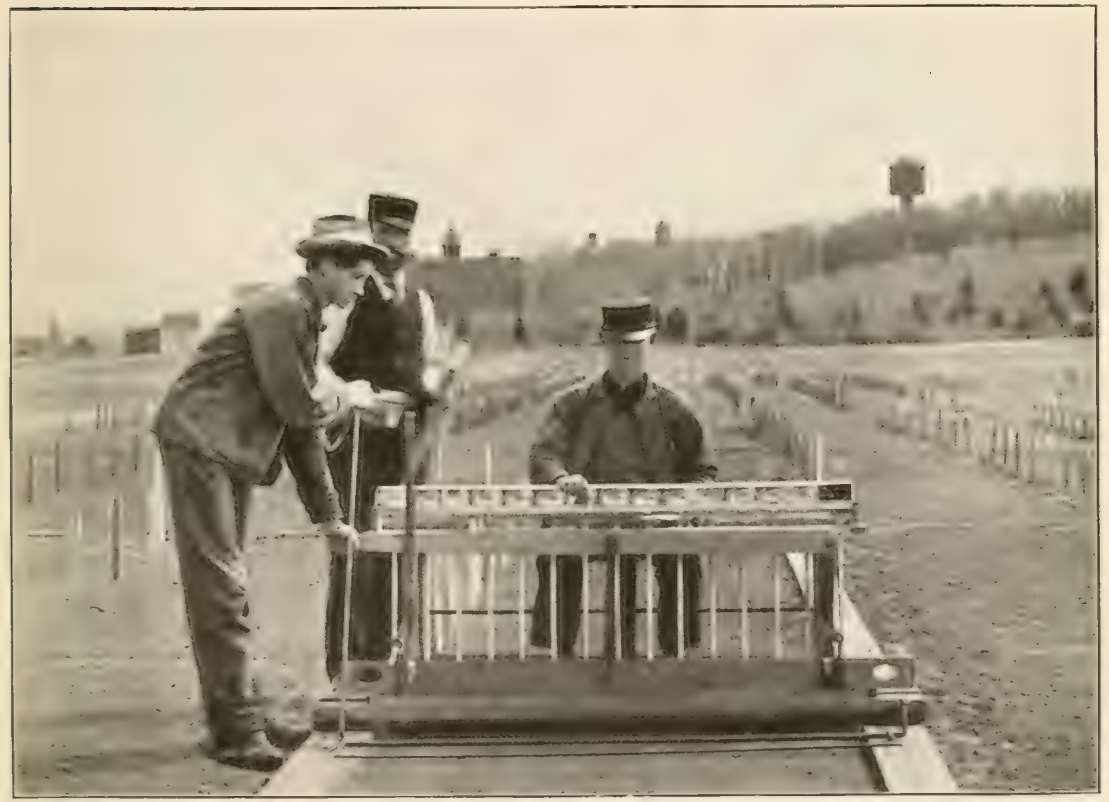

Fig. 2. - University of Minnesota-Machine for Planting Grain in Nursery Beds. 



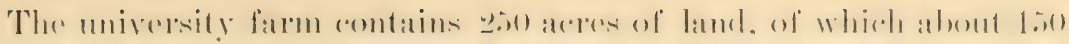

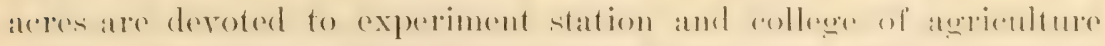
work. The soil is a mixture of rlay and sand, and is werll arlitpted to the various usese to which it is put. On the portion of the farme nesed

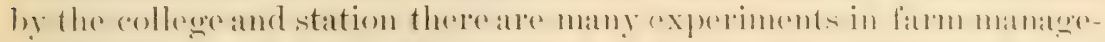

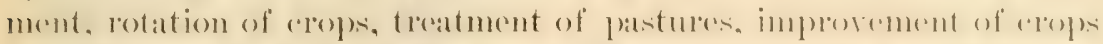

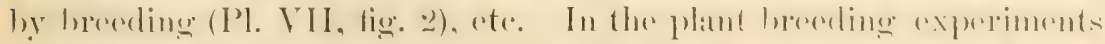

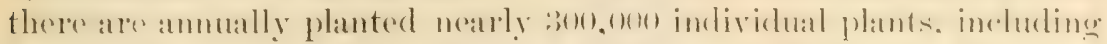
grains, clovers, root erops, ete., and for much of this work special machinery has been devised (fig. $T$ and Pl. VIII, figs. 1 and 2).

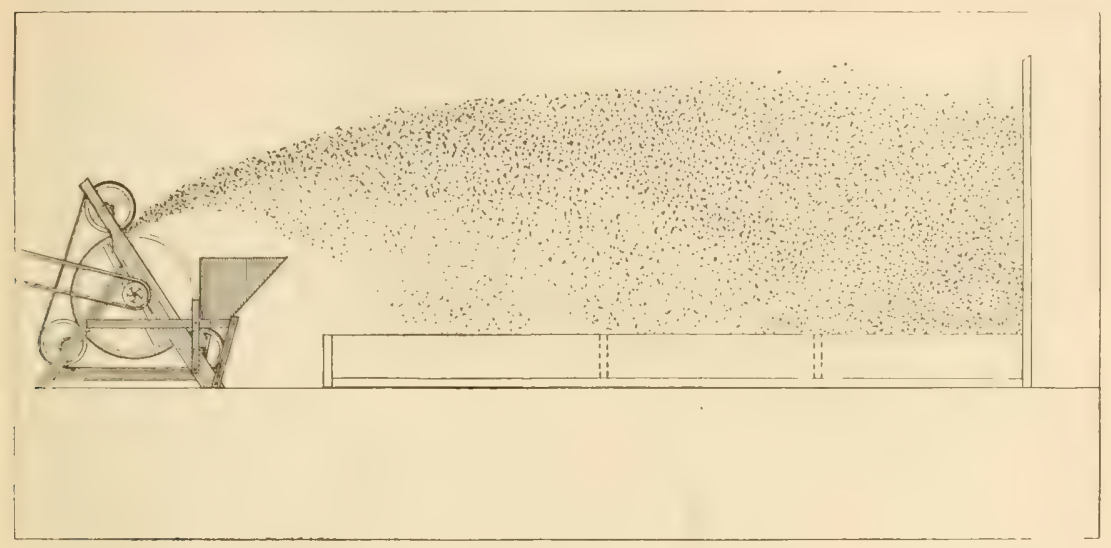

FIG. 7.-Centrifugal secel-grading machine.

Students who make a specialty of agromomy asist in these experi ments. Farms in the vicinity serve as a hasis for designing farm plans and working out problems in farm management.

\section{THE UNIVERSITY OF NEBRASKA.}

The industrial college of the Lnirersity of Nehnaska oflers sereral four-year agricultural groups (courses) leading to the deegree of hachclor of science-at technical group) at general group, and two special gromps. The technieal gromp is intended for graduates of the threereatrente in the school of agriculture. "The studies in the general groups are arranged to meet the needs and requirements of those students whose primary object is a hroad and general education." Those in the special groups are for students " fitting themselves to be instructors in agricultural subjects or to be experiment-station worker's." and "have been plammed and roordinated to enable students to direct their work so as to meet their individual needs and preferences." Candirlates for admission to the general and special groups must present certificates from accredited schools, academies, or colleges. of must pass examinations (1) on the following required subjecels: English, four years of language (ancient or modern or hoth), algehra througin 
logatrithms, plane and solid geometry and clementary botany, ehemistry, and physies: and (*) on a suffieient mumber of the following subjects for at total of 11 credits: Language, history, manual training, physical seiener, natural science, plane trigonometry, mechanical drawing. physiology and hygiene, physiography, civies, and politieal economy.

*All the courses in the first year of residene are prescribed, and form the common bases of hoth the general and the special groups offerend." The courses included in this year and the number of hours per week for wath rourse are mathematice 5. modern language t, physies: English ״, chemistry 2, military drill 1. The work in chemistry includes "a careful study of the oecurrence, methods of preparation, and properties of the common elements and their chief compounds." After the first year the courses are mostly alective. At least to per cent of the work of the last three years is taken in agrieulture and rhemistry or agrialture and botany, but " no student shall take or receive credit for more than forty hours work in any department during his undergraduate course."

Aeronomy at the Eniversity of Xehraskit " includes on the instruetional side the subjects of soils, field cropss, farm management, and the care and use of farm machinery." The conre in soils includes the following: The origin, deposition, and natural transportation of soils; physeal and rhemical constitution of soils and subsoils: influence of the size of soil grains on the rate of solution of plant food, drainage, acration. Water storagere capillarity, ete: forms in which water exists in soils: movement of water in the soil: soil temperatures: eraporation of water from the soil; methods of soil treatment for conservation of soil moisture: the rignitienere of a chemieal analysis of soil; fixation of fortilizing materials; nitrification: availability of plant food: tillager, reasons for tillagere afferet of drifting, effect of plowing wet or dry soil; subsoil plowing, water-holding power of loose and compate soils: disking, listing, ete.: the application of harnyard and geren manures and commeredial fertilizers. Given by the professor of agriculture.

This is followed by - field crops, their general emposition and their relation to the all and soil; useful and essential ingredients of the ash of plants; functions of the ash constituents of plants and the formation of plant suhstance: functions of the roots, stems, and leaves of plant:- the breeding of cereals; a treatment of each of the principal field crops, womewhat aceording to the following scheme: C'haracteristirs, varieties, vitality, (limate, soil, manures, tillage, seeding, eultivation, harvesting, preserration. position in rotation, uses. (iiven by the professor of agriculture."

Following these two courses is a labolatory course in the "Properties of soils." contimuing throughent the year and given by the prefessor of agriculture and the instructor in agriculture. 


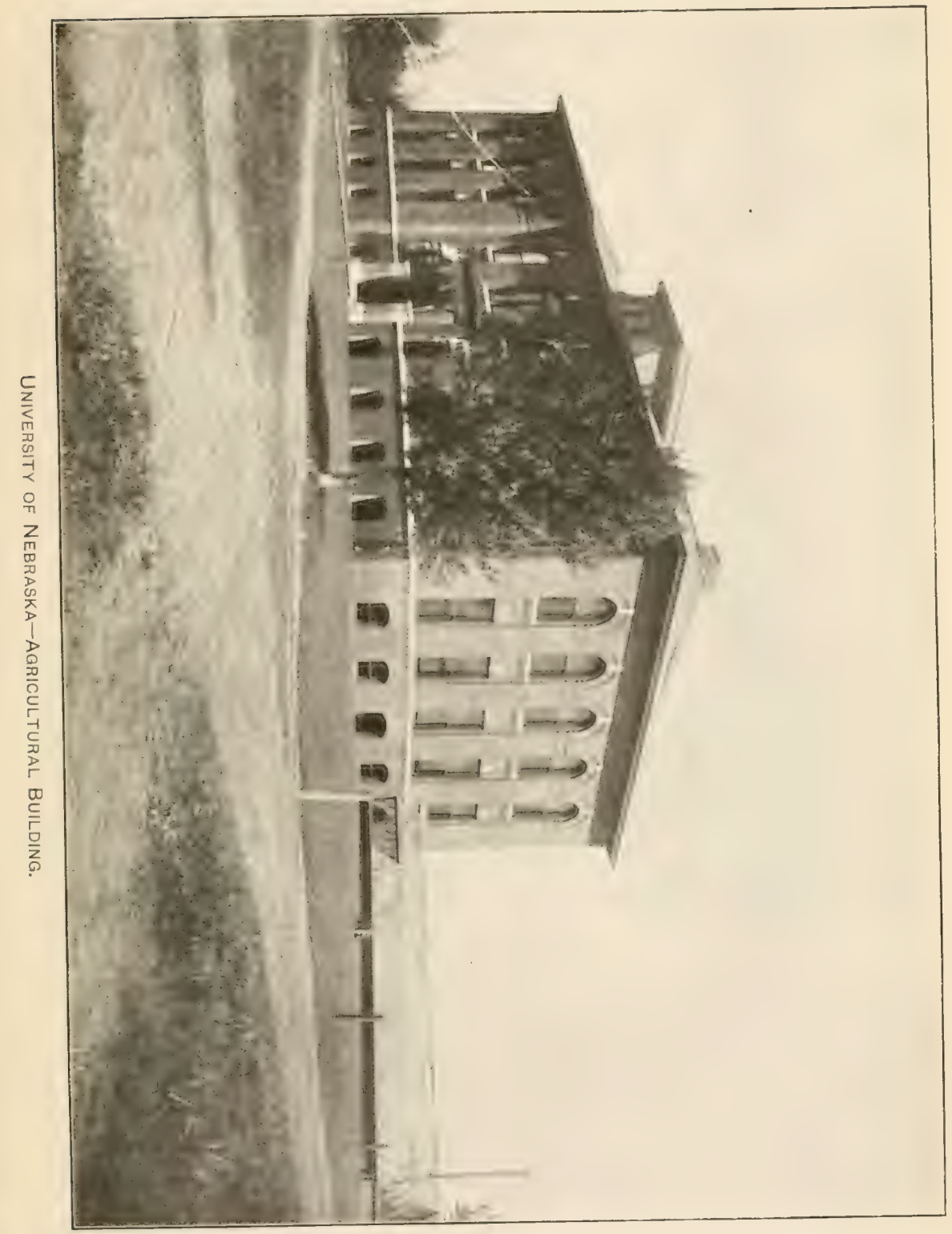





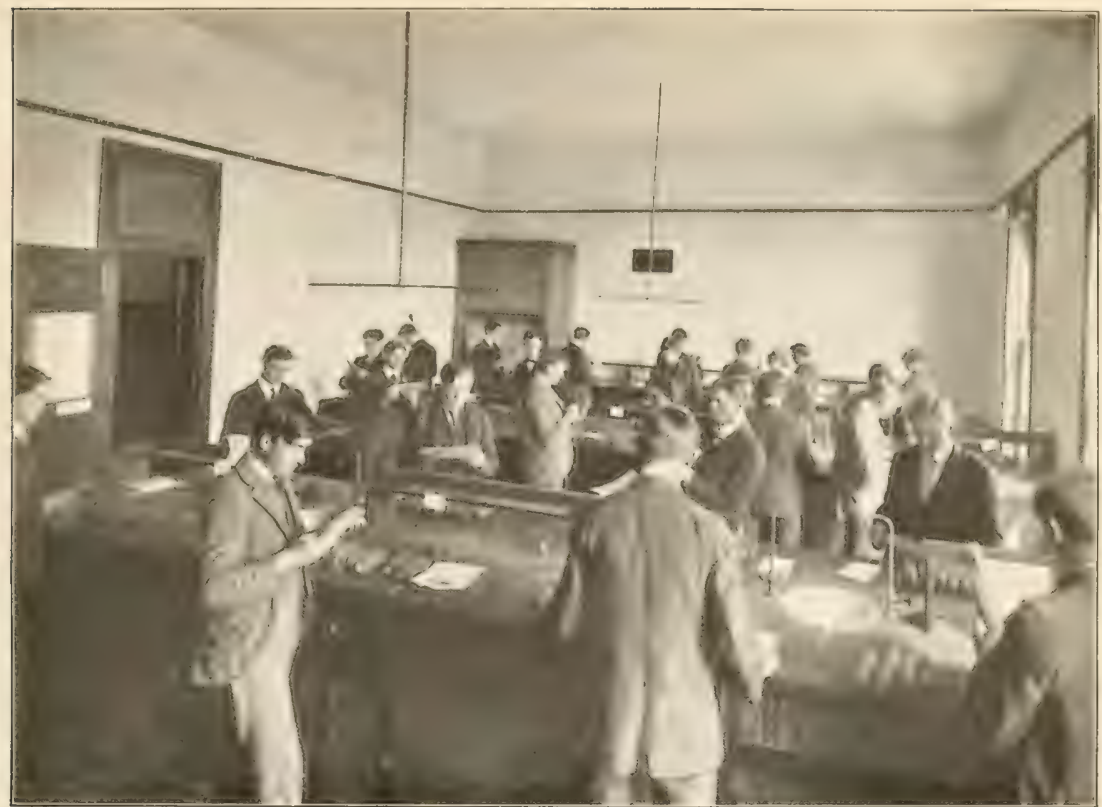

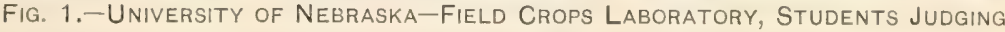
SEED CORN.

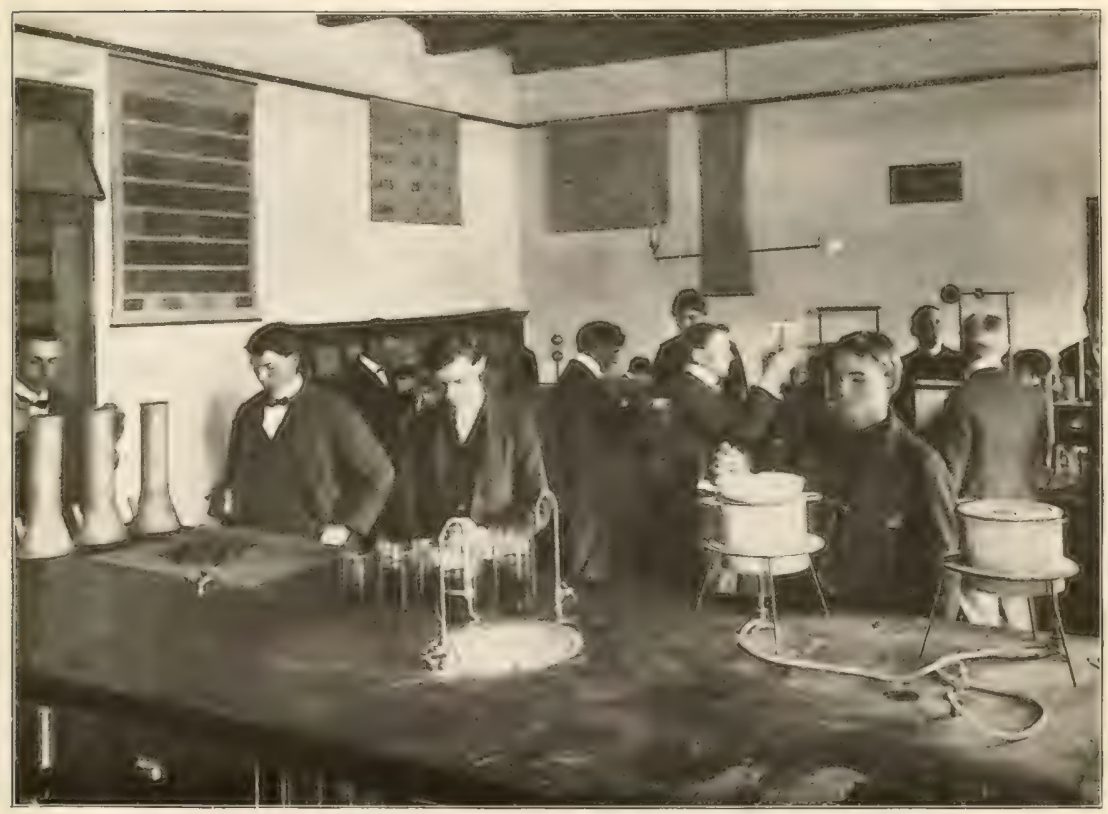

FIG. 2.-UNIVERSITY OF NEBRASKA-SOILS LABORATORY. 



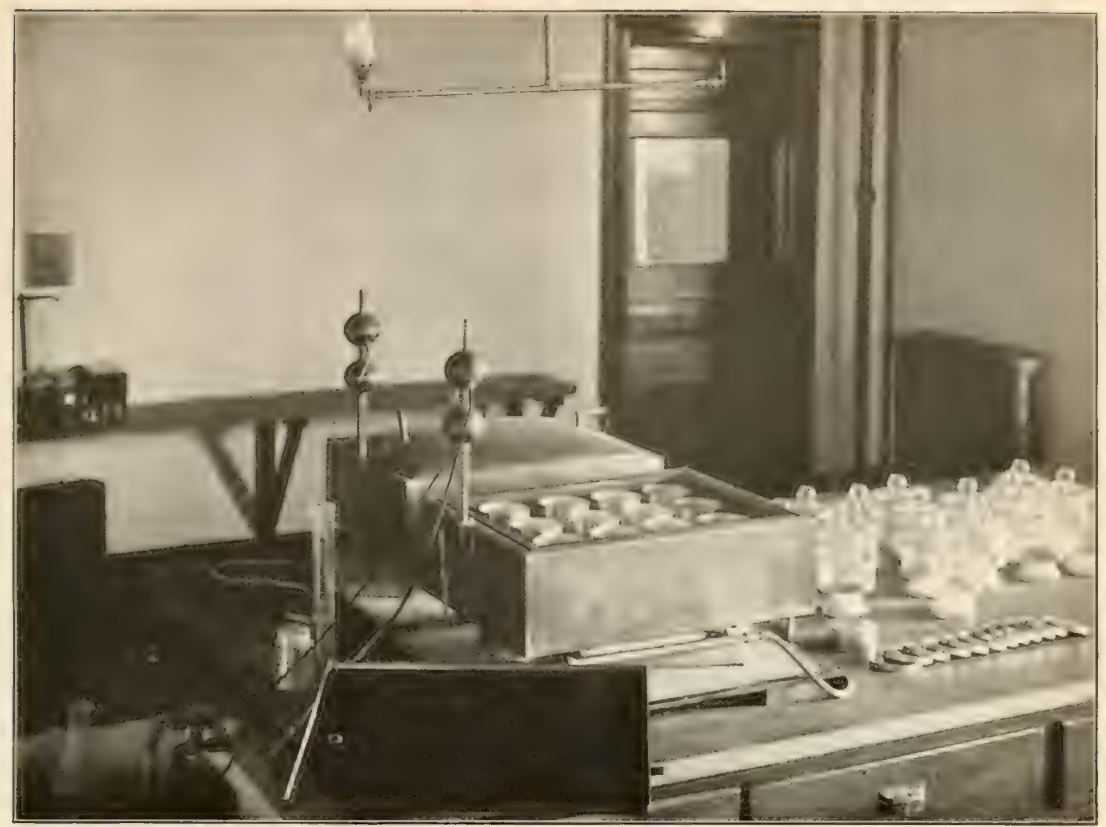

Fig. 1.-University of Nebraska-Apparatus for Making Determinations of Soll MOISTURE.

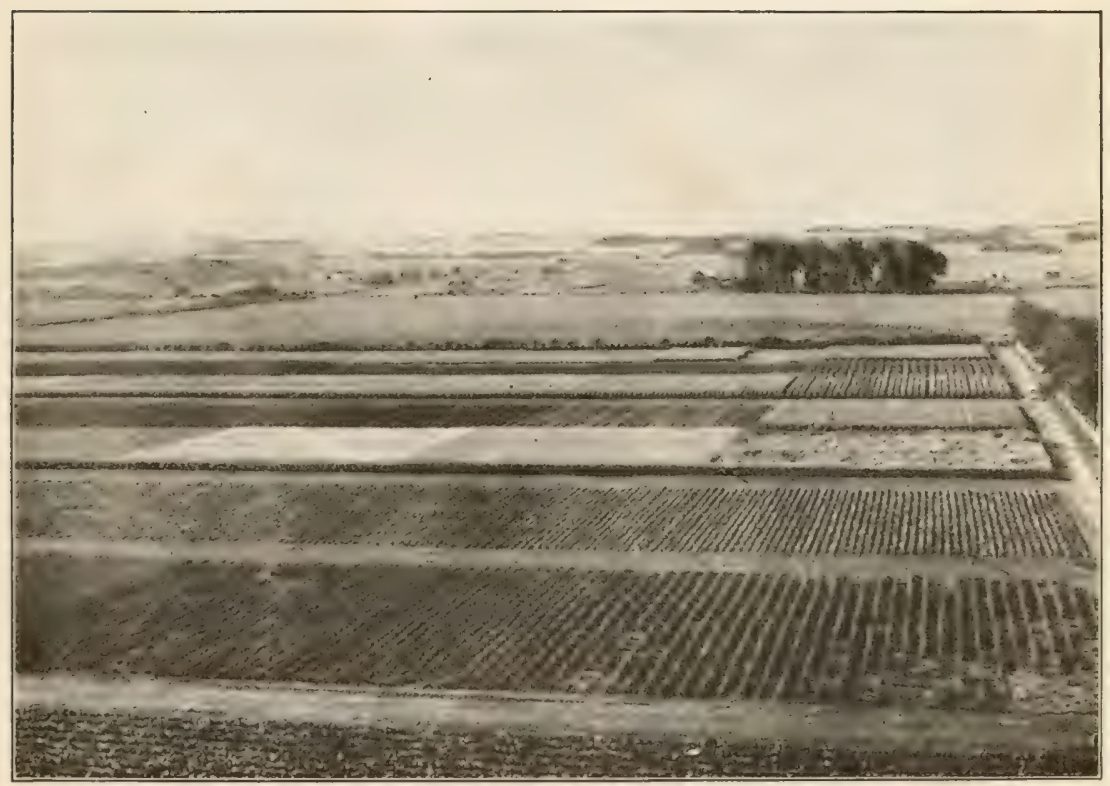

Fig. 2.-University of Nebraska-Experiment Plats. 



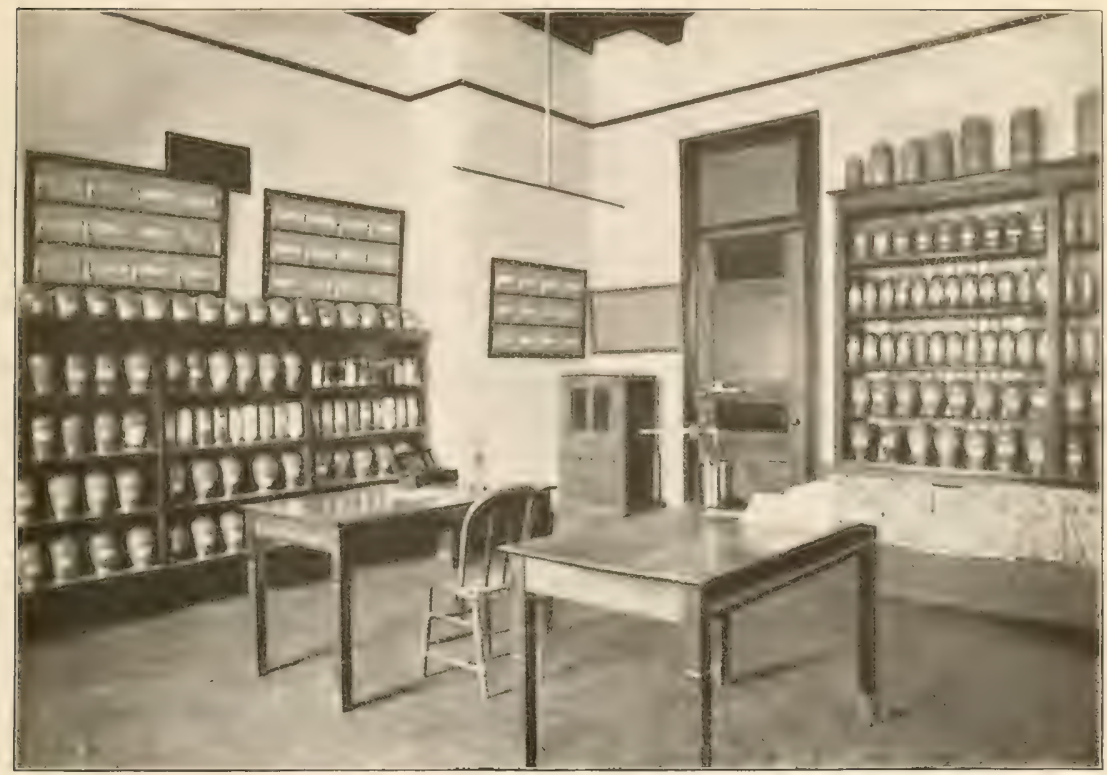

Fig. 1.-University of Nebraska-SeEd Laboratory.

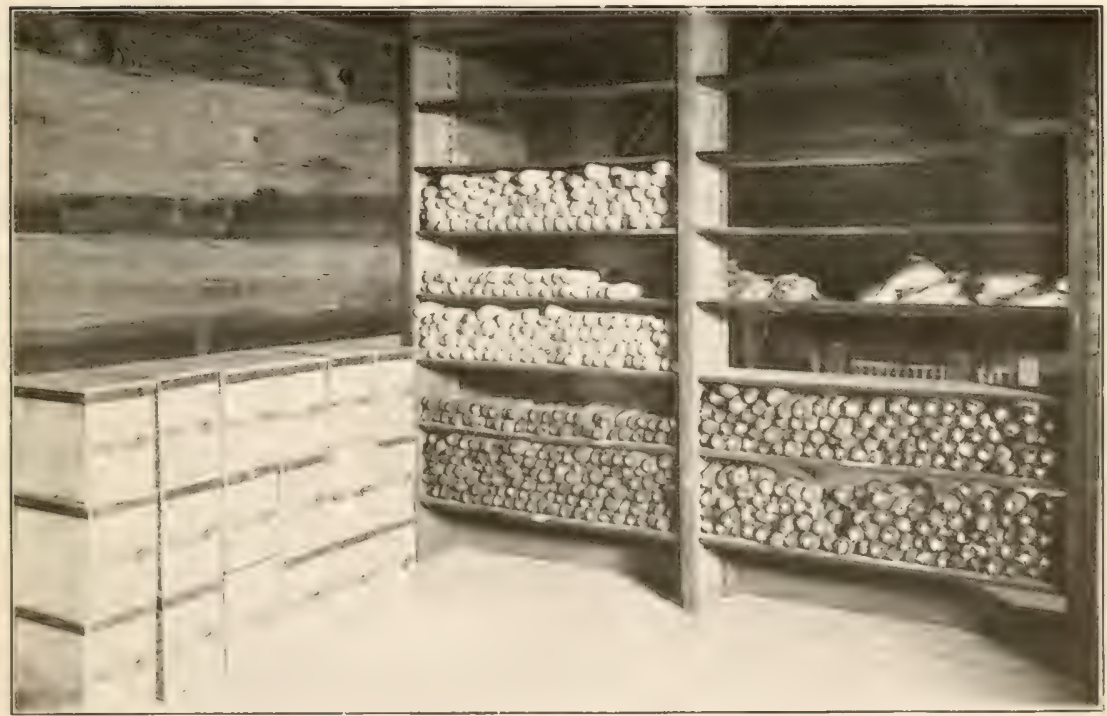

Fig. 2.-Un'versity of Nebraska-Corner in the Seed Storeroom. 

Elective courses are offered as follows:

-. Wrethords of inve-tigation with soils. I study in detail of reported experiments, the object being to familiarize the student with the methods of scientific investigation in the subject under discussion.

"Methods of investigation with field erops. Conducted similarly to the above.

"Plant food in the soil; a series of pot experiments.

"Production and movement of crops as aflecting prices.

"Sugar-beet eulture. History of the culture of the sugar beet. Effect upon general agriculture of sugar-beet culture. Varieties of the sugar beet. Types. Composition and structure of the beet plant. Soils and climatio conditions adapted to raising sugal beets. Preparation of the soil. Planting the seed. Cultivation. Harvesting. Siloing. Seed production; breeding, establishing of strain. Position of the beet crop in the system of crop rotation.

"The laboratory work [in soils] consists of the following demonstrations: Determination of specific gravity of soils; determination of the rolume weight of soils: power of loose soils to retain moisture: the power of compact soils to retain moisture; rate of percolation of water through soils; rate of percolation of air through soils; eftect of mulches on eraporation of water from soils; behavior of the soil toward gases; capillary attraction of the soil; the power of soils to fix ammonia.'

Instruction for students in these courses is by means of lectures and laboratory practice, using books of reference throughout almost the entire course. In thestudy of field crops the experiment station publications are used very freely. Students fitting themselves to be instructors in agricultural subjects or to be experiment station workers are given every opportunity to study the methods of agricultural investigations at the agricultural experiment station farm.

Class rooms and laboratories used for instruction in agronomy are in the general agricultural building(Pl. IX). One class room,33 by 20 feet (Pl. X, fig. 1), contains specimens of plants, seeds, ete., used for purposes of instruction in field crops. One laboratory, 33 by 20 feet (Pl. X, fig. 2 ), is used for demonstrations of rarious properties of soils.

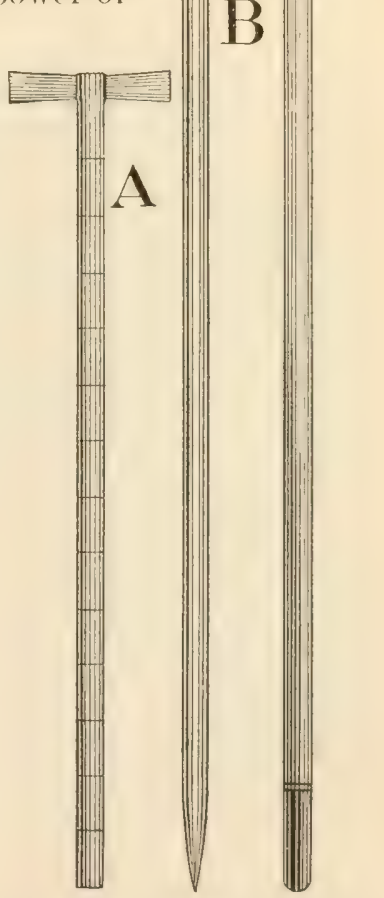

Fir. 8.-Movable soil thermometer: A, hollow steel tube, $\frac{1}{2}$ inch internal diameter, 15 inches long; $B$, solid steel plunger, 19 inches long, which closely tits the tube $\mathrm{A} ; \mathrm{C}$, long stem (18 inches) thermometer which closely tits the tube A. 
This laboratory in provided with desks, water, gas, ote.. and may he

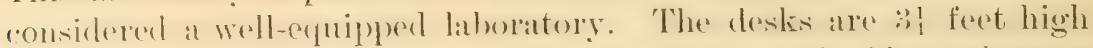
and $t$ feret wide, with drawers and cuphoards on both sides and water and gas cockis in the eronter. The apparatus is designed to record soil temperatures (fig. 8), to take samples of soils (fig. 9), to determine soil moisture (PI. XI, fig. 1), and to test a number of properties of different soils, for instance, the water-holding power of loose and compact soils, the rate of percolation of air through soils, and certain other physical properties, some of the apparatus for which was designed by Professor Gribbs, formerly of the Ohio State University.

Ahout 50 areres of land are used for purposes of instruction, although other land used for experi-

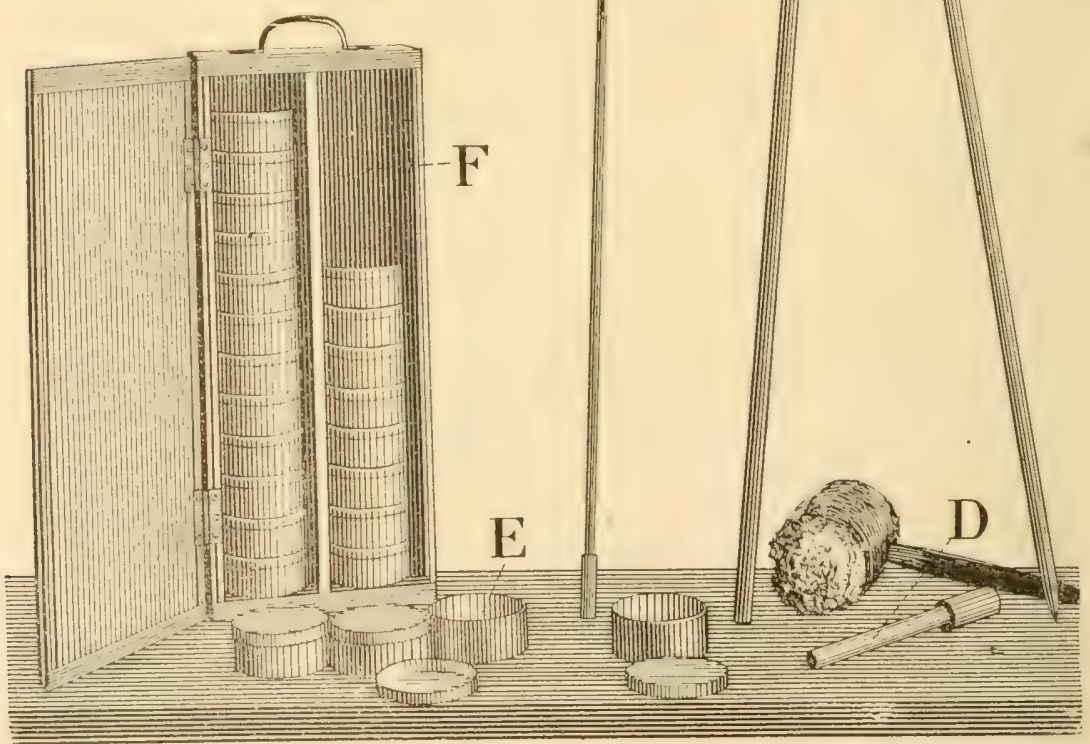

IIG 9-Soil-sampling apparatus: A, hollow stcel sampling tube, $\frac{7}{0}$ inch internal diameter, 45 inches long, marked every 3 inches; 13 , solid steel rod, 46 inches long, which elosely fits $A$; $C$, ejector D, Ariving heud for simpling tube; E, aluminum cans for soil samples; F, case for sample cans.

mentation may alse be eomsidered as a part of the instructional

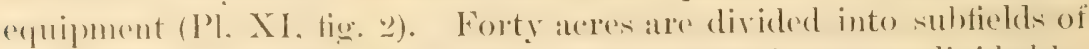

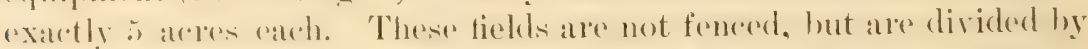
roadways, the land occupied hy which is not a part of the a-acre tracts. 
The roadwatys atre 1 rod wide. Four of the subfields are severally in rotations. intended to demonst rate the eflect of manuring and of perionically sereding tograss. For instance, subfieds ( and 11 atre earch year planted to the same crops and the same chatracter of manure applied in crual guantities, the only diflerence being that at certain intervals - uhbeld II is allowed to lie in grass for a period of years, white subfield $\mathrm{C}$ is cropped continuously. The following is the rotation:

\begin{tabular}{|c|c|c|}
\hline & Subticla C. & Subfield H. \\
\hline $1898 \ldots . . . . . . . .$. & 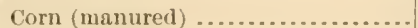 & Bromus inermis. \\
\hline $1899 .$. & Corn & Bromus incrmis. \\
\hline $1900 \ldots$ & Oats $\ldots \ldots \ldots \ldots$ & Bromus inermis. \\
\hline $1901 \ldots \ldots \ldots . . . . . . .$. & 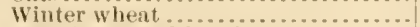 & Bromus inermis. \\
\hline $1902 \ldots \ldots \ldots \ldots$ & Corn (manured in winter) .......... & $\begin{array}{l}\text { Corn (top-dressing of manure before } \\
\text { plowing up Bromus inermis). }\end{array}$ \\
\hline 1003. & Oats ............ & Oats. \\
\hline $1904 \ldots . . . . .$. & 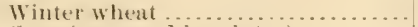 & Winter wheat. \\
\hline $1905 \ldots . . . . . .$. & Corn (manured in winter) .......... & Corn (manured in winter). \\
\hline
\end{tabular}

Subfields I) and I are in similar rotations, except that subfield I) does not receive any manure and that the crops grown on these fields are not the same as those on the other two subfields during the same year. The lemainder of the subfields are used for growing new and not generally grown crops or for particularly good varieties or strains of varieties of common crops. In another field are 10 acres divided into plats of one-fifth are, and each of these is planted to a particular perennial forage plant or combination of such plants. These are mostly grasses and "lovers. They serve as an object lesson in protitable seeding to pastures and meadows in this region. Hurdles of special size are provided for fencing these, so that any one of them maly be pastured when desired. In this manner the pasturage value is demonstrated. There is also a field of about 10 areres divided into experiment plats of one-tenth acre each. These, although primarily for experimentation, are also of value for purposes of instruction.

For instrution in implements and machinery, there are walking, riding, and disk plows; hreaking plows; disk, spike, acme, and springtooth harrows; subsurface packer; roller; subsoilers; prest drills; lister; corn planter; mowers; rake; hay loader; hay tedder; binder; thrashing machine, etc. There are, for instruction in soils, samples of soils from nearly a hundred diflerent localities in the state. These have been analyzed mechanically and the original soil and its constituent parts arranged in small vials on a card showing the percentage of the various sized particles. There is a collection of about an of the native grasises in the state and some zon) specimens of grains (PI. XII, figs. 1 and 2).

The college elasses in soils use suyder's Chemistry of Soils and Fertilizers, but the course is given largely by means of lectures. In field rops frequent use is made of Farmer's Bulletins and state agricultural society reports, and of Morrow and IIunt's Soils and Crops of 
the Farm. The principal books of reference for classes in soils are Le C'onte's Elements of Creology, Warington's Chemical and Physical Properties of Soils, Wahnsehaffe's Scoientific Examination of Soils, Johnson's How Grops Feed. Storer"s Agriculture, and Robertsis Fertility of the Land; for elasses in field repos, the pulbleations of the various experiment stations and of the ['nited states Department of Agriculture.

The agricultural library contains completer or nearly complete sets of the Amals of Agriculture, formal of the Royal Agrieultural society of England, Transactions of the Highland and Agrienltural Society of scotland, (Quarterly Jomrnal of Agriculture, Journal of Agriculture, Journal für Landwirtsehaft, ('entralblatt für Agriculturchemie, Forschungen auf dem (rebiete der Agricultur-Physik, an almost complete set of the publications of the varions state experiment stations. and a farly complete set of the publications of the United states Inepartment of Agriculture. There is also a fairly complete collection of text-books and other books dealing with agriculture in a general or special way, hesides files of the more important agricultural newspapers. Altogether, in that section of the library pertaining to agronomy there are upward of 1,500 volumes.

\section{OHIO STATE UNIVERSITY.}

The four-year course in agriaulture leading to the degree of batchelor of science in atgriculture is griven in the colleger of Agriculture and Domestic Scienere of the Ohio state Iniversity. This andese is designed not only to make specially trained agrieulturists, but also educated men. The course prenplupeses that a young man has had a high school training or its copuivalent, and that he has had the training in farm matteres that necessarily comes to a young man who has lived on at farm. It supplements this training. Init does not displace it. About one-third of the time of the student during the four years is or may be deroted to language (English or foreign), history, and ceonomies: about one-third to pure science, and one-third to technical or professional training. Electives in the senior year allow for some variation in this regard.

Applieants for admission to this course must he at least 16 years of age and have graduated at a State normal school, or approved high or preparatory school, or have passed examinations in the following subjects: English grammar, composition and rhetorice, English "lassies; arithmetic, algehra, plane geometry; deseriptive and physical geography, elementary hotany, and physics: divil government or general history; and Latin (grammar and four hooks of Carior), or French (grammar and simple reading and translating), or (reman (grammar and reading, not less than 300 pages).

The course in agronomy is given during the third or junior year of 


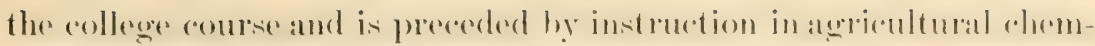

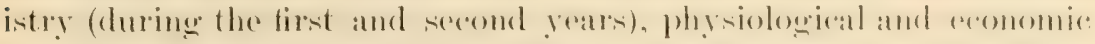
betany and regetahle pathologe (during the liret geatr) and horticulture (during the second year).

In ehemistry the course includes leedures and lalwolatory work on the principles of ehemistry and rhemical momenelatture, oreanice chemeistry, and the applieation of ehemistry to agerenture. The latter is grivenduring the third term of the first year and ineludes the follewing topies: Ingredients of plants. organie and inorganic, essential and nomessential: sourees of plant food, air', and soil; nature of soil, medhanieal portion, nutritive portion, assimilable, and peserve plant food:

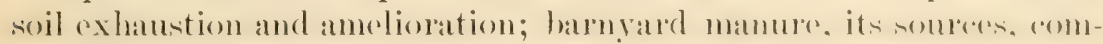
position, and preservation; commereial fertilizers, their rational nse and methods of determining the meeds of soils. In the serond year there are lectures and laboratory work on the industries related to agrieulture (e.g., manulacture of sugar, starch, vinegare, and licpors): and the analysis of fertilizers, feeding stuffis, dairy products, sugar and sugar producing plants, fruits and vegetalsles. water. soils, oils, fats, grains, ete. The lecture rooms and laboratories are thoroughly equipped with alpuaratus and chemicals for the use of instructors and students.

The course in botany includes elementary, physiological, and economic hotany, and regetahle pathology, with lectures and reecitations three times a week and laboratory and field work twier a week. In economic botany the student recesires instruetion and practice in handling the microseope and has the opportunity of learning moth of the important modern methods in technique. The main part of the course in regetable pathology is cleroted to a sturly of the parasitic. fungi most destruetive to enltivated plants, and the means of their prevention forms the last part of the course. Instruction in botany is given in the botanieal building which contains a large lecture room, museum, herlarium, three laboratory rooms, dark room, drying room, storeroom, and offices. The lecture room will, the eoming reatr, contain a stereopticon furnished with electric light: a large number of charts, many of them colored lithographic photographs and mounted illustrative specimens are the principal appliances for daily class work. In this room are placed fifteen of the more important popular journals of botany for the use of students. The botanical books in the miversity library, a valuable and growing collection, arre latredy ned for reference in connection with the sereral courses. The muscum contains a large amount of illustrative material, the native medicinal plants and the collection of Ohio woods being rery complete. The State herbarium consists of between 12.000$)$ and 15.1001 sherets of (Ohio plants. The general herbarium is about the same size. Profestor' Kellerman's private herbarium of $20,0(0)$ specimens, mostly parasitic 
fungi, is also used by the department. The large laboratory is well equipped with dissecting and compound microseopes; also the usual appliances for doing both elementary and adranced histological work. One of the small laboratories is devoted to experimental work in vegetable physiology and the other to systematic botany. The greenhouse attached to the botanical huilding is an important adjunct to the department. There are four sections containing a total of nearly $3,(000)$ feet of gelasi. It contains a large number of illustrative plants, perhatps 3,onk specimens, representing the principal plant families and belonging to several hundred species. The greenbonse furnishes much fresh material for laboratory use. It is also used as a laboratory to carry on special work when growing plants are used.

The courses in agronomy are given by the professor of agriculture and the instructor in agronomy and include two elementary courses luring the seend and third terms of the junior year and two advanced elective courses during the first and second terms of the senior year. The courses in the order in which they must he taken are as follows:

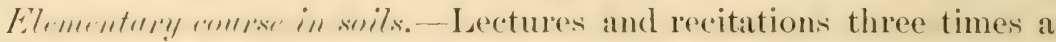
week upon the origin, formation, kinds, and physieal properties of soils and their improrement by eultivation, fertilization, drainage, and irrigation. Practicum once a week in laboratory. testing physical properties of sereral soils: determining the relation of soils to heat, moisture, atr, and fertilizer's, and making mechanical analyses. For a detailed description of the laboratory exereises in this course, see Exhibit No. 7, page 59.

Elementary course in farm crops.-Lectures and recitations three timen a week upon the history, production. marketing, cultivation, and harvestinge of farm erops. For a isat of examination questions indicating the seope of this work, sere Exhibit No. 9, page 70. Pratetictum onere a week with growing and dried specimens of farm aropes,

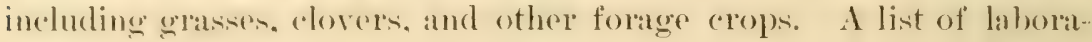
tory or ficld practicums in this course is given in Exhihit No. 10, page 71 .

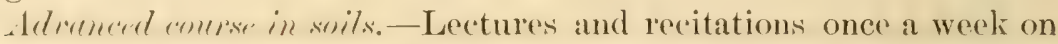
the physical properties of soils; the relation of soils to heat, air, and moisture; the effect of fertilizers on soil structure and fertility: consideration of practical methods of tillage as affecting erop producing power of the soil. Laboratory and field experiments during two twohour periods rach week. A detailed schedule of laboratory work in this course is given in Exhibit No. 8, page 69.

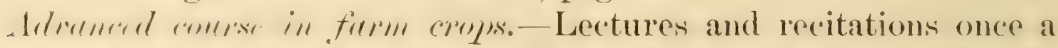
week on (11) the eflect of climate, soil, and markets on the distribution and adaptation of farm crops in the United States; (b) the best method of crop production, including a careful study of the details of field 


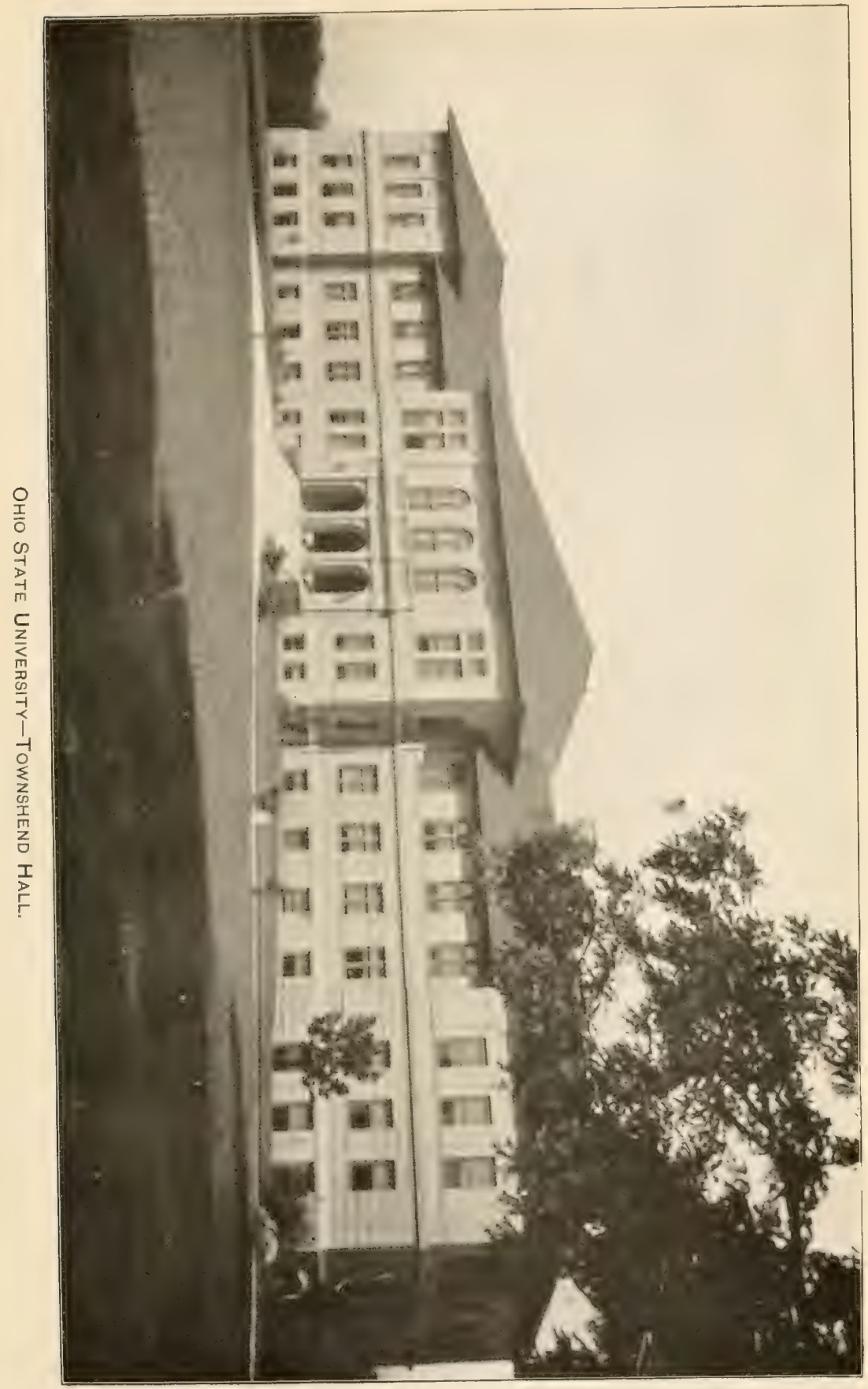



experimentation as set forth in experiment station bulletins and reports and the publications of the Enited states lapratment of Agrienture; (c) the consumption of farm crops. Practicums twire a week.

Instruction in these courses is given lareely by meaths of lectures, hut frequent use is made of such text-books at The Soil and the Physies of Agriculture, by King: and soils and Crops of the Fam, hy Morrow and Hunt: and of bulletins, monographs, and reports issued hy the experiment stations and Departments of the Enited States ( iovermment.

Instruction in agronomy, as in other branches of agriculture, is given in the miversity huilding known as Townshend IIall, which was completed in 1895 at a cost of $\$ 100,000$.

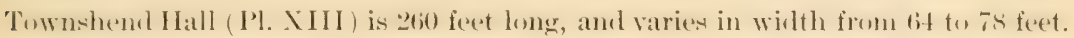
It contains two stories and a basement which is 14 feet high, making the huihling pratetically three stories high. The walls above the hasement line are of gray present brick. The basement walls and the front entrance are of Bedford, Ind., Oolotic limestome, and the trimminger are of terra cotta of the same color as the brick. The roof is of dark-resl tile. The building is of slow-burning anstruction throughout, with painted interior brick walk, exposed beams, maple floors, and hard pine finish. The lecture mons amil lakwatory for the course in agronomy are on the first floor of this building.

The sil physes laboratory is supplied with apparatus for studying the specific gravity of soilw; volume weight of soils; power of lonese soil to retain muisture; perter of complact soil to retain moisture; rate of flow of air through soils; rate of pereolattion of water thromeh soils; effect of mulches on evaporation of water from soils; effeet of eultivation on evaporation of water from soils; power of dry soil to alsorh moirture from the air; and the capillary rise of water through soils. Menhanical analyses are also made of typical soils.

In the study of soils, the large glass house with its equipment of railroad tracks,

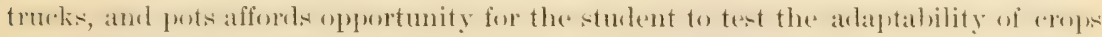
to various soils; the fertilizer requirements of soils and to experiment on varions other problems of crop growth.

In the study of crops, large use is made of the collection of dried specimens of

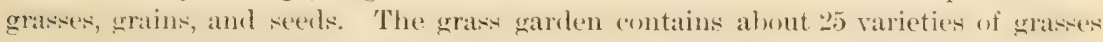
amb rovers growing side by side where comparisons may be mate as to the value of earh for pasture, meadow, and grass. The farm is risited frecunently hy studentis who make olservations and studies of the practical methods there employed in the growing of crops.

Ехнівіт No. 7.

\section{LABORATORY WORK IN THE ELEMENTARY COURSE IN SOILS.}

Experiments are arranged with reference to the number of lahoratory periods in the term, and since there are ten to twelve periods, 12 experiments have been planned which are described on the following pages. The experiments are designed with special reference to the practical demonstration of some of the important principles underlying soil physics, and to supplement clasis-room teaching with actual work with the soil itself.

The following soils used in the experiments are typical agricultura! 
soils seleceted on the Ohio State Lniversity farm with referenes to their differences in texture and crop produeing power:

No. 1. Muck soil. Selected from a very fertile cornfield.

No. 2. First bottom alluvial loam. Very fertile.

No. 3. Second hottom sandy loam with considerable clay.

No. 4. Fine sand (0.25 millimeter to 0.1 millimeter in diameter).

No. 5. Coarse sand $(0.5$ millimeter to 0.25 millimeter in diameter).

The woils are bremght frem the fields and a ir-dried in the laboratery. Numbers 1 to: are sifted through a 2 -millimeter sieve having circular holes, and numbers $t$ and 5 through finer sieves. The soils are then placed in numbered bins in the laboratory.

The following is a list of the laberatory experinents with descriptions and illustrations of each:

\section{Experiument No. 1 .}

DETERIIXATHON OF SPECIFIC GRIVIT OF KOILS.

This experiment shows weights of the various soils as eompared with the weights of equal volumes of water. The specifie gravity of most soils is about 2.5-that is, soil calculated free of air space weighs 2.5 times as much as an equal volume of

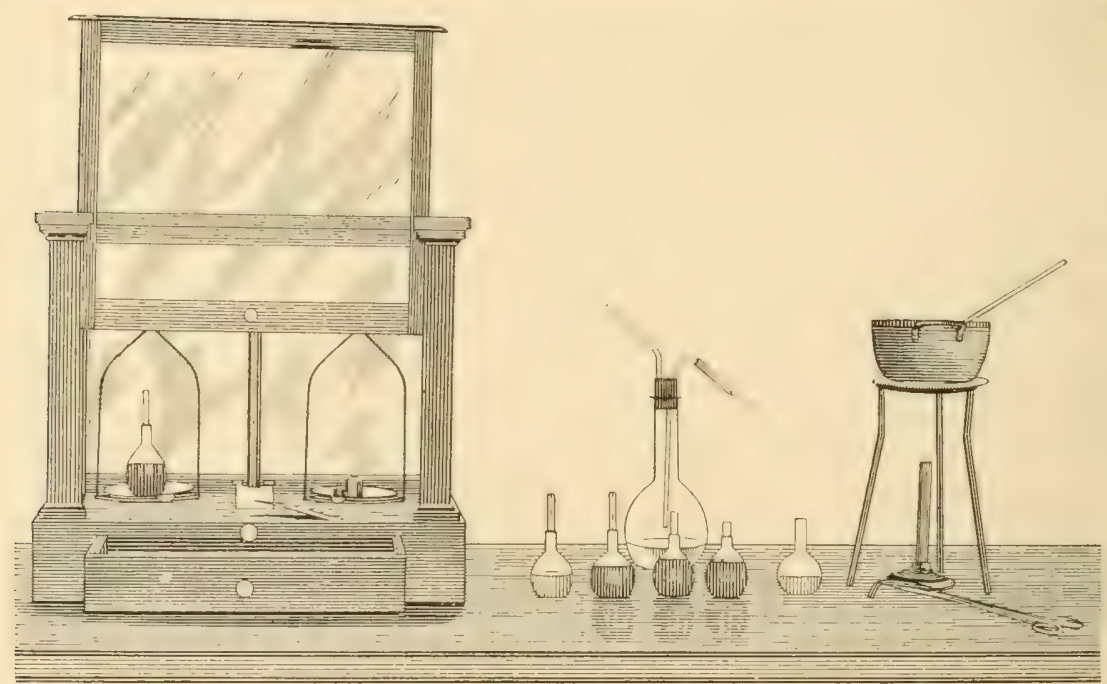

FIG. 10.-A pparatus for determining specific gravity of soils.

water. The more organic matter a soil contains the less its specific gravity. In general, the specific gravity of a soil decreases inversely as its content of organic matter. Specific gravity must not be confused with apparent specific gravity, which will be explained in experiment No. 2.

With a flask of 50 cubic centimeters capacity and provided with a ground-glass stopper, drawn out to an open capillary tube (fig. 10), determine specific gravity of four soils which will be provided-Nos. $1,2,3$, and 4 .

Fill flask with distilled water so that no air bubbles appear after the ground-glass stopper is inserted. Note temperature of water in flask. Wipe flask dry and weigh. 
Pour out about one-half of the water in the flask and put in a weighed quantity (10 grams) of the soil, which has been previously dried at $110^{\circ} \mathrm{C}$. for twenty-four hours. Place the flask in a shallow water bath and boil for two minutes in order to drive out the soil air. Fill the flask with distilled water and bring to the same temperature at which the previous weight was taken. Weigh. (See that flask is full when weight is taken.)

Calculatiom. - Add weight of soil used to weight of flisk filled with water and deduct therefroni weight of llask filled with water and soil. The difference expresses the weight of a volume of water equal to the quantity of soil used.

The specific gravity is found by dividing the weight of the soil taken hy the weight of the water it has displaced.

$$
\text { Experiment No. ¿. }
$$

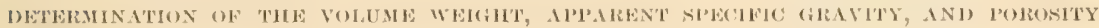

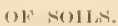

Determine the volume weight of four soils, Nos. 1, 2, 3, and 4 . Weigh the empty tubes (fig. 11) carefully. Use the soil direct from the bins and pour into the tube the measure level full. Then place the tube in the compacting machine (fig. 12) and

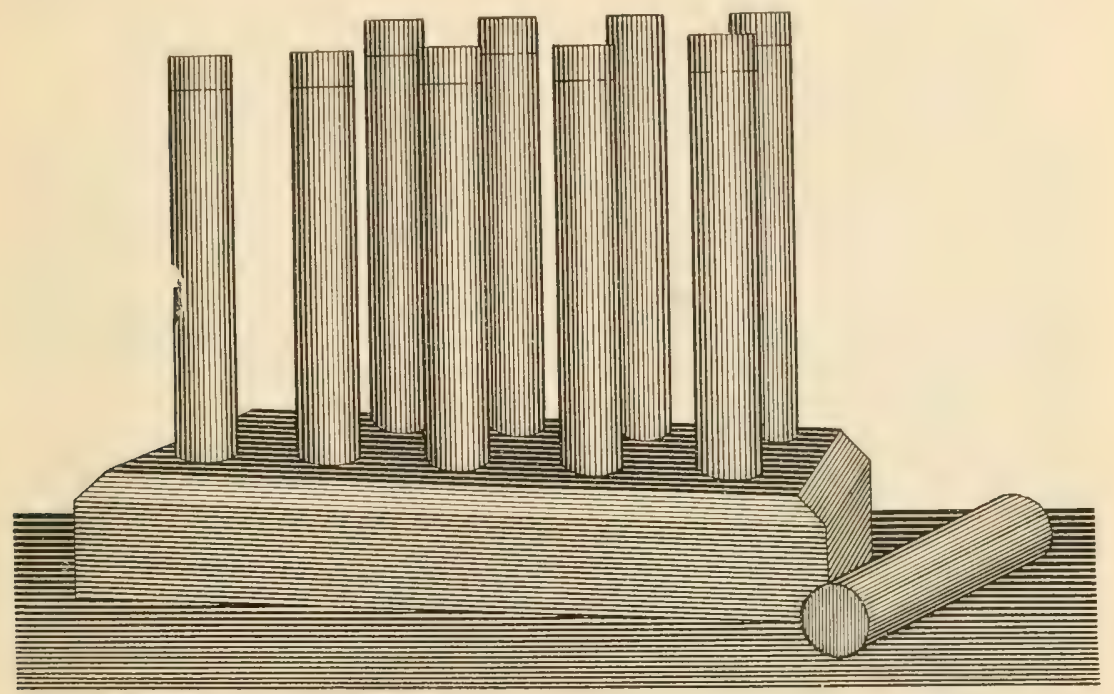

FIG. 11.-Determination of volume weight, apparent specific gravity, and porosity of soils.

allow the weight to fall six times from the 12-inch mark. Pour in another measure of soil and repeat. Continue this until the tube is filled to the mark near the top. Weigh. Determine at the same time with a special sample the hygroscopic water which escapes at $110^{\circ} \mathrm{C}$. Also determine the number of cubic inches, or centimeters, occupied by the soil in each tube.

Calculations. - Subtract the weight of the empty tube plus the weight of hygroscopic water in the soil used from the weight of the filler tube. This will be the weight of the given volume of soil. The volume weight of a cubic centimeter of soil should then be calculated.

By dividing the volume weight of the soil with the weight of the same volume of water, the apparent specific gravity of the soil is obtained.

By dividing this apparent specific enraty with the real speceite gravity of the soil obtained in experiment No. 1, and substracting from 100, the remainder expreseses 
the per cent of porosity of the soil, i. e., the space which, in the dry soil, is occupied by air.

The volume weight of a soil varies with the amount of packing. A freshly plowed soil is much lighter per cubic font than the same soil packed by rains or hy tramping. In other work, will has an apparent and a real specific gratity. Average field soils in good tilth have an apparent specific gravity of about 1.2, and when entirely free from air, a real specific gravity of about 2.5 .

The compacting machine referred to above was designed to pack all the soils into the tubes uniformly and thus eliminate, in a large degree, the error due to unequal packing in different tubes when making comparisons of apparent specific gravity of different soils. The machine does not do the work with aksolute exactness, but seems to be a decided improvement over the uncertain method of filling by hand, which at best gives very unsatisfactory results.

\section{Experiment No. S.}

'IIE PUIFE OF IOOSE SOIIS' TU REIAIN MOISTUIR:

Use soils Nos. 2, 3, 4, and 5 in this experiment. Place disks of damp cheese cloth in the bottom of the tubes (fig. 13) and then weinh the tulnes arefully on the torsion halane. Fill the tuber me to the mark, 1 inch from the tole, ly jouring the soil in gently, leaving the soil in the tubes in a very loose condition, with much air space throughout the mass. Weigh the filled tubes. Place the filled tubes in the empty galvanized iron box. Pour water in the box until the water level almost reaches the tops of the tubes, thus allowing the water to percolate up through the soils. When the water level in the tubes comes up to the level of the water in the box remove the tubes and place them in the frame, where the water is allowed to percolate out of thein. Glass plates should be placed over the tops of the tubes to prevent evaporation. The tubes should be weighed from day to day until the minimum weight is reached-until percolation ceases.

FIG. 12.-Soil-compacting machine.

The difference in weight between the tulese filled with dry soil and the wet soil will be the amount of water retained by the loose soil. In order to get the total water ('ontent of the wet soil, it is necessary to add to this the weight of hygroseopic: water which the dry soil contained. The hygroscopic water of the dry soil should be determined with a special sample taken at the time the tubes are filled. 


\section{(ii)}

Calculate the total number of pounds of water retained jer eubic font of dry soil and also the number of surface inches of water it represents.

This experiment illustrates the power of different types of loose soil to retain water. One of the advantages of cultivating soil is to make it loose in structure so that rain will be absorbed and retained more thoroughly than would be the ease if the soil were uncultivated. Study results from this experiment in connection with those of experiment No. 4 for compat soil.

\section{Experiment No.\%.}

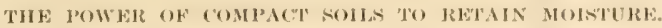

The soils Nos. 2, 3, 4, and 5 in this experiment. Place disks of moint cheese eloth in the bottom of the tubes (fig. 13). Weigh and then fill within 1 inch of the top in the following manmer: Pour in 1 measure of soil. Place cylinder in compacting machine and drop weight six times from the 12-inch mark. Pour in another measure and repeat. Continue this until cylinder is filled within 1 inch of the top.

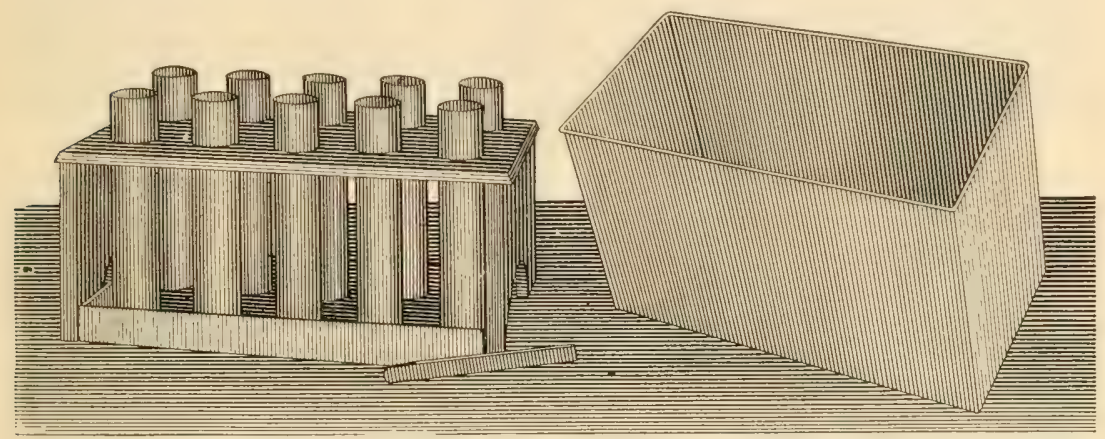

Frg. 13,-Determining the power of soils to retain moisture.

Place the filled tubes in the empty galvanized iron box. Pour water in the box until the water level almost reaches the tops of the tubes, thus allowing the water to percolate up through the soils. When the water level in the tubes comes up to the level of the water in the box remove the tubes and place them in the frante where the water is allowed to percolate out of them. (Glass plates should be placed over the tops of the tubes to prevent evaporation. The tubes should be weigher from day to day until the minimum weight is reached-until percolation ceases.

The difference in weight between the tubes filled with dry soil and the wee wil will be the amount of water retained ly the compact soil. In order to get the total water content of the wet soil it will be necessary to aded to this the weight of hygresente water which the dry soil contained. The hygrosenpic water of the dry soil should be determined with a special sample at the time the tubes are filled.

calculate the total number of pounds of water retained per enbic: foct of iry wil and also the number of surface inches of water it represents.

This experiment illustrates the jower of different types of compant soil to retain water.

The results of this experiment should be studied in rommection with those of experiment No. 3 . 
RATE OF PBITOLATION OF WATER THROUTH SOILS.

The series of tahese (fig. 14) having hesen fillerl within 1 inch of the overfow pipes with soils Nos. 1, 2, 3, 4, and 5, the compacting machine is used.

After each measure of soil was put in the weight is dropped twice from the 6-inch mark. The surface of the soil in each tube is covered with $1 \mathrm{inch}$ of coarse gravel to prevent the soil being disturbed by flowing water.

See that all tubes are connected by rubber tubing and the extreme ends of small tulyes corkert.

Pour in distilled water gently and keep the cylinders almost level full. After the flow into the glass flasks has become uniform, note the number of cubic centimeters which flow through in half an hour. Determine this by measuring in a graduated revlinder.

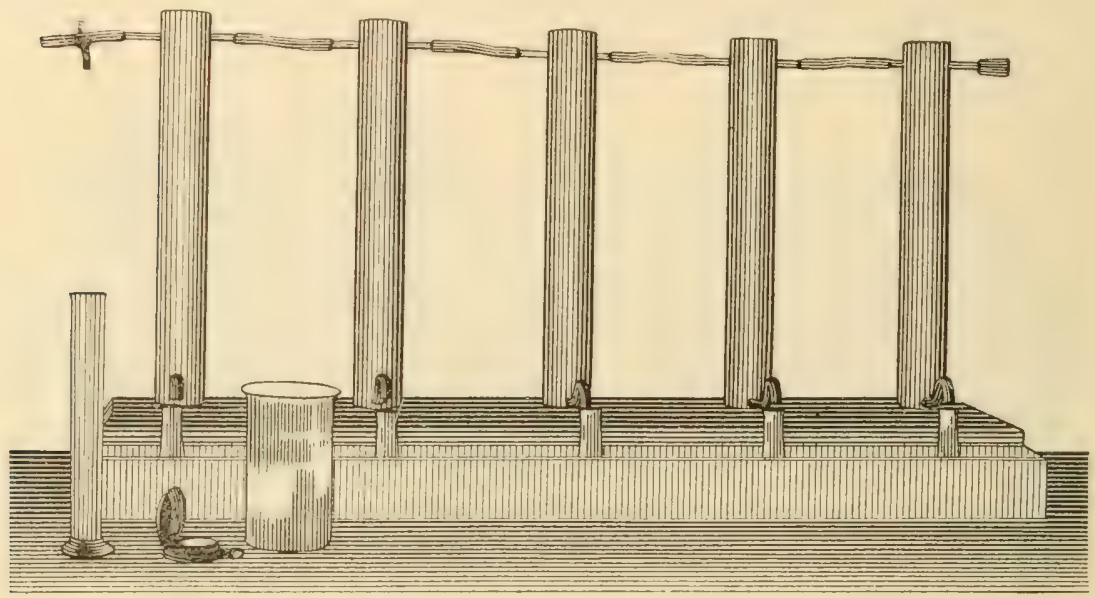

Fig. 14.- Rate of pereolation of water through soils.

The character of soils used may be examined in the boxes in the laboratory. 'The tubes are numbered to correspond with the soil numbers.

This experiment brings out the differences between soils in regard to the rate of percolation of water through them. Other things equal, it is desirable that a soil should allow water to pass through slowly, holding moisture the greatest length of time within the reach of erop roots.

Experiment No. 6 .

RITE OF FLOW OF AR THROUGHE NOHIS.

Soils Nos. 1, 2, 3, 4, and 5 are used in this experiment. The cylinder numbers correspond with the soil numbers.

The compacting machine was used in filling the cylinders (fig. 15). After each measure of soil, the weight was dropped three times from the 12-inch mark.

Open the cock on the copper cylinder and detach the hook holding the weights. Allow the copper cylinder to sink by its own weight. Attach the rubber tube to soil tube No. 1. Attach the weight hook and note the number of degrees passed by the pointer in 10 minutes or a longer time, if it be necessary in case of the finegrained soils. Recorrt the weinht fur each of the five soils, calculating the weight per homr. 
This experiment has a clirect practical hearing on the guestion of soil ventilation. Seril air is essential te the life of nitrifying and enher hacteria whe helecelep fertility. Other things, equal, the nore readily soil will allow air to circulate through it, the more farorable conditions will be for the formation of plant food.

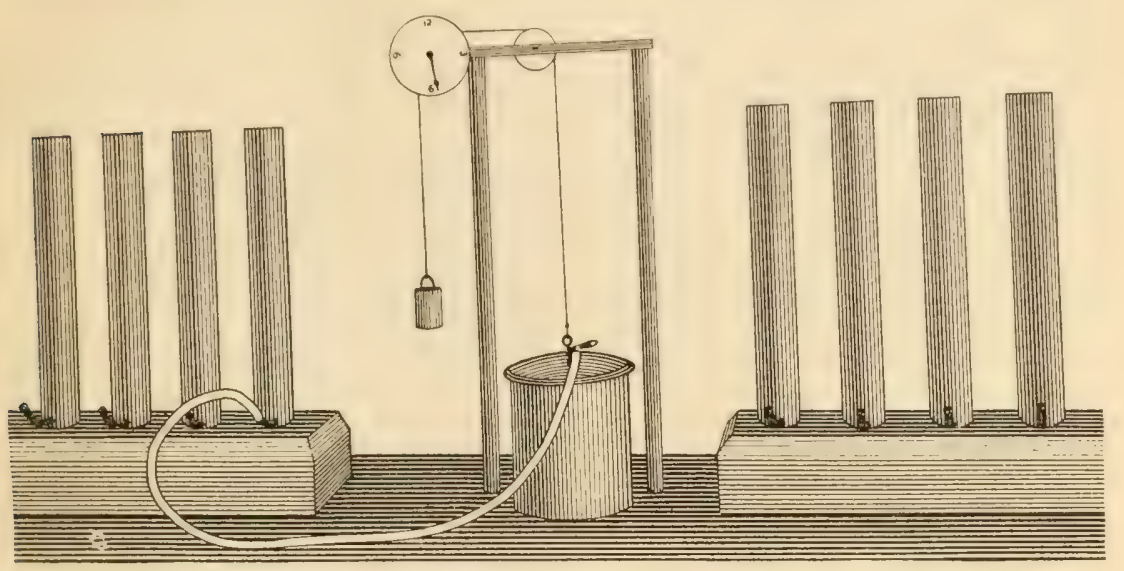

- Fig. 15.-Apparatus to determine the rate of How of air through soils.

Experiment $N_{0 .} \%$

EFFECT OF MUICHES OX EVAPORATION OF WATER FROM NOILS.

The cylinders (fig. 16) are 18 inches deep by $t$ inches in diameter, and are filled with first bottom soil from the Ohio State University farm. The compacting

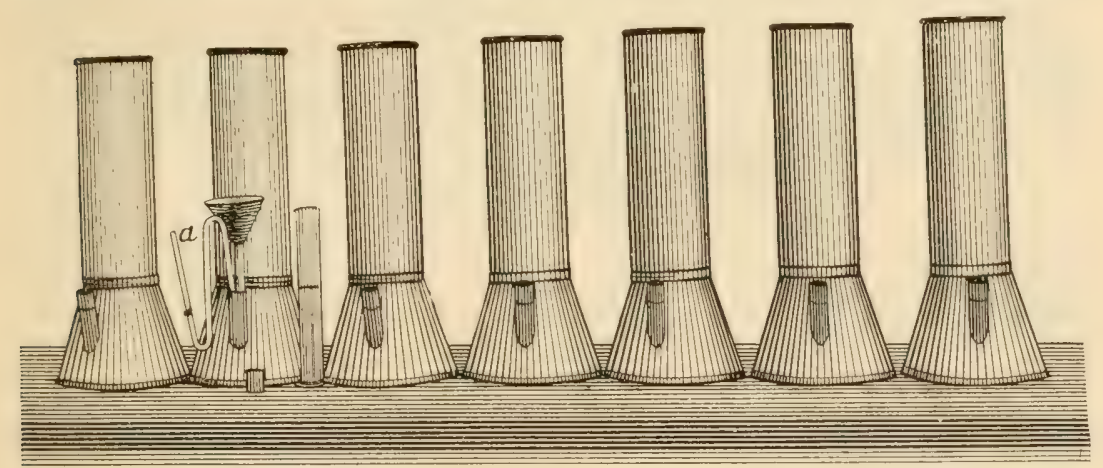

Fig. 16.-Soil tubes for showing the effect of mulches on evaporation of water from soils.

machine was used in filling the cylinders to insure comparatively uniform compactness of soil in all eylinders.

No. 1. Not mulched.

No. 2. Not mulched.

No. 3. Surface cultivated 2 inches deep. (Soil mulch).

No. 4. Surface cultivated 2 inches deep. (Soil mulch).

No. 5. Mulched with 2 inches of coarse gravel.

No. 6. Mulched with 2 inches of fine sand.

No. 7. Mulched with 2 inches of sawdust.

No. s. Mulched with 2 inches of eut straw.

$267-7-N o .127-03--5$ 
No. 9. Not mulched. (Placed in draft).

No. 10. Not mulched. (Placed in draft).

Fill the cylinders to the same level with distilled water every twenty-four hours for one week and keep a careful record of the amount of water used each day. The "S" glass tube ( $a$, fig. 16) will be used to cletermine the exact level to which the tubes should be filled.

The cylinder which evaporated the least water during the period of observation should be the one haring the most effective mulch.

In recording results show the amount of water put in each cylinder daily, and also the total amount for each cylinder for the entire run of the experiment.

\section{Experiment Vo. 8 .}

THE IOWER OF IIR-IRY SOIL, TO ABMORL MOISTYIE FRON THE AIR.

L'se soils Nos. 1, 2, 3, and $t$ in this experiment. Place 400 grams of air-dry soil from the bin in a shallow zinc tray (fig. $1 \dot{7}$ ), spreading it out as uniformly as possible.

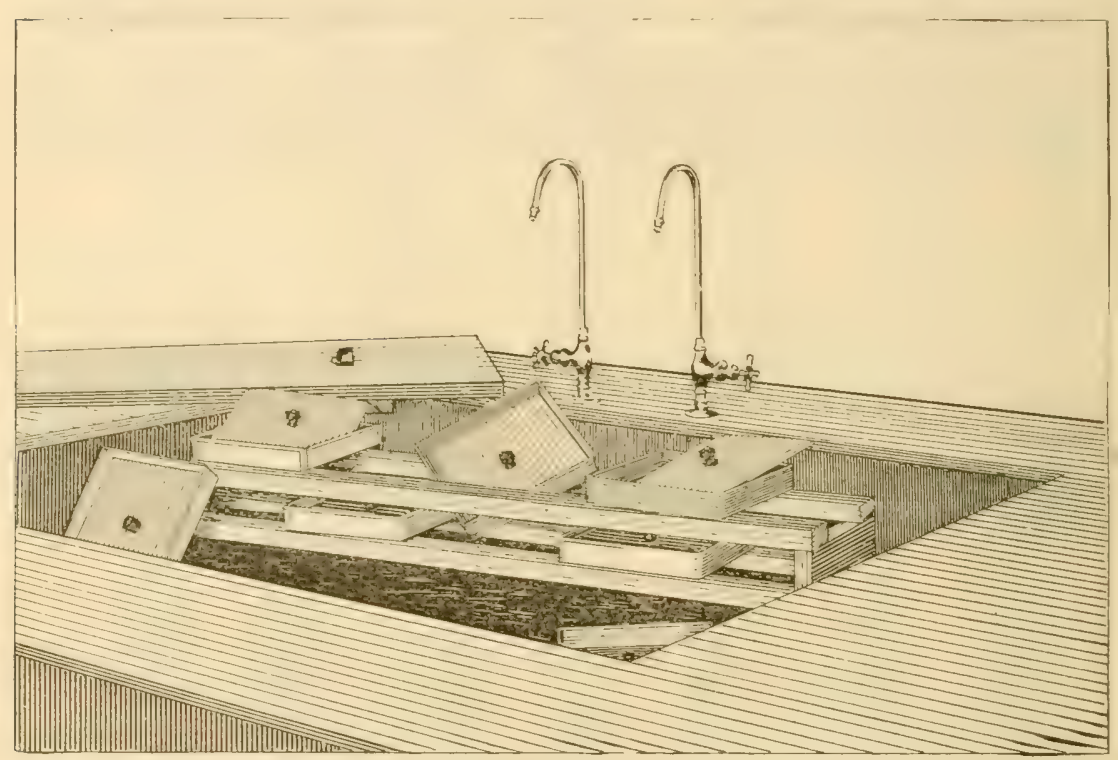

FIG. 17.-Determining the power of air-dry soils to absorb moisture from the air.

After weighing the tray (lid on) with the soil, place an empty weighed box, together with the others (lids off), upon a shelf in the pneunatic trough. Place a thermometer in the trough and at each weighing read the temperature. Weigh each box (lid on ) every twenty-four hours and deduct the increase in weight of the empty box from the increase in weight of each of the other boxes. Repeat the weighings every

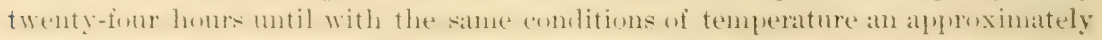

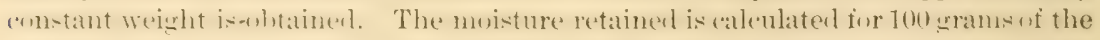
soil dried at $110^{\circ} \mathrm{C}$. Add to this increased weight per 100 grams of air-dry soil the weight of hygroscopic water contained in 100 grams of the air-dry soil. This will give the total amount of water taken from the air by 100 grams of water-free soil.

Determine the hygroscopic moisture of each soil with a special sample at the time of starting the experiment.

This experiment brings out the fact that dry soils absorb only a very small amount of moisture from the air, even when the air is saturated, thus correcting an opinion which is prevalent but erroneous. 
Experiment No.9.

A STEDY OF THE RITE OF IRISE OF CAPLLARY WATER IX SOILS.

Use soils Tos. 1, 2, 3, 4 , and 5 in this experiment. Place a cheese-cloth disk in the hottom of each tube (fig. 18) to prevent the escape of soil grains. Use the com-

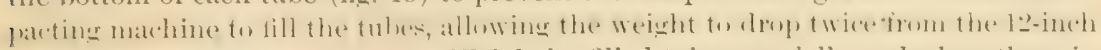
mark after each measure of soil. Weigh the filled tubes carefully and place them in the frame with the lower ends standing in about 1 inch of distilled water, which should be maintained at constant level.

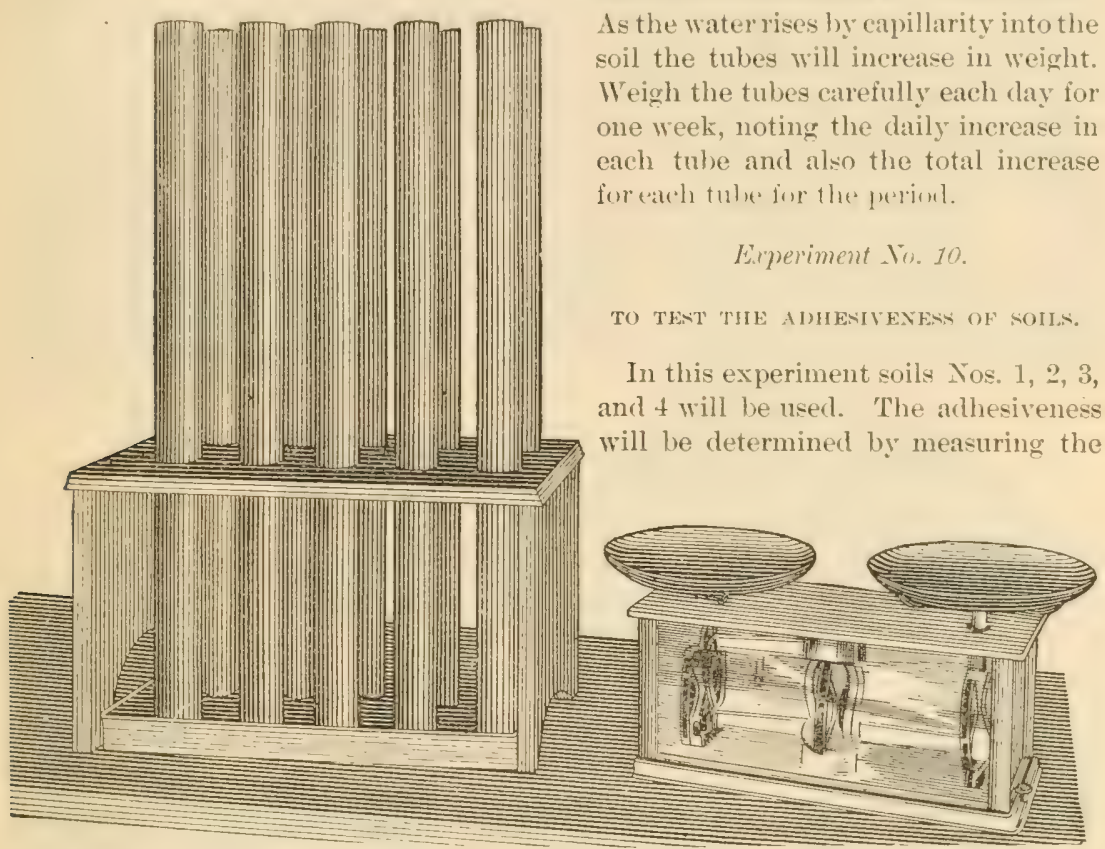

Frg. 18,-Aleasuring capillarity in soils.

force required to orercome the molecular attraction in a column of moist soil 1 square inch in cross section.

Weigh ont roughly 150 grams of soil To. $_{1}$ and 180 grams each of $\mathrm{Nos}, 2,3$, and 4 .

Determine the force refuired to start the empty movable eage (1) ly rumning samel from the rubber tube $(b)$ into the tin pan $(c)$ until the weight is sufficient to cause the cage to move (fig. 19). See to it that the cages are clean and the bearings clean and oiled. The weight of the pan plus the sand it contains represents the force

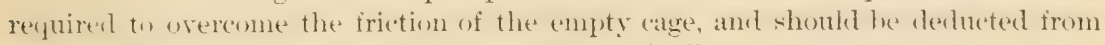
the total breaking force in each subsequent test of soil.

Empty the weighed sample of soil upon the "mixing board" and add a small quantity of water. Mix soil and water thoroughly by hand working. Enough water should be added to bring the soil to its maximum adhesiveness.

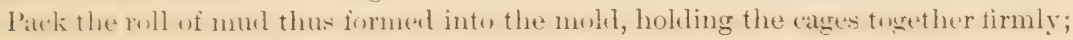
then with the spatula scrape off the top level with the upper edge of the mold. Attach the pan to the hook at the end of the wire. Pour sand into the pan in a comstant stream until the weight is sutticient to separate the cages aum break the soil column. Weigh the gan with the sand it contains and deduet therefrom the weight

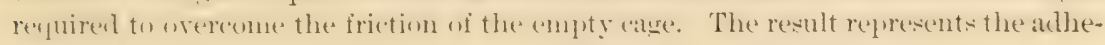
sive strength of a column of moist soil 1 square inch in cross section. 
Care should be exercised to fill the molds as nearly as possible in the same manner in each test.

With this same roll of und make four tests, using varying amounts of water. The fropurtion of water maty be reduced by adding more dry soil. Te t earh of the four types of soil in the above manner, using the highest test of each for comparisons of maximum adhesiveness.

Experiments Nos. 11 and 12.

MECHANICAL ANALTSIN OF NOHLS.

A modification of the method used in the laboratory of the Bureau of Soils of the United States Department of Agriculture. (Pl. XIV, fig. 1.)

Twenty grams of "fine earth" are weighed out and placed in a porcelain or glass mortar. Enough water is added to give the soil the consistency of paste. The mixture is then rubbed with a rubber-tipped pestle.

In rubbing there should be just enough pressure to detach

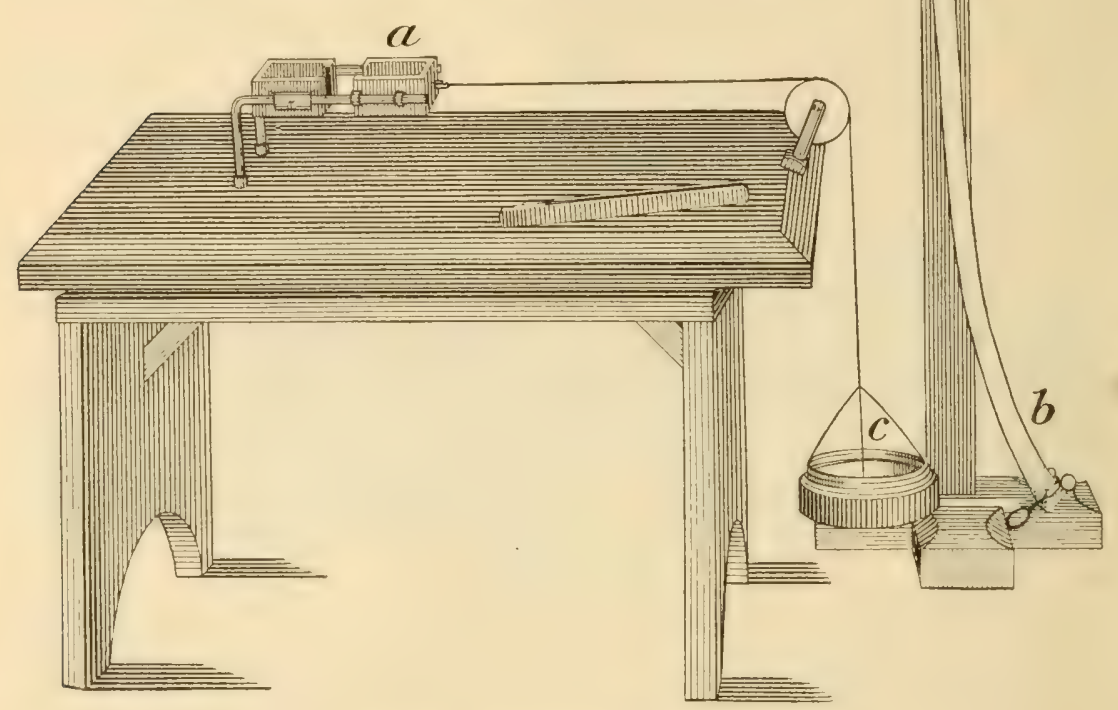

FIG. 19.-Apparatus for testing the adhesiveness of soils.

aithering farticles and not enough to break the grains. Ifter five minutes rubling more water may be added, and after letting it stand for two or three minutes the turhid liquid is decanted into a heaker, "А." Pieperat this pestling and decanting until an examination through the microseope shows the grains to be perfectly clean. When clean the grains show sharp ontlines and are transparent, while any athering finex particles make them round and deeply (w)lored. This pestling naty require 15 minutes to an hour or more.

When the material is thoroughly disintegraterl, it is transferres from the mortar to a No. 2 or No. 3 beaker, which is then filled with water, stirred and allowed to staml a few minutes, atter which it is carefully decanted, leaving the last 20 or 30 cubic centineters, the liquor heing arledel to the ieaker "d." This is repeated until the sand is free from clay, fine silt, and much of the silt. The sand should be tested with the microscones. All particles smailer than 0.05 millimeter are silt or fine silt 


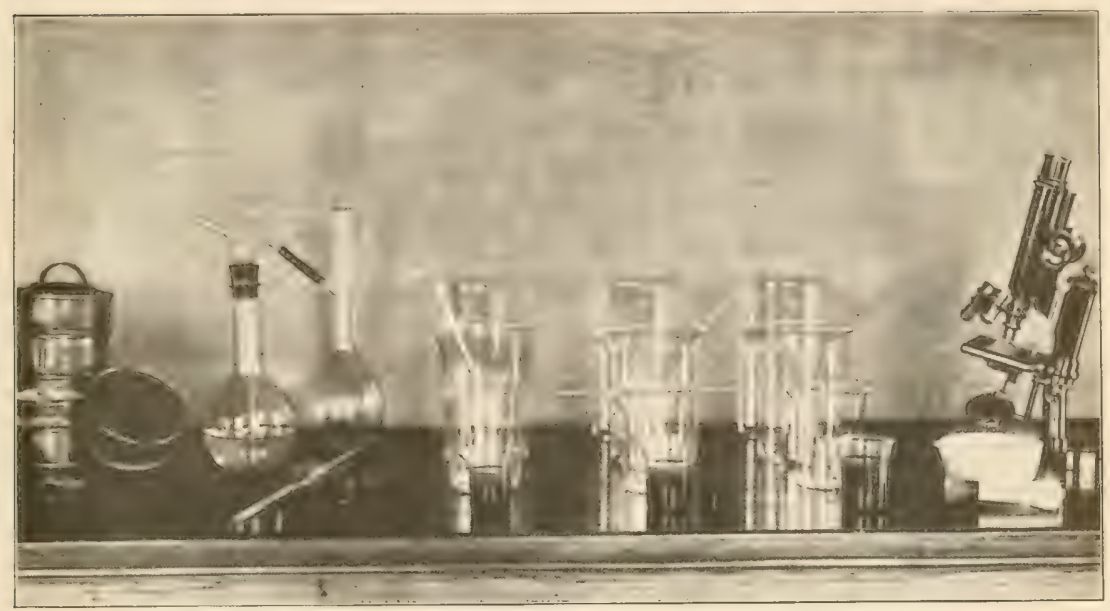

Fig. 1 -Ohio State University-Mechanical ANALYSIS OF SOIL.

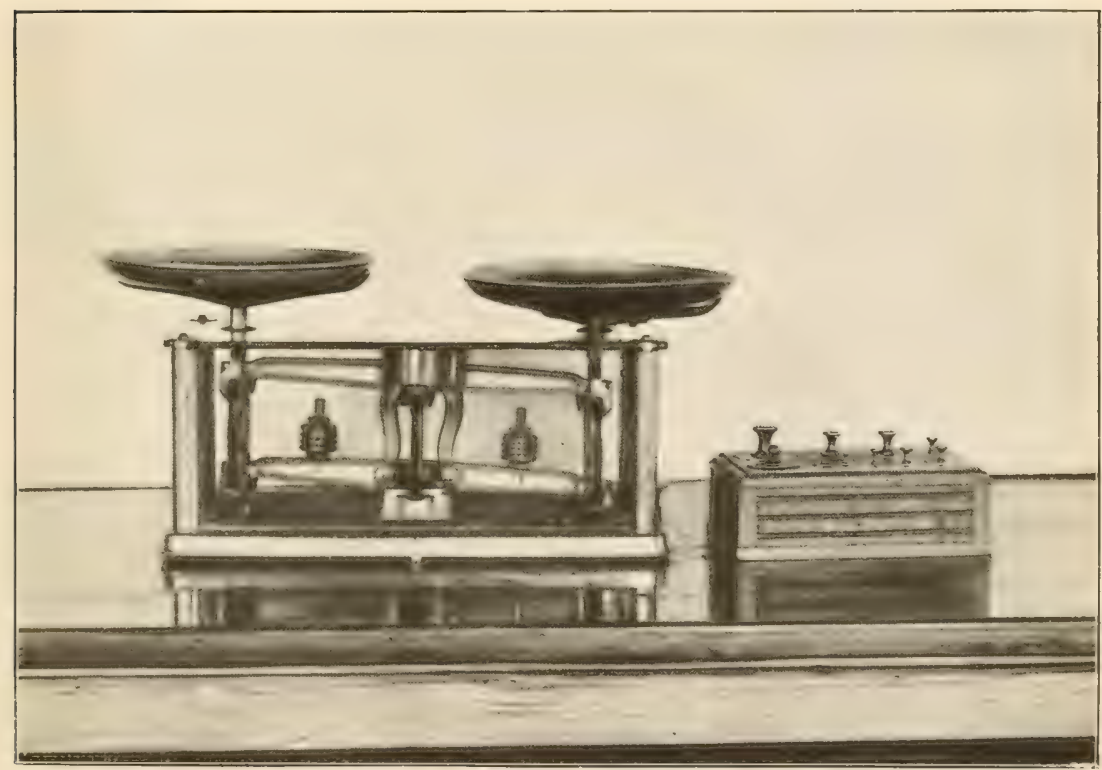

Fig. 2.-Ohio State University-Torsion Balance USEd In SOIL Physics LABORATORY. 

and should be removed by further decantation. The sediment in the bottom of beaker " $A$ " should also be tested. If it contains particles larger than 0.05 millimeter, the washing or decantation was ton rapid. In this case a recovery must be made.

The sand is transierred from the beaker to a porcelain dish and dried. It is then

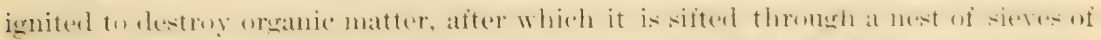

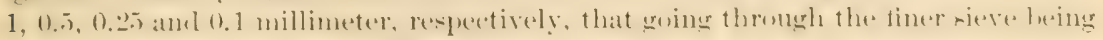
known as very fine sand. These five sejarations are weighed together before the sifting and separately after sifting.

The amount of silt, fine silt, and clay which was washed away from the sand may be obtained approximately by subtracting the total weight of sand, moisture, and organic matter from the earth taken (20 grams).

Considerable time and skill is required to make the separation of silt, fine silt, and clay. It will not be attempted in this experiment.

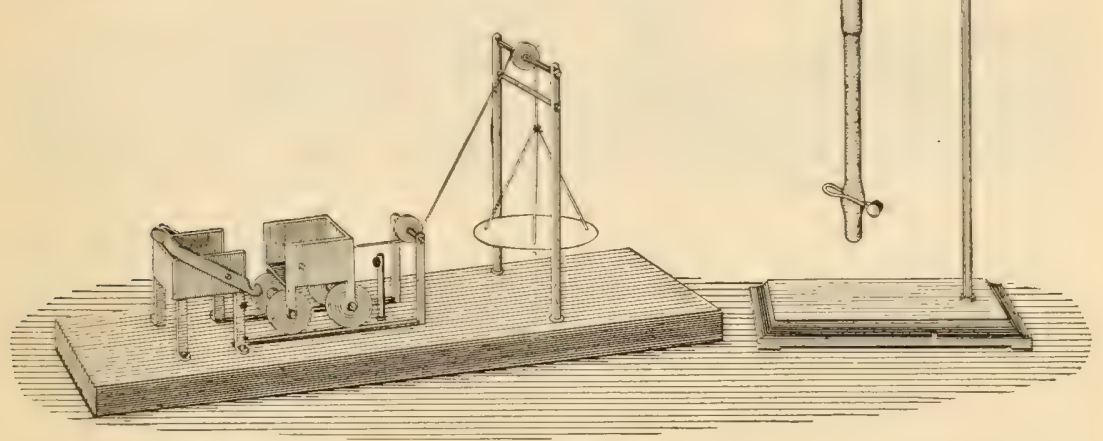

Fig. 20.-Card's apparatus for testing the adhesiveness of soils.

The following are the sizes into which the soil particles are separated:

No. 1. Gravel, 2-1 millimeters.

No. 2. Coarse sand, 1-0.5 millimeter.

No. 3. Medium sand, 0.5-0.25 millimeter.

No. 4. Fine sand, 0.25-0.1 millimeter.

No. 5. Very fine sand, $0.1-0.05$ millimeter.

No. 6. Silt, 0.05 -0.01 millimeter.

No. 7. Fine silt, 0.01-0.005 millimeter.

To. S. Clay, 0.005-0.0001 millimeter.

Students are requiresl to keep a careful record of each experiment, and at the end of the term to present plates showing their results, and also illustrations of apparatus used, together with description of the method employed.

\section{Exuibit No. 8.}

\section{DETAILED SCHEDULE OF LABORATORY WORK.}

\section{Adranced course in soils.}

September 15 and 19.-Collected samples of soil from fallow, alfalia, and corn ground to determine moisture content of first and second foot, nsing sampling tules and other apparatus, as illustrated in fig. 21. 
September 25 and 26.-Collected samples of surface foot of muck, first bottom and second botom soil, for determination of weight per cubic foot of soil under field conditions, using large tube, as illustrated in fig. 21.

October 2 and 3.-Discussion of results as obtained in the above experiments with special reference to the methols of expressing amounts of water in the soil; that is, per cent fresh weight, per cent dry weight, amount of water per cubic foot, and surface inches water.

October $9,10,16,17,23,24,80$, and 31.- Mechanical analysis of two samples of soila sand and a clay-by the Osbome beaker method, as modified and used by the Bureau of Soils and described in Bulletin To. 4 of the Bureau, pages 8-13.

Norember 6, \%, 13, and 14.-Separation of "silt," "fine silt," and "clay" by the centrifugal method as used in the Bureau of Soils.

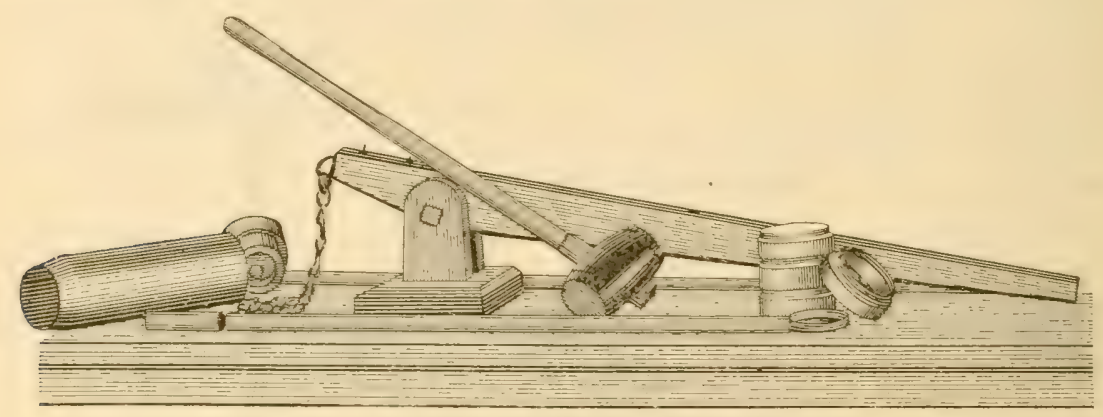

Frg. 21.-Apparatus for taking soil samples.

Yorember $20,21,2 \%, 28$, end December $4,5,11$, and 12.-Detemination of moisture, soluble salts, and temperature of soils by the electrical method, as deseribed and used by the Bureau of Soils.

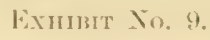

\section{EXAMINATION IN ELEMENTARY COURSE IN FARM CROPS.}

The following list of examination fuestions will serve to inclicate the scope of the work covered in the course:

1. Name and explain the reasons for crop rotation.

2. Explain three methols of crop improvement.

3. Give the following statistics on corn and oats for the Lnited States during the last decade: ( $(\ell)$ Arerage annual acreage; (b) average annual yield; (c) average annual yield per acre; $(d)$ areragre value per acre.

4. Name the eight leading States in the proluction of each of the following crops: Corn, oats, and barley.

5. Describe structure and give chemical composition of a grain of wheat.

6. Name the types of Indian corn and give the distinguishing characteristics of each.

7. Give the chemical composition of corn.

s. Give general directions as to depth of planting, time of planting, and thickness of planting corn.

9. State the reasons for shallow cultivation of corn.

10. Discuss the following: Time of sowing, depth of sowing, and amount of wheat to sow per acre.

11. What points should be considered in distinguishing between varieties of wheat? 12. Discuss briefly the cost and methods of shipping grain from the farms of the Northwest to the Atlantic seaboard.

13. State the conditions of elimate, soil, and seed bed best adapted for oats. 
14. Disenss depth of sowing, time of sowing, and amount of oats to sow per acre.

15. Name the regions of greatest production of rye and barley in the United States.

16. Give briefly the history of the cultivation of grasses and clovers.

17. Give common and scientifie name of six grasse. that are grown in Ohio.

18 and 19. Under the following heads discuss common xed clover, crimson clover, alsike clover, altalfa: ( 6 ) Scientific name; (b) value for pasturage and hay; (c) climate and soil conditions favorable.

20 and 21. Tnder the following heads discuss Indian com as a silage erop: ( 1 ) Total yield of digestible inutrients as compared with other crops; (3) rarieties best adapted; (c) thickness of planting; (d) proper stage of maturity for harvesting.

22. Give directions for growing sugar beets.

Exнивт No, 10,

\section{LIST OF LABORATORY OR FIELD PRACTICUMS IN ELEMENTARY COURSE IN FARM CROPS.}

Praticum No. 1.

Eight varieties of corn are grown on the university farm ammally for instructional purposes. Students are given this work in the fall term of necesity. Each stulent is provided with the accompanying score card and asked to judge only the stalks in this exercise.

Practicum No. 2.

The ears, lunsked from the variety plats, are brought to the laboratory, where a few of the best are selected and the students are asked to seore them carefully, according to the card standards as indicated in the following form:

Students' seore curr.

I)EXT' CORN.

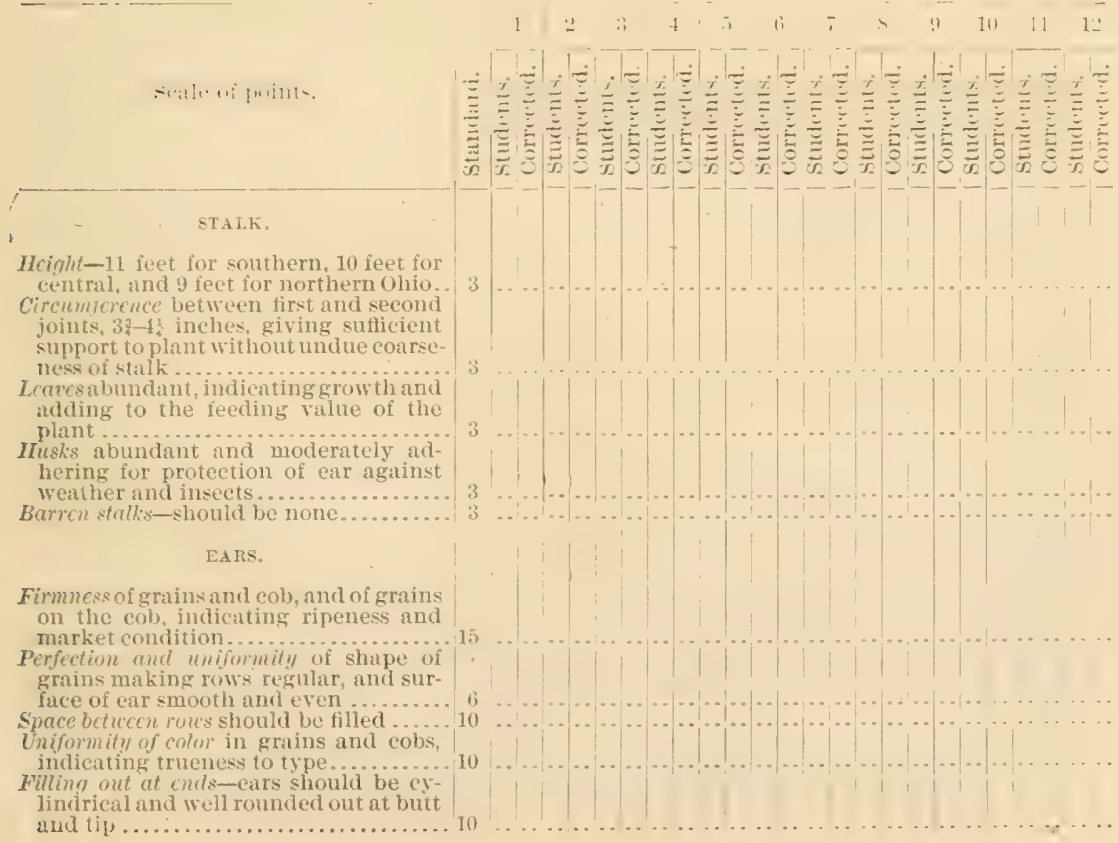


Students' score cerit-Continuerl.

DEXT CORX-Continned.
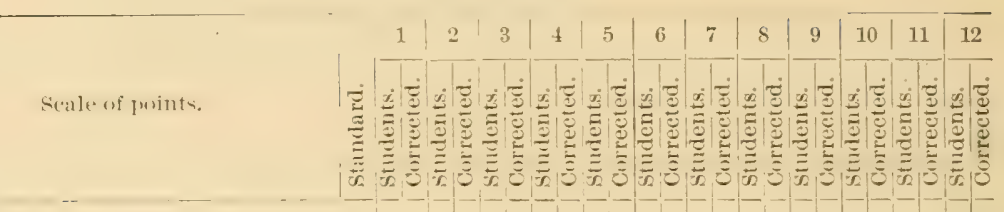

\section{EARS-continued.}

Per cent of grain to car, 85 percent. Estimated, $\frac{}{\text { Lenoth }-10 \text { inches in southern and cen- }}$ tral, and 9 inches in northern Ohio ... 10 Circumference, at two-fifths the length, measuring from base, $7-7 \frac{1}{2}$ inches in southern and central, and $6 \frac{1}{8}-7$ inches in northern Ohio ................. Jincture of cob with stalk, anch in diameter, giving sufticient support for ear without causing inconvenience in breaking

Tortal ...

\section{NAME OF VARIETY.}

1.
3.
4
5.

4.

\section{siluitent:}

I)ate:

\section{Practicum No. 3.}

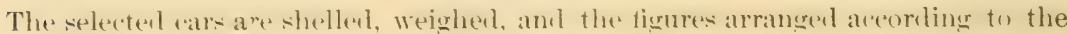
following outline, which is handed them:

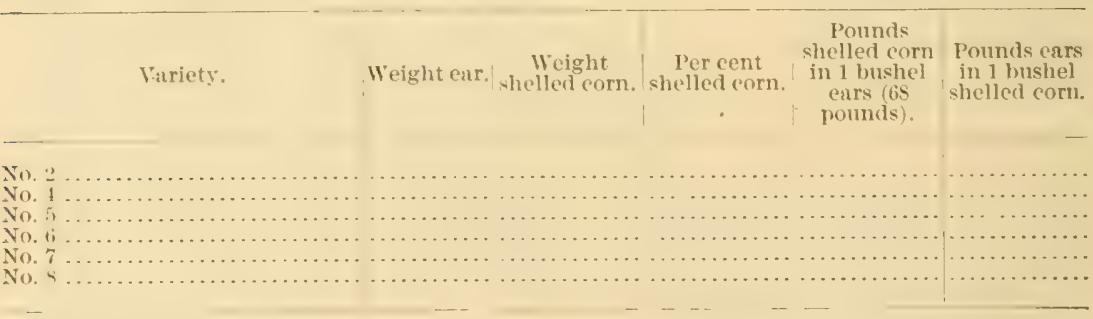

Remarks:

Practicum No. 4 .

A STUDY OF TIIRTY-NINE VARIFTIES OF WINTER WHEAT-CLASSIFICATION.

A. Bearded:

(a) Glumes white.

(a') Berry red.

1. Length of straw less than 3 feet 6 inches.

2. Length of straw more than 3 feet 6 inches.

(b') Berry white.

3. Length of straw less than 3 feet 6 inches.

4. Length of straw more than 3 feet 6 inches. 
A. Bearderl-Continued.

(b) Glumes bronze.

(a') Berry red.

5. Length of straw less than 3 feet 6 inches.

6. Length of straw more than :3 feet 6 inches.

(b'j Berry white.

7. Length of straw less than 3 feet 6 inches.

8. Length of straw more than 3 feet 6 inches.

B. Beardless:

(a) Glumes white.

(a') Berry red.

9. Length of straw less than 3 feet 6 inches.

10. Length of straw more than 3 feet 6 inches.

$\left(b^{\prime}\right)$ Berry white.

11. Length of straw less than 3 feet 6 inches.

12. Length of straw more than 3 feet 6 inches.

(b) Glumes bronze.

(a') Berry red.

13. Length of straw less than 3 feet 6 inches.

14. Length of straw more than 3 feet 6 inches.

(b') Berry white.

15. Length of straw less than 3 feet 6 inches.

16. Length of straw more than 3 feet 6 inches

Each student is required to hand in a written report of this work.

Practicum No. 5 .

Ahout May 1 each year the class spents one period naking motes on the condition of 15 to 20 varieties of graseses amd chovers in the grass garden for now later in the term when they come to study the varieties more fully.

Practicum No. 6.

The "Howe Grain Tester" is used in testing the purity and weight per bushel of wheat, oats, etc.

Practicums Nos. 7, 8, 9, and 10 .

Ahout four periods at the close of the term are given to the stuty of 15 tw 20 varieties of grasses, clovers, and forage plants. Students use the lried specimens in the laboratory as well as the growing phants in the "grass garden." The following untline is griven earh student, who is requirest to present an essay on the subject at the end of the term:

\section{DESCRIPTION OF GRASAEN AND FORAGE PLANTS.}

Describe the following plants from the loundles given and state use, value, and climatic range and adaptation to sull, and give briefly the results obtained with these plants at experiment stations and elsewhere.

The following hooks may be need for reference, while below will be given references under each variety to results at experiment stations:

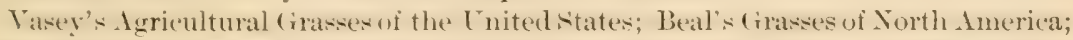
Ilackel's True (irasses; Hamlhook of Experiment Station Work; (irasses of Tennessere, I'art II; Grasses ami Clovers, Field Ronts, Forage and Folder Plants, hy

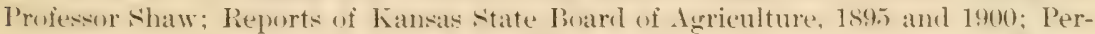
manent amd Temporary lastures, Sutton; Forage Crops other than Grasses, shaw; Bulletins of the Division of Agrostology:

1. Pore motensis, L., hentucky Blue (irass, Bulletins is and 15, Illinois station; Bulletin 20, Mississippi Station. 
2. Agrostis vulgaris, I., Reitop, Bulletin 15, Illinois Station; Bulletin 20, Mississippi Station.

3. Phlewin matense.

t. Llopecurus pratensis, L., Meadow Foxtail.

5. Ductylis glomerate, L., Orchard Grass, Bulletins 5 and 15, Illinois Station; Bulletin 20, Mississippi Station.

6. Frstuca elatior.

7. Fextuca matensis, Huds., Meadow Fescue, Bulletins 5 and 15, Illinois Station.

8. Lolium perenne, L., Perennial Rye Grass, Bulletin 12, Colorado Station; Bulletin 15, Illinois Station; Bulletin 20, Mississippi Station.

9. Avena clutior, L., Tall Mearlow Oat Grass, Bulletin 15, Illinois Station; Annual Report 1889, Mississippi Station.

10. Anthoxenthum odroratum.

11. Medicugo satira, L., Mlfalfa, Bulletin :2, Colorado Station; Bulletin 15, Illinois Station; Bulletin 20, Mississippi Station; U.S. Department of Agriculture Bulletiu 31; Kansas Report, 1895.

12. Trifolium pratense.

13. Trifolium incomatum, Crimson or Scarlet Clover, Bulletin 16, Delaware Station; Report 89, Maryland Station; Annual Report 1889, Mississippi Station; Bulletin 44, Virginia Station.

14. Trifolim hylridum. Alsike Clover, Report 89, Maryland Station; Anmual Report 1859, Mississippi Station; Bulletin 15, Illinois Station.

15. Trifolium repens.

\section{THE AGRICULTURAL INSTITUTE OF THE UNIVERSTTY OF GÖTTINGEN.}

By F. W. WOLL,

Aswistent Professor of Agricultural Chemistry, Lniersity of Wisconsin.

This instetution in one of the olders and forromost of its kind in Geremany. It is perhaps hottor known amomg Imerieam experiment sta-

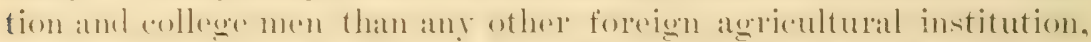
on areoumt of the high rhatater of investigational work which hats

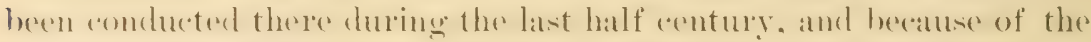
many Amerieans who have studied in (röttingen during this times.

\section{HISTORY.}

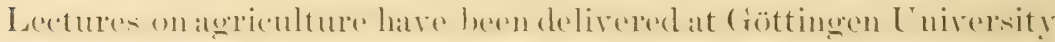

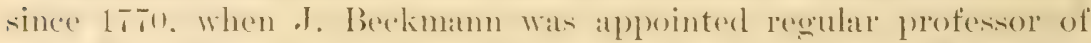
anderulture in the miversity. Ite lectured on the subject of acriculture every summer until his death in 1811, and also founded an acricultural-hotanical garden to supply instructional material for his lectures. in which all fierman plants of interest agriculturally were to be grown. It is characteristic that the object of the lectures delivered Was not to oducate intending farmers, hut " to give an insight in farm operations to studenti who. later on in public service. would be called upon to represent economic interests."

With some interruptions, the lectures were continued until 1.5.5. In that year a special agricultural course of instruction was arranged 


\section{5}

for at the miversity, thiough the efforts of the political reomomint,

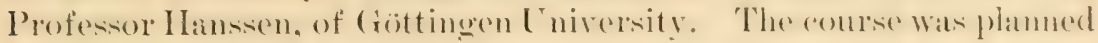
to last four semesters and was placed under the immediate ehatege of an agricultural faculty compored of four profosors, amomg whom were Wöhler. the famous chemist, and (iripenkerl. who motil his

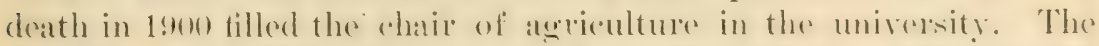
plan of study of the new course was comprehensive. Busides the

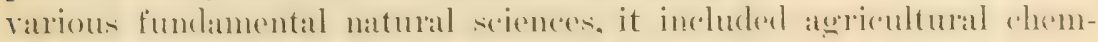
istry. veterinary seience. meteolology, agronomy, farm matnagement, forestry, politieal seienere, and rural law. The theoretical studies were to be supplemented he agricultural excursions to states in the vicinity of Göttingen: special arrangements were made hy which the latrge Govermment patate. Weende (an old monastery farm, situated about a mile north of (höttingen), conld be risited at any time for instructional purposes, and agricultural experiments ande alos be made on the land belonging to the estate.

The new course started under farorahle ansplees and received an impetus through the establishment of the Treende Experiment station in 18.5 hy the Royal Agricultural society of II:morer. (One olject in establishing the experiment station was to supplement the acricultural instruction at the university by demonstrations. “ just an if it were an organic part of the same." In 1s.5 the ofticial name of the course was changed to the Royal Agricultural Academy of GöttingenWeende, so as to give definite expression to the chose commection between the theoretical instruction oflered at the university and the pratical work at the molel Govermment farm, Weende. The atendance at the academy gradually increased from only four stulentis in 1njl to over forty in the beginning of the sixties. Alont this time the number of stulents that came to receire agricultural instruetion began to grow smaller. and there was a steady decerase during the following years, until in 1sit-i2 scarcely more than a dozen attended the academy. The cause of the decreasing attendance during the last rears of this period was not difficult to understand in view of the fact that the Agricultural Institute of Inalle Lniversity, which was estahlished in 186\%), whowed a steadily increasing attendance during the same time. The Nestor among andicultural university trachers. of ulius Kibln, through whose efforts the Halle Agricultural Institute was established, and to whom more than any other man in dare the credit for the splendid growth of agrientural unirersity instruetion, both in Gromany and in other countries, was the first one to all attention to the fact that an agricultural educational institution that is nothing but a profe-sional sehool does not supply the facilities for instruction which the times demand. Agricultural science is not merely an angeregation of applied sciences, it has its own special sphere. and in order to live and derelop it must have opportunities for veritication of prac- 
tical experiences and for inrestigation of its special prohlems-similar facilities to those long ago accorded, e. g.. to medicine. Teachers who lack this opportunity to rerify and enlarge the knowledge of the principles of agriculture can not do the hest work for their students or for their profession.

A reorganization of the Göttingen Agricultural A ademy took place during 1si-1855, to a large extent in accordance with the ideas which J. Kühn adranced and an? rocated with signal success. The new agricultural institute of the Lniversity of (röttingen (PI. XV) dates from this period. New huildings were erected, lahoratories built, the Weende Experiment station was removed to the agrieuitural institute (in 1sit). and rxperimental grounds, with garden and greenbouse, were provided for. Later changes made hare heen comparatively few, and only one of greater importance, viz, the recent establishment of an agricultural-bacteriologieal institute. the first one of its kind in the world. so far as is known.

The atrendance at the institute during late years, according to the published university atalogue, has been about 30. A number of special students, however, take single lectures or special laboratory work in the institute without being registered as agrieultural students, so that the actual number of students attending lectures of profesiors or working in the laboratories of the institute is somewhat greater than the figure given, but is at any rate small compared witl the attendance in acricultural educational institutions of similar standing in this country.

\section{PRESENT ORGANIZATION.}

The (röttingen Agrieultural Institute, as organized at present, is composed of six different departments, viz:

(1) Creneral agriculture and animal husbandry, in eharge of the director of the institute, Prof. W. Fleisehmann.

() Acricultural ehemical laboratery of the university. Prof. B. 'Tollens.

(3) Agricultural experimental grounds, Prof. C'. ron Seelhorst.

(t) Animal physiologieal experiment station. Prof. Franz Lehmamn.

(i) The veterinary institute of the university. Prof. H. J. Esiser.

(6) The agrieultural hacteriologieal institute of the university. Prof. Alfred Koch.

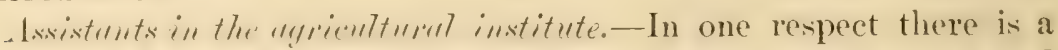
marked difference between the Göttingen Agricultural Institute and Station and our Ameriean colleger and stations, viz, the abundant help, skilled or otherwive, arailable for the routine work to be done. The janitor's of the European stations do a large amount of semichemical work and render valuable service in many ways that those in Ameriea are never called upon to do; the assistants or division heads have in 


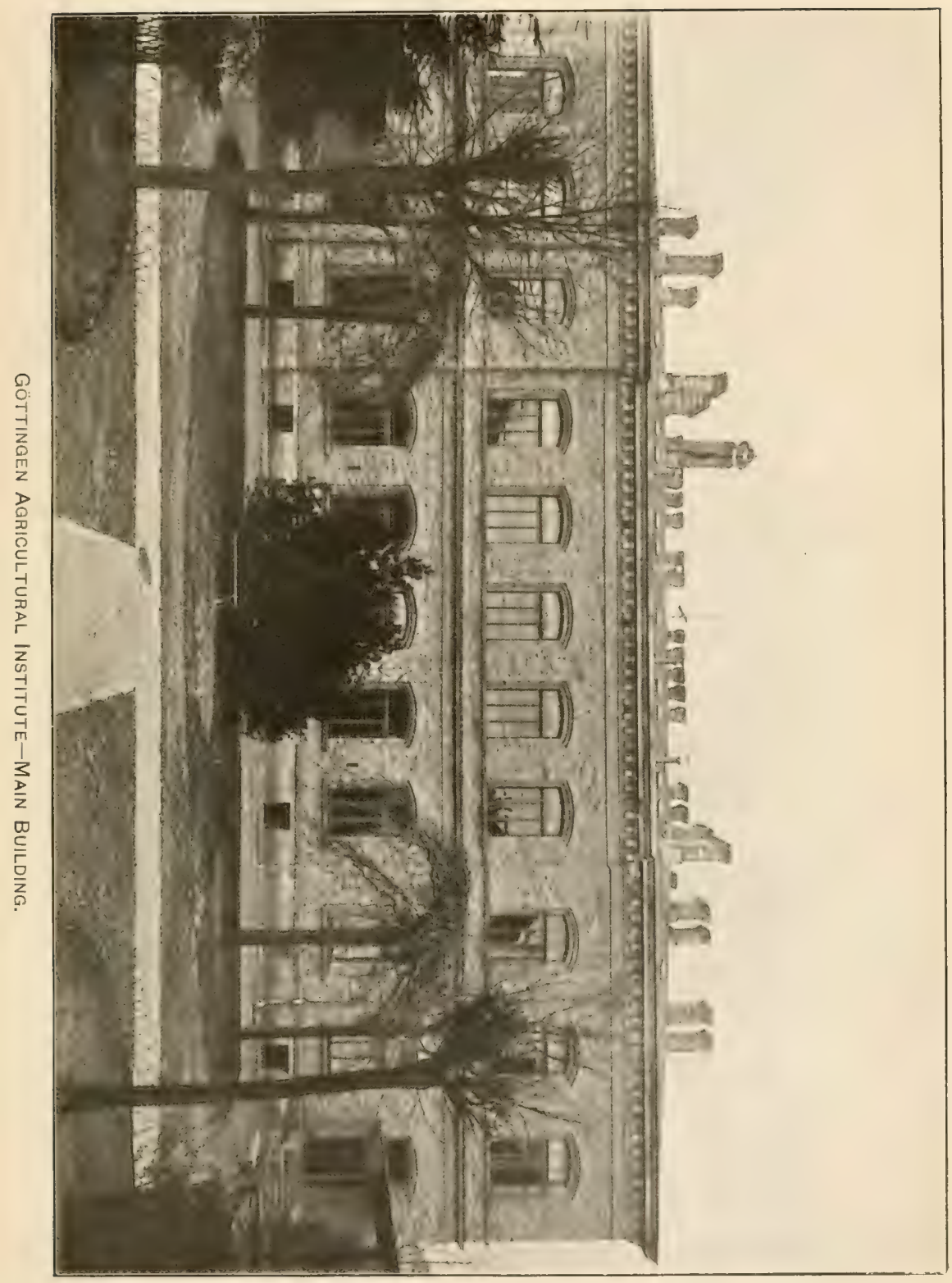



general complete ehatree of all routine work in their respective departments. such as laboratory instruction and the preparation of demonstration material for lectures. thus enahling the director or profesisor to devote nearly his molivided time and energies to work of a higher grade and to his own studies. The following statement gives the number of as-istants and janitorsor makilled laborers. in the (röttingen Agricultural Institute during the season of 1901:

Departments.

Assistants. Janitors or laborers.

Dairy laboratory

Agricultural chemical laboratory

Plant culture station

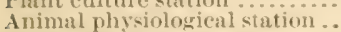

Veterimary leyartment

Agricultural bacteriological institute

Tital ...

\begin{tabular}{rrr}
1 & $\mathbf{1}$ \\
1 & 1 \\
3 & 49 \\
3 & 2 \\
1 & 1 \\
1 & 1 \\
\hline 101 & $1 . \overline{1.5}$
\end{tabular}

"Three in winter.

bxine in winter.

IEEQIREMENTS FOR ADMISSION.

To be admitted ats a student in the agricultural institute, ats in all other departments of the miversity, one must go through the formality of matriculation. (remums are matriculated when they are graduates of a gymmasium (high school) or have a similar preliminary education. while for foreigners a diploma from a recognized college or university is required. Some latitude as to preliminary education required is allowed in admitting agricultural students, and older farmers. as well ats others who wish to attend lectures, may be admitted ats Hospitanten or Hörer (special students) almost without regard to previous training. Sereral years of pratical farm work are considered highly desirable, and students are urged to come to the university so equipped, but previous training in this line is not required. A rery large proportion of the agricultural students are the sons of more or less well-to-do farmer's, who have taken part in the farm work when their school studies allowed it, and who expect to return to the home farm on the sucessful completion of their university work: other's expect to seek positions as foremen on large estates. or as teachers in the lower agricultural schools.

\section{COURSE OF STUDY.}

There is no rigid course of study offered in the agricultural institute, nor is the cluration of the course at all fixed: it is expected that the required studies ean be finished in five or six semesters, but it depends on the student himself whether or not he will present himself for examinations after this time. The following studies are recpuired in the agricultural course as arranged at the present: History of agriculture: plant producton. horticulture. plant diceases: anmal hus- 
handry-breeding, rearing, and freding of horses, eattle, sheep, swine, and poultry; reterinary science: agricultural physics-drainage. irrigation, survering, agricultural machinery and apparatus, farm huildings: farm mangement and farm hookkeeping. In addition to these professional studies the following fundamental sciences are reyuired: (hemistry (general, industrial, agricultural), physice. botany (oneral. systematice physological). hacteria and yeasts, zoology. genlogy and mineralogy, meteorology, political economy, and rural law. The instruction is imparted hy means of lectures, lahoratory work, demonstrations, excursions, and seminars.

()wing to the fact that many of the agricultural students have a limited previous traning. the lectures offered in the agricultural institute

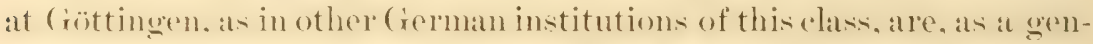
eral rule. quite clementary. It is well for American students intending to study in Europe to bear this in mind, ats it will sare them from disappointment later on. The information convered in al course of lecetures which may not cover more than two or three hours a week for a hiof German university semester-sixteen to serentern weeks in winter and twelve to thirteen weeks in summer-must necessarily be genreal and an present only the main facts of the subject treated. And after all. the knowledge thus convered is but a small part of the benefit derived from attending such a course of lectures; of firr higher value to the yommestudent must be aomted the opportunity of heaming anguainted with a thinker, te note his methods of treatment and prenentation. and to wateh something of the enthusiatm of a seholar.

METHODS OF INSTRUCTION.

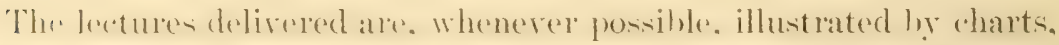
maph. musem sperimens. or simple axperiments. In the lextures on plant nutrition. for example. the whole lecture table is generally covered with sperimens of minerals, soils, soil constituents, or fertili-

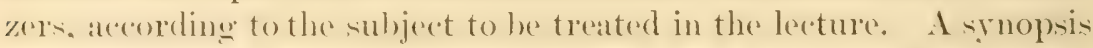
of rach lecture. or manifold copies of tables of figures and the like, to which referenere will be made in the lecture, are also furnished by some profesiors. The literature on the subject treated is also generally shown. either at the hexinning of the course or as a special topic is reateherl, and usually sent around the class for inspection, in the same way as the sperimens referext to in the lectures. Electric or other kinds of stereopticons are used at times for exhihiting pietures, (-harts, etce, on a sereen, but not to such an extent as in our betterequipped institutions, nor as sucessfully, so far at my experience goes. 


\section{INSTRUCTION IS AGRONOMI.}

The method of instruction in agronomy atephed at the (röttingen

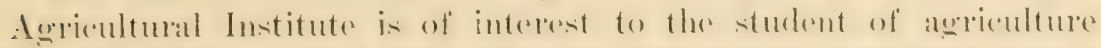
berallase of the rieh material for illustration and demonstration at hand and the excellent opportunity which the ractursions mate to the

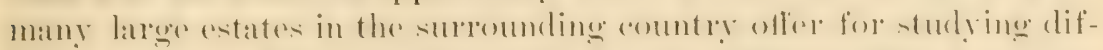

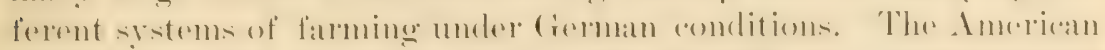
student will thed the work deme in this line full of sugegentions and directly applicable at least to bastern comblitions. The instruetion is

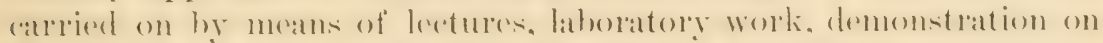

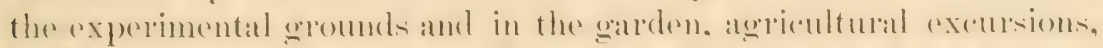

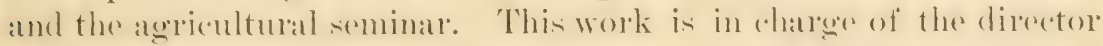

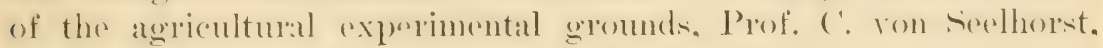
who is also professor of agronomy in the unirersity.

Lectures and laboratory work.-The courses of lectures offered in anconomy are, in the winter semester. ceneral plant production (plant life) and hreeding of agricultural crops: in the summer semester, culture of special erops. and weeds and plant disteases. The chatraceteristies of the rarious kinds of grains. roots. tulers, and ot her andicultural rops are discused in the special course. sperimens of grain

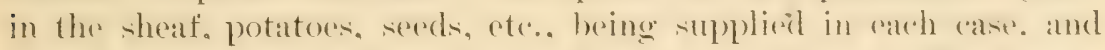
botancal charts and other illustratioe material shown. The laboratory instruetion is given throughout the year one afternom in the werek. It consists of microscopical and agricultural examinations of concentrated feeding stufls as to more important adulterations. quality, etc.: further seed tests. and. in the winter semester. studies of

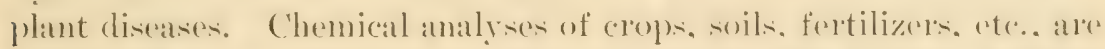
made only as required in special investigations. the general methods adopted in the lathoratory work being such as the stuclents will he likely to use and can use later on in their work on the farm.

llomenteretions.--The demonstrations on the experimental grounds. in the gatrden and the greenhouse are of special interest and value to the students. They are given once a week (Monday morning from 7 to s) during the whole year so long as there in anything of interest agriculturally to be seen outside. The writer attenirled all demonstrations giren during the summer semester of 1:m1. and wats pleated to obsere the interest which the students eridently took in the demonstrations. as well as agreatbly surprised to note the regularity with which the students met at this rather unusual hour. at regularity which was the more surprising as the attendanes at lectures. in the summer semester at least, at mont German unirersities is far from regular. The popularity of the profesers in charge douhtlesi contributed to hring ahout this result, hut not more than did the pratedical nature of the subject and the abundant material for demonstration at hand. In these demonstrations the professor wonde conduct the elasis to the 
particular part of the grounds which he wished to speak ahout, and would then explain the experiments in progress and call attention to special points of imprortance. The next and following weeks a stop) would he made at the same plats to note the development of the crop under the different conditions, differentiation of varieties or of (rops under different systems of fertilization, etc. The continuity of the demonstrations gare these talks inc reased value, the eyes of the students became trained to detect minute differences in the color or luxuriance of plants, and they could follow the gradual differentiations in plants from week to week due to different conditions of fertilization or other influenees. The effect of a seareity or an exeess of moisture: effects of hail on different crops, and how thi'y gradually recorer. or fail to recover. from these effects: estimation of the damage done hy hail. weeds, attacks of insect, or fungur diseases: identification of these. their methods of attack and distribution, and how to combat them; estimations of rields of different cropes, ete. are some of the almost immumerable subjects which furnish a well-informed teacher material for lectures in the field. The lextures were informal talks. often interpupted hy questioning of the students as to their opinions of matters observed or to be olserved. The students would jot down in their note books. although not an frequently as desirable. fiats or sugerestions hrought out. Aside from the fact that the demonstrattions served as a convenient method of gathering a large amount of direct practicat information on farm topies. they were of great value to the studento in teathing them to use their eyes and to alpply knowledge ohtained in other disciplines. and last. But not least, served to create or maintain an interest and enthusiasm for farm matters which perhaps no other method of instrution would be likely to equal.

It might be thought that there could hardly be anything new of interesting to note or grounds but little over lo ateres in area when the demonstrations came as often as one erery week, but with the rich material arailathle, which included dozens of different plat experiments with all kinds of farm cropss. rotation experiments, fertilizer tests. pot experiments, ete. this wats not the case: on the contraly, the hour proved invariably too short to go over only the portion of the grounds planned atch time. The arrangement of the German university year is most farorable for olwerving the larger whate of the round of farm operations. The summer semester corers the time from the end of April to the hegimning of August. and the winter rementer the time from the end of October to the hegimning of March. In these two prepods nealy the whole growing periods of most farm (rops fall. and most of the important farm work. like preparation of the land in the spring: seeding of spring erains: planting of peas. beans, loot repos, and potatoes, and cultivation of the same; cutting. and curing of hay: "utting, stacking. and harvesting of small gratus, 
peas, and other erops: seruring the second repp of hay; harresting and storing of root repses and potatoes: preparing and sereding lamel to winter grains, ete. Thus a full year's attendamere at the demonstrations will bring all the main fam operations up for discuscion: it will acequaint the students with the best practiees in all cases, and will wrese them a fund of combined pratetical and theoretical knowlerlege which ("an be dawn upon for assistance throughout their lifetime.

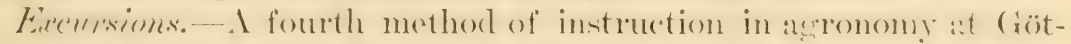
tingen Agricultural Institute is supplied by the agrieultural excursions which are made to estates in the vieinity of Göttingen one crery werek, generally saturday afternoons, but at times covering one or more days. The professor and students a re shownatound the premises by the owner, or in his absence, by his foreman, who explains the system of farming followed, the character of soil and manuring in the diflerent tields,

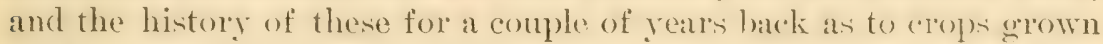
and systems of fertilization. Stables, barns, tool sheds, and of her farm buildings are also visited, and the owner's experience is ascertained in each "ase, yuestions put by the professor or any in the party being as a rule answered in an open, husinesslike way. The exenrion erenerally ends with a short social time, when light rofreshments ar"s often served, and points not previounly touched upon, or more general topies connected with the farm management, are hrotight up) and discurised. The party is apparently heartily welcome at all the places visited, the farmer's seeming to consider it an honor to receive their risitor: , in spite of the fact that the visit in some cases is a yearly or eren al halfrearly atfair. The hospitable spirit shown toward the professor and the young men who are about to enter into practical farm work themselves, is strong evidence of the high esteem in which (remman farmers hold their higher agricultural educational institutions and the men who are intrusted with the instruction of their sons or neighbors sons in their future profession.

As the excursions are under the charge of the profesisor of agronomy they are necessarily of greater benefit to students in furnishing information in this line than along the line of animal hushandry, or special dairy hushandry. In the latter subjects there is, in general, lesis to be learned in a German univerwity, ol in Germany on the whole, hy an American student, than ia almost any other branch of study, so far as the witer's experience goes.

The relations of the (rovernment estate, Weende, to the agricultural institute are somewhat different from those of the other estates visited, in so far as the renter is under contract to give agricultural students oceasional talks on the work in progress on the estate, and to allow inspection of the estate by the students at any time. The fact that the present renter of the estate, Oekonomierat Beseler, is one of the prominent gratin grower's of Crermany, who, besides being the originator of

$$
26777 \text { - No. } 127-03-6
$$


a number of improred strains of small grains, especially wheat and oats, is a progressive farmer and an excellent instructor, makes the excursions to Weenche of the highest ralue to the agricultural stuelent:The Weende estate has a total area of nite acres, of which about 480 acres of fields and meatown lie in the allurial or diluvial soil of the Leine Valley, and the rest is keuper (peecilitic) soil. To the Wrende estate belongs also the Deppoldshausen branch farm. situated on the Gö̈tingen forest plateau. abont 1,oon feet high, and :s miles distant from Weende. This farm lies in the shell-lime formation, and has a thin clay soil calling for methods of farming entirely different from those of the valley farms: it inchudes an area of stiv acres of eultivated land and $T T$ acres of pastures. The system of faming followed on estates in the vicinity of (röttingen is mostly grain raising and sugarbeet culture. but there are also a number of large dairy farms that are visited at intervals.

Seminere.-The tifth branch of the instruction in plant production in Gröttingen i. the agricultural seminar. This is held in eonjunction

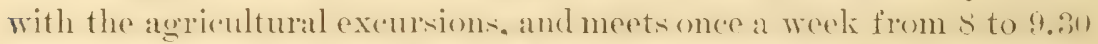

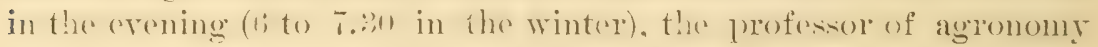
conducting the seminar. One of the students, acting as reporter on the agrientural exeursion. prepares a paper on the entate risited. which is read at the seminar. In this a full account is given of what has been seen of liarmed about the place visited, and criticioms are oflered as to faming methods. ete. The discussion following the paper lorings out important peints that were not considered in the

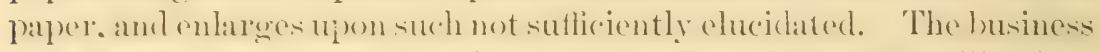
side of the farm operations, the erenomy of systems of fertilization. the staties of fertilizing ingredients in the soil, system of (crep rotation adspted, and special conditions of soil or marliets moler which the farmer workis are among the subjects likely te come up for discussion each time. The regular at temlance of the students at the seminar, and the lively discusions which generally arise as to methods of farm practice or principles underlyng these, testify to the interest which the students take in this work and the benefit which they derive from taking part in the seminar.

\section{FACIITTIES FOL INSTRUCTION.}

The facilities for work in the various departments are in general up to the refuirements of modern edueational institutions, even aceording to the standards common in this country, where, as a rule, buildings: and acpuipment have been provided for the special purpose in view, and ale not, as is often the case abroad, the adapted inheritance of rarlier times. In Ameracun student will most likely be surprised. howerer, to note the small sale on which the equipment is arranged at Gottingen, as at nearly all other German agricultural colleges. 


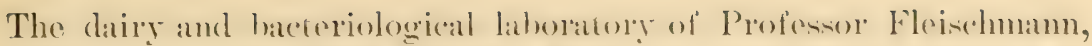
whose name is identified with the develepment of dairy serenes in all it phases from its heerimning unt il the present time. ansists of two roonis. one about 24 hy fol feet and the other 24 ly 14 fort, with alecommorlations for less than hall a doyen students. The agrientural

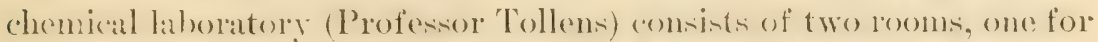

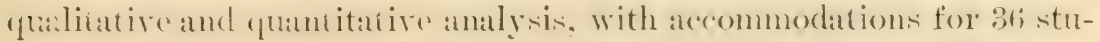
dents, and one for adraneed or thesis work, for 10 students. The gen-

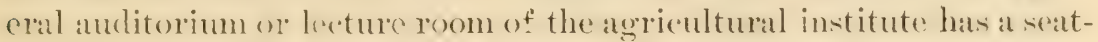
ing (alpacity of alout 36 , and is never crowded-less than ever later in the semester, owing to the German system of noncompulsory attendance.

For purposes of instruction and demonstration in agronomy use is made of the experimental grounds, greenhouse, and other equipment of the plantculture experiment station. The experimental grounds have a total ares of about 15 acres, and adjoin the agricultural institute on the north (Pl. XVI, figs. 1 and 2). Experimental work on this land was begun by Professor Drechsler in the beginning of the serenties, and has included trials of rytem of rotations, variety tests

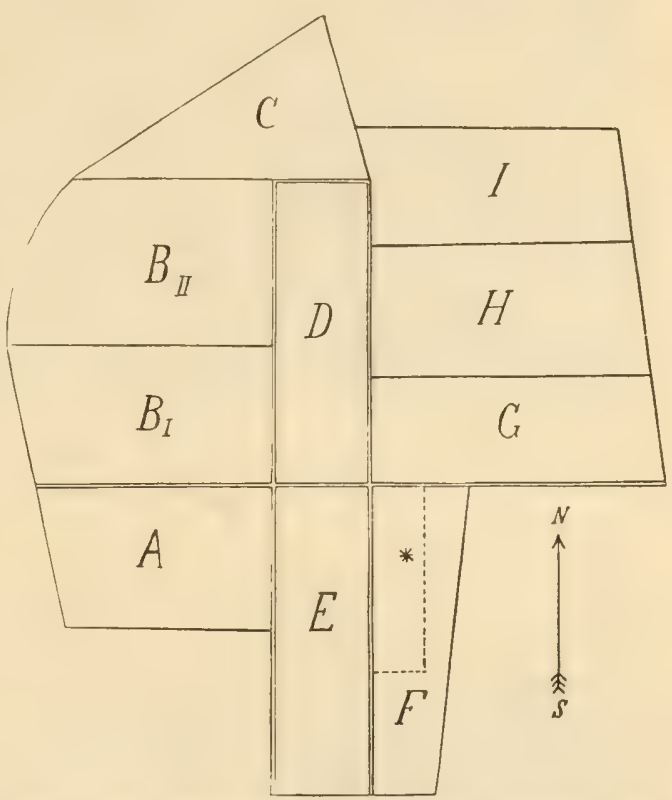

of farm crops, fertilizer experiments, and improvement of cereals and other crops through continued selection. The diagram herewith given shows the divisions of the experimental grounds (fig. 22). The crops grown on these in 1901 were as.follows:

Field A.-Göttinger rye.

Field $B$ I.-Square-head wheat.

Field B II.-Potatoes, we rarieties. Potash fertilizer experiments. Field C.-Red clover.

Field I). Peas, - varietirs, and heans. Potash fertilizer experiments.

Fi,ll E.-Rye, flax, winter wheat, mangel-wurzels, barley, beans, potatoes, spring wheat, oats, sugar beets, and potatoes. Fertilizer experiments. 
Ficld F.-Plant breeding experiments with rye, winter wheat, spring wheat, oats, sugar beets, and potatoes. Fertilizer experiments with oats and sugar beets.

Fiedd F (south of plant-hreeding plats).-Clover, tests of 30 varie. ties of different origin; spring wheat, s varieties; potatoes, hreeding experiments with 4 varieties.

Firld F (east of plant-breeding plats). - Sugar and fodder beets (experiments with different distances of planting): petatoes, 5 varieties; peas, 2 varieties.

Fichl li. ()ats, (röttinger and Beseler"s improved. with clover.

Field II.--Root crops: Sugur beets. mangel-wurzels. P'otash fertilizer experiments.

Field I.-Square-head wheat.

In the trial grarten small plats are grown of all plants of agricultural importane to northern (remany, the different kinds of grasses and fodder plants, (ereals. root (rops. small f'ruits, weeds, etc. Mixtures of grasises and legminous plants are also grown under different systems of fertilization, to study the effect or to ohtain demonstration material for showing the offeret of certain fertilizers in faroring the growth of some plants and checking that of other's. similar experiments were also conducted during the season of 1 toul in pots in the greenhouse. under liheral or seant supplies of water. in the study of the effect of water supply on the action of different fertilizers or combinations of such.

Pot experiments ane endured in the gerenhouse shown in Pl. XYII. The dimensions of the greenhouse are $2:$ by to feet, with a workrom

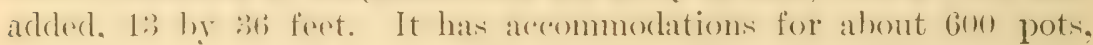
which are placed on truelis and in good weather always kept outside. The experiments are eonducted areording to the plan worked out at the I armstalt station. The ceneral problem studied during late year: in the influenere of the water stuply on the utilization of different kinds of fortilizers by apreals. grasios, and other farm crops. The laboratery imestigations are chiofly supplementary to experiments condueted in the field, garden, or greenhouse, the main work of the assistant, being the remical analysis of materials harrested, soils, fertilizer's, ote. I great cleal of independent research work has, however, alio been conducted in the laboratory, and has from time to time been published in the periodical literature, reperially in the Jommal für Landwirtschaft.

Librasy and musenm. A deseription of a (ierman agricultural institute would be incomplete without a mention of its library and musemu, hoth of which form all-important parts of the facilities for instruction and research. The library of the cröttingen Agricultural Institute is small, less than 3,000 volumes, but is rery complete in German works on agriculture and allied subjects. To an American 


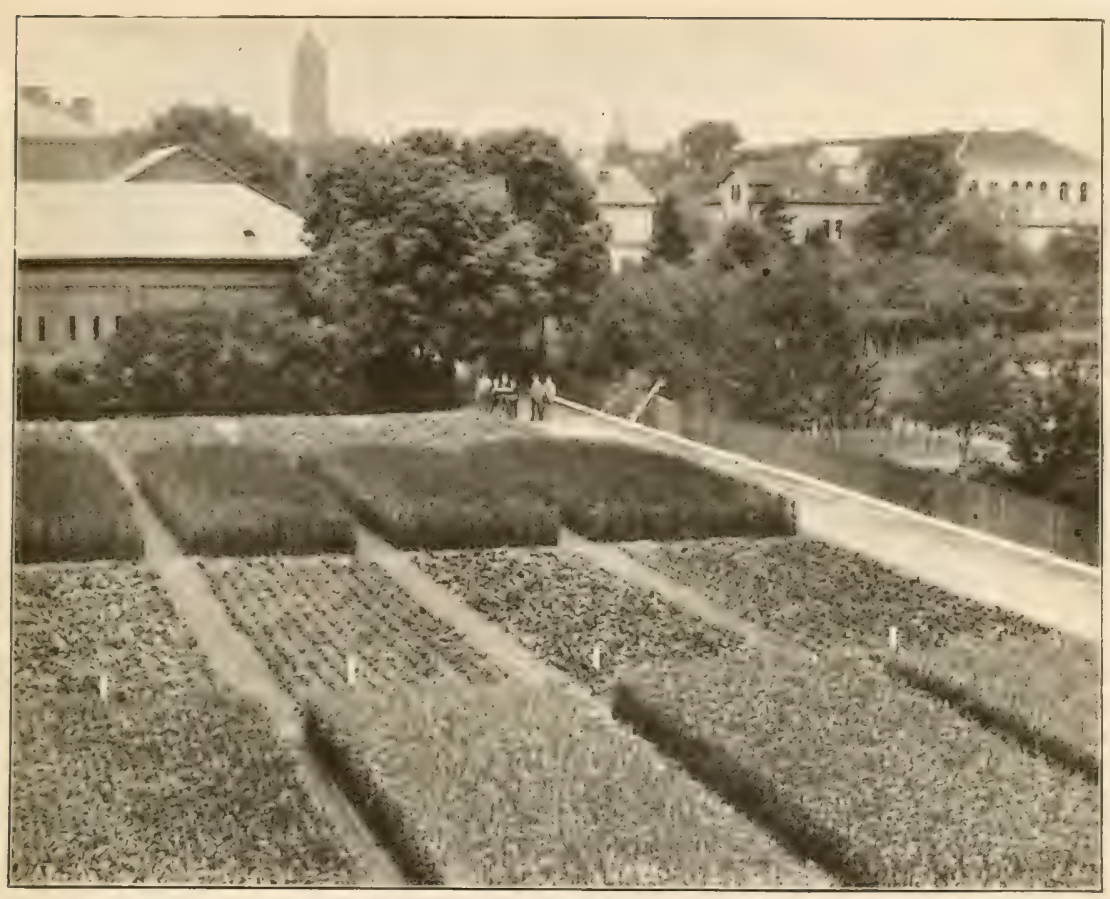

Fig. 1.-Göttingen Agricultural InStitute-LOOKIng SOUtheast.

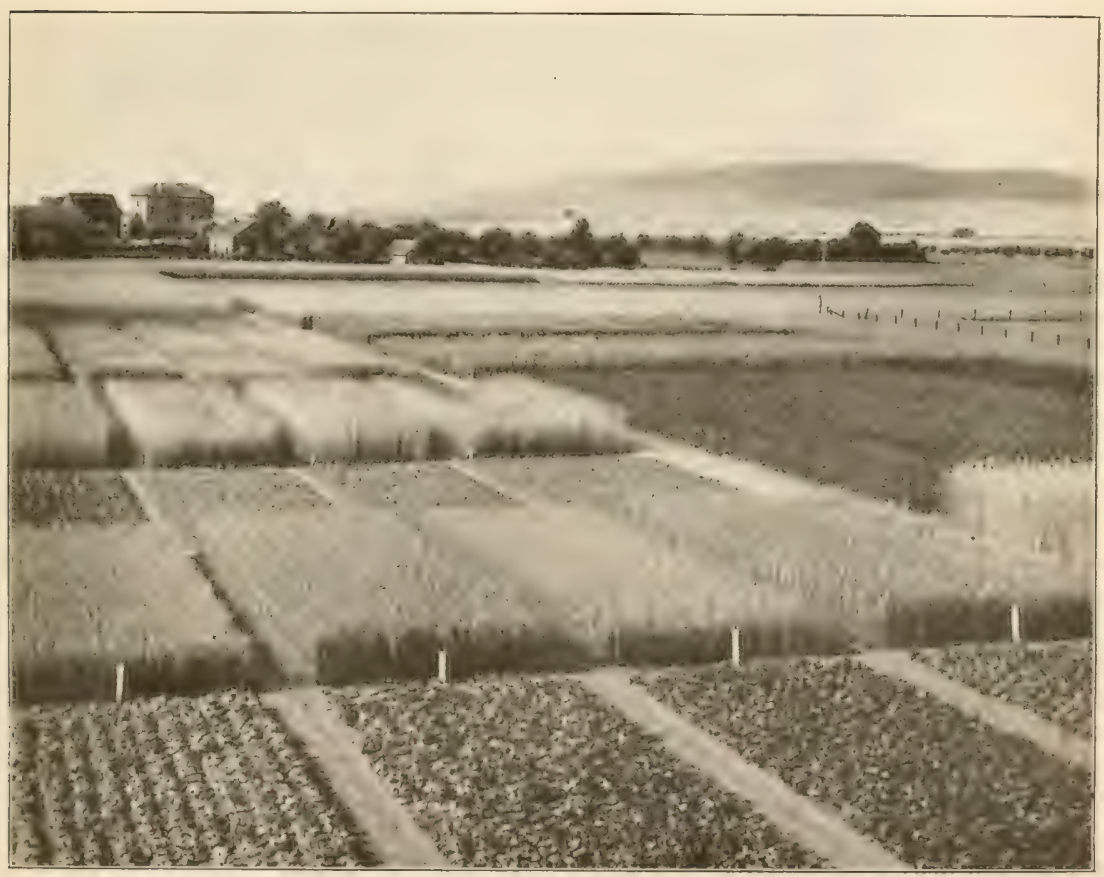

Fig. 2.-Göttingen Agricultural InStITUTE-LOOKIng NORTHEAST FROM INSTITUTE BUILDINGS ACROSS THE EXPERIMENT PLATS. 



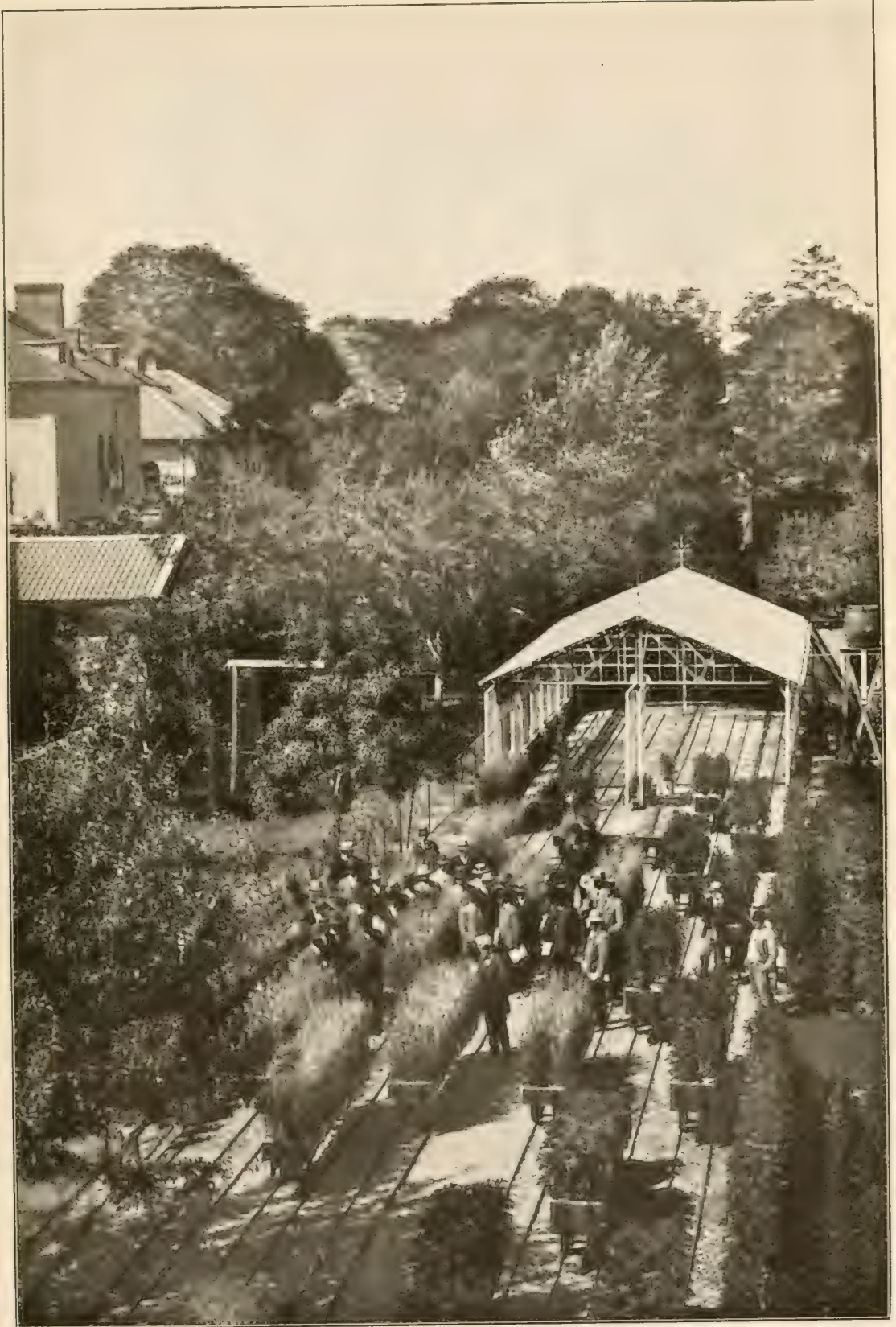

GÖTTINGEN AgRICULTURAL INSTITUTE-GREENHOUSE. 

student the absence of the best foreign (English or Americau) agricultural literature, in this library as in all other (rerman libraries with which the writer is acquainted, will seem strange. In the laboratories of the institute are found special small, but good, reference libraries, which are aceesisihle at all times and are of great selvice to sturlents. There is also a reading room, where current number's of the leading German (and other continental- Buropean) aglicultural papers and scientific magazines are kept.

The musem of the Götingen Agrienltural Institute was founded in 1., l he Profesorer (tripenkerl, and therefore represents half a con-

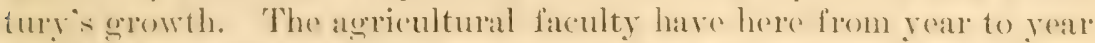
deposited collextions in their respective lines of instruction and investigation. with the view of making it valuable for instructional purposes lather than of establishing an agricultural muscum. "The collection of levding stuffs contains samples of feeds used by Ifemeherg in his fundimental studies on the nutrition of farm animals, and numerous other specimens in the museum hear testimony of investigations conducted at Göttingen during the latter half of the nineteenth century. The rich collections thus accumulated form invaluable material for demonstration and are constantly utilized by the professor's in their lectures. 
LE Mr ${ }^{\prime} 07$ 






. 


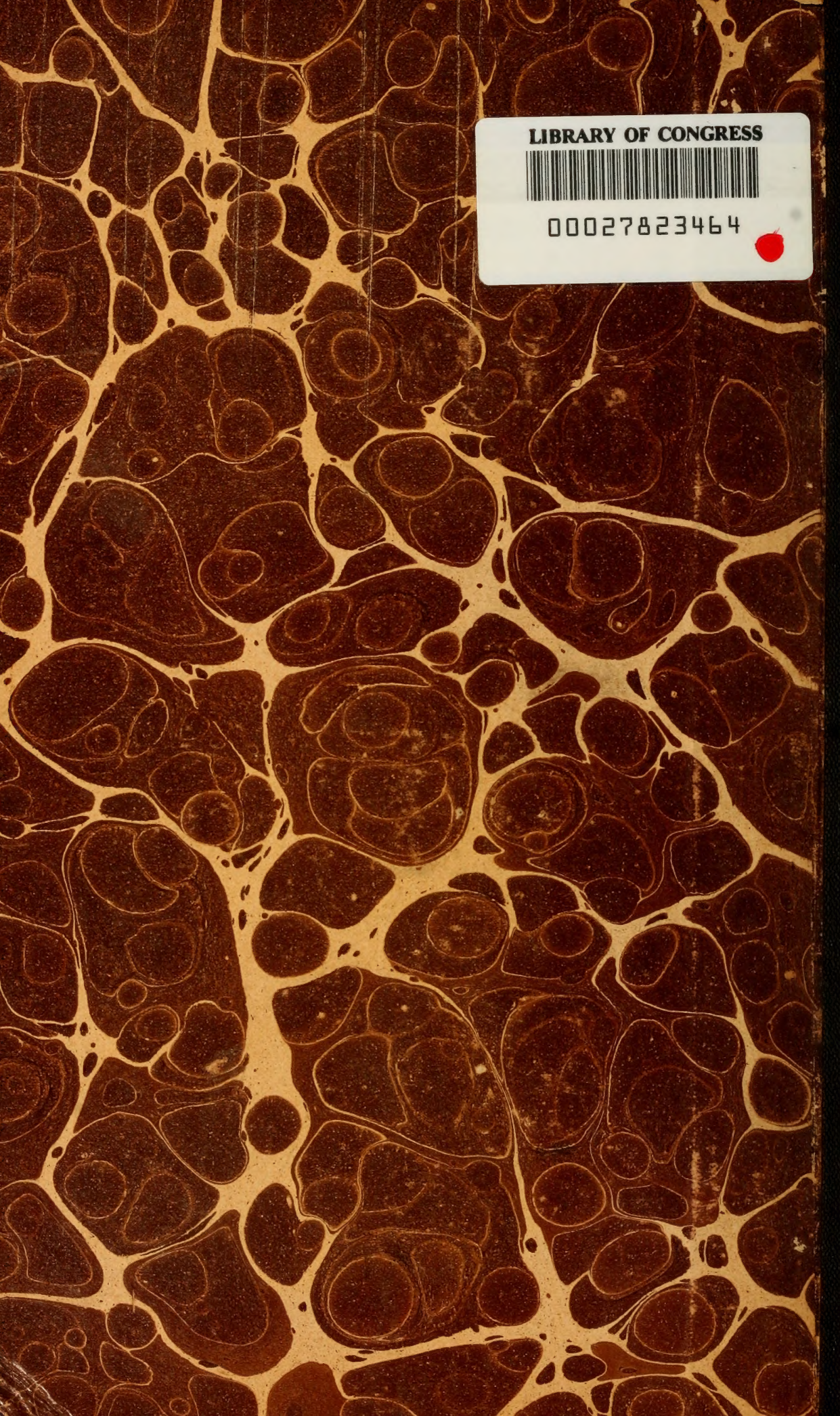

